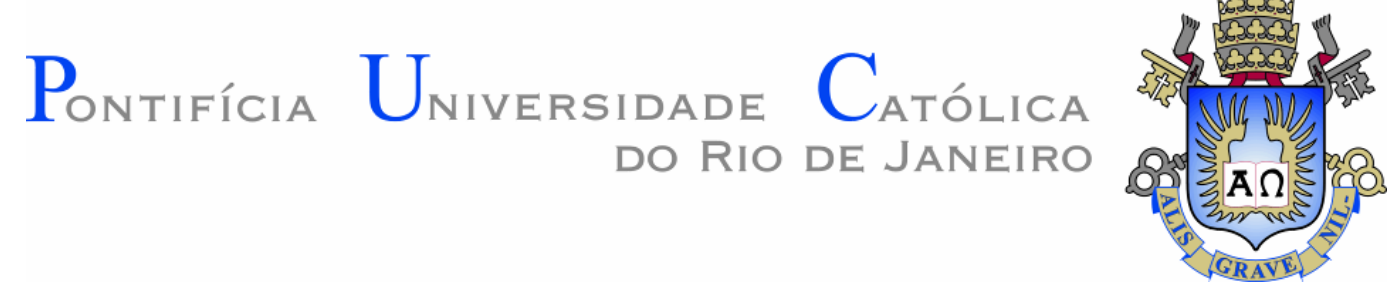

Yasmin Leonardos Haddad

BERGSON E A METAFÍSICA DO MOVENTE

Dissertação de Mestrado

Dissertação apresentada ao programa de PósGraduação em Filosofia da PUC-Rio como requisito parcial para obtenção do grau em Mestre em Filosofia.

Orientador: Prof. Pedro Duarte de Andrade 


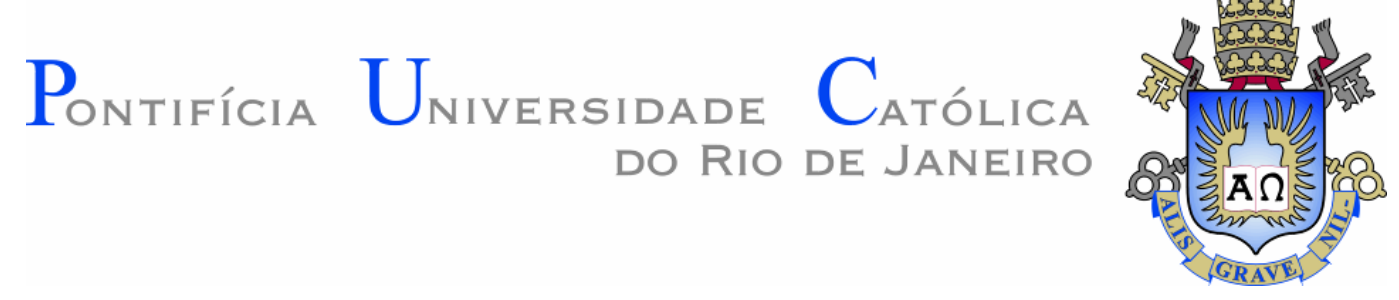

Yasmin Leonardos Haddad

\title{
BERGSON E A METAFÍSICA DO MOVENTE
}

Dissertação apresentada como requisito parcial para a obtenção do grau de Mestre pelo Programa de PósGraduação em Filosofia do Departamento de Filosofia do Centro de Teologia e Ciências Humanas da PUC-Rio. Aprovada pela Comissão Examinadora abaixo assinada.

\author{
Prof. Pedro Duarte de Andrade \\ Orientador \\ Departamento de Filosofia - PUC-Rio \\ Prof. Maxime Rovere \\ Departamento de Filosofia - PUC-Rio
}

Prof. Ulysses Pinheiro

IFCS - UFRJ

Profa. Monah Winograd

Coordenadora Setorial do Centro de Teologia e Ciências Humanas - PUC-Rio 
Todos os direitos reservados. É proibida a reprodução total ou parcial do trabalho sem autorização da universidade, da autora e do orientador.

\section{Yasmin Leonardos Haddad}

Graduou-se em Filosofia pela UFRJ (Universidade Federal do Rio de Janeiro) em 2014. Tem como interesses principais Filosofia Francesa Contemporânea e estuda a obra do filósofo Henri Bergson. Os principais temas investigados são a questão do tempo e do conhecimento do real, assim como a relação entre conceitos e intuição. Interessa-se também pelas questões referentes à Teoria da Evolução e sua articulação com questões filosóficas, mais especificamente propondo um diálogo entre as obras de Henri Bergson e Georges Canguilhem.

Ficha Catalográfica

Haddad, Yasmin Leonardos

Bergson e a metafísica do movente / Yasmin Leonardos Haddad ; orientador: Pedro Duarte de Andrade. - 2017.

$89 \mathrm{f.} ; 30 \mathrm{~cm}$

Dissertação (mestrado)-Pontifícia Universidade Católica do Rio de Janeiro, Departamento de Filosofia, 2017.

Inclui bibliografia

1. Filosofia - Teses. 2. Bergson. 3. Duração. 4. Metafísica. 5. Movente. 6. Real. I. Andrade, Pedro Duarte de. II. Pontifícia Universidade Católica do Rio de Janeiro. Departamento de Filosofia. III. Título. 


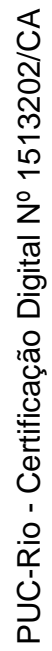

À Julie 


\section{Agradecimentos}

Ao Caio, por ser meu grande companheiro, pela confiança, pelo apoio incondicional, pelo seu carinho e pela sua música, principalmente.

À minha família pelo incentivo, pela força. À minha mãe, Ana, pelo apoio intelectual, e à minha avó Cyrene, por ser um exemplo de mulher em quem me espelho. Ao meu pai, Sami, pelas corridas juntos, ao Théo, meu irmão, pelo incentivo, ao meu avô, Tomaz, meu maior exemplo e admiração. Obrigada a todos por terem sido meus companheiros nesse trajeto.

Aos meus amigos, nada teria sido possível sem vocês. Obrigada pelo carinho, pelos abraços e pela compreensão, tanto nos momentos em que estive presente e nos que estive ausente escrevendo. Obrigada Yannick, Laeticia, Juliette, Déborah, Kaenne, Carô, Carlota e Felipe R., João, Fabi, Felipe E. e Raul. Ao Pedro Bonfim pela sua atenta revisão e pelas conversas sobre Bergson. Obrigada Julie, pelo seu interesse profundo na duração e por me mostrar que existe um tempo outro, distante, porém onipresente.

Aos meus professores: Pedro, por ter sido um orientador tão atento e cuidadoso, pelo apoio moral e intelectual, Maxime, pela amizade e pelo olhar detalhista sobre meu caminho, Déborah, pela sua participação em várias etapas do mestrado, pela ajuda na qualificação e pelas aulas que tive o prazer de assistir. Ao Ulysses por ter me orientado na graduação e aceitar participar da defesa. Agradeço ao departamento de filosofia da PUC-Rio por ter sido uma parte tão importante da minha educação. Ao IFCS e à UFRJ pela minha formação em Filosofia. Agradeço à FAPERJ pela bolsa concedida. 


\section{Resumo}

Haddad, Yasmin Leonardos; Andrade, Pedro Duarte de. Bergson e a metafísica do movente. Rio de Janeiro, 2017. 89p. Dissertação de Mestrado Departamento de Filosofia, Pontifícia Universidade Católica do Rio de Janeiro.

A compreensão de um tempo puro, independente dos moldes do espaço, é o principal problema investigado pela filosofia de Henri Bergson. Para chegar à realidade da duração, a investigação encontra diversos obstáculos criados pela posição de falsos problemas, sendo o principal deles a confusão comum entre tempo e espaço. Uma das consequências desta compreensão de tempo é a formulação de que a realidade é mudança constante, fluxo contínuo. A partir dessa tese, tentaremos abordar a possibilidade de conhecimento de um real cuja característica central é mudar. Em uma tentativa de reverter esses falsos problemas, principalmente por meio da crítica de ilusões causadas pelo senso comum, tentaremos demonstrar como é possível uma compreensão do tempo em cada uma de suas dimensões - presente, passado e por vir - na medida em que a sua realidade é uma continuidade dessas três dimensões. As três ilusões que investigaremos são: a ilusão da simultaneidade, a ilusão de uma localização física da lembrança e a ilusão da causalidade. Nossa hipótese interpretativa é a de que na compreensão de cada uma dessas ilusões e em contraponto a elas, torna-se possível acessar a realidade do presente, do passado e do por vir, respectivamente, e formular uma metafísica do movente que é o fundamento de um conhecimento verdadeiro acerca da realidade do tempo.

\section{Palavras-chave}

Duração; metafísica; movente; Bergson. 


\section{Résumé}

Haddad, Yasmin Leonardos; Andrade, Pedro Duarte de (directeur de thèse).

Bergson et la métaphysique du mouvant. Rio de Janeiro, 2017. 89p. Dissertação de Mestrado - Departamento de Filosofia, Pontifícia Universidade Católica do Rio de Janeiro.

La compréhension du temps pur et indépendant de l'espace est le principal problème investigué dans la philosophie d'Henri Bergson. Pour rejoindre la réalité de la durée, l'investigation rencontre des obstacles divers crées par la position de faux problèmes, dont le principal est celui de la confusion entre temps et espace. Une des conséquences de cette compréhension du temps est la formulation que la réalité est le changement constant, flux continu. En partant de cette thèse, nous essayerons de comprendre la possibilité d'une connaissance du réel dont la caractéristique centrale est le changement continu. En une tentative de reposer ces faux problèmes, principalement par la critique à des illusions causées par le sens commun, nous essayerons de démontrer comment une compréhension du temps pur est possible en chacune de ses dimensions - présent, passé et avenir - dans la mesure où sa réalité est une continuité entre ces trois dimensions. Les trois illusions que nous proposons d'investiguer sont la l'illusion de la simultanéité, l'illusion d'une localisation physique du souvenir et l'illusion de la causalité. Notre hypothèse interprétative est que dans la compréhension de chacune de ces illusions et en s'opposant à elles, l'accès à la réalité du présent, du passé et de l'avenir, respectivement, devient possible, ainsi que la formulation d'une métaphysique du mouvant qui est le fondement d'une connaissance vraie sur la réalité du temps.

\section{Mots-clés}

Durée; métaphysique; mouvant; Bergson. 


\section{Sumário}

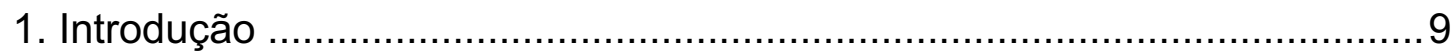

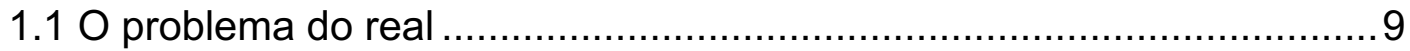

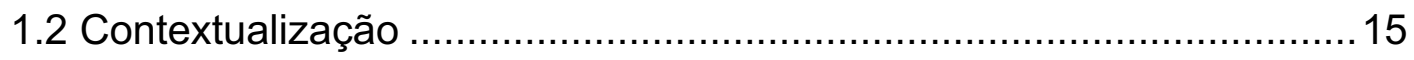

1.2.1 A crítica a uma concepção espacializada do tempo ......................15

1.1.2 O "conceito" de duração ............................................................. 18

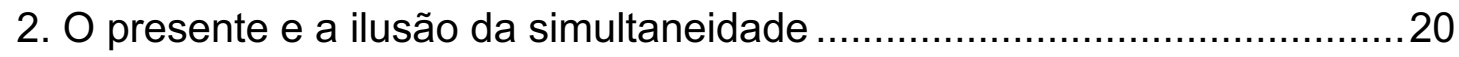

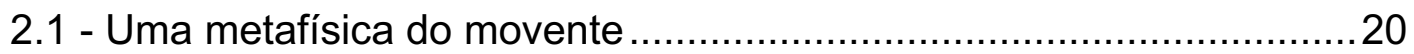

2.1.1 Tempo heterogêneo x espaço homogêneo ..................................24

2.1.2 Percepção da mudança e conhecimento da mudança .....................31

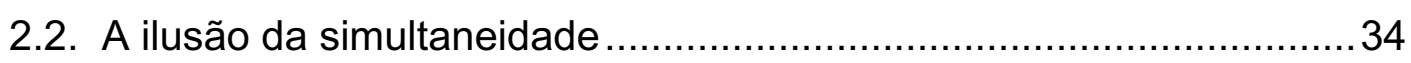

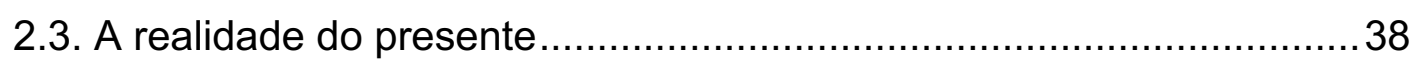

2.3.1 O presente e os "dados imediatos" ................................................ 38

2.3.2 Simultaneidade e realidade do presente.......................................39

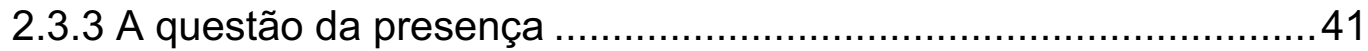

3. O passado e a ilusão de uma localização física da lembrança...................43

3.1 Considerações sobre o conceito de imagem .................................... 44

3.1.1 O cérebro como imagem central .............................................. 47

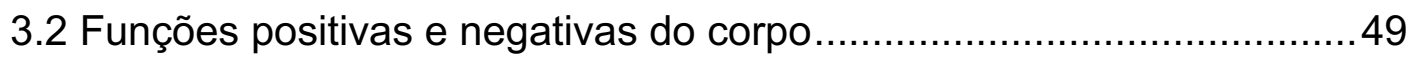

3.3 Memória e duração: a realidade do passado .....................................52

3.3.1 Memória, lembrança e hábito: as duas formas da memória ...........52

3.3.2 O exemplo do aprendizado de uma lição:......................................53

3.3.3 Memória-hábito e memória-lembrança ........................................55

3.3.4 Sobre o caráter não-físico da lembrança ......................................56

3.3.5 Imaterialidade da lembrança e a existência de um passado puro .59

3.3.6 A realidade do passado e sua coexistência com o presente .........61

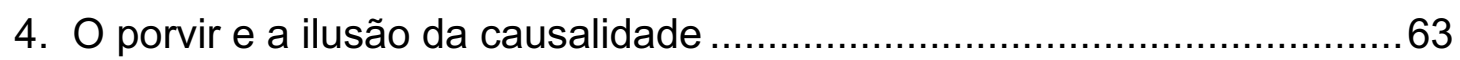

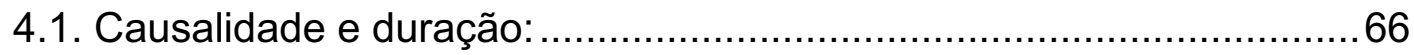

4.2. A ilusão da causalidade no contexto da evolução: ................................68

4.2.1. Perspectivas biológicas da evolução .........................................69

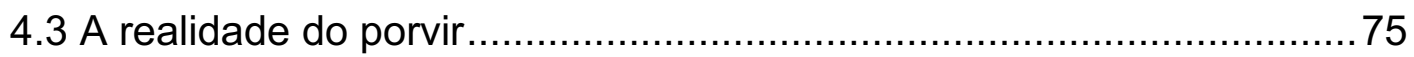

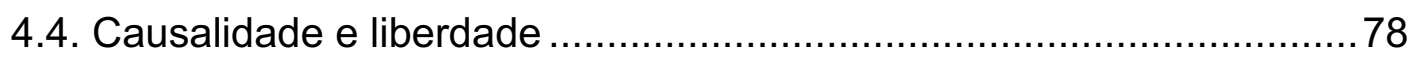




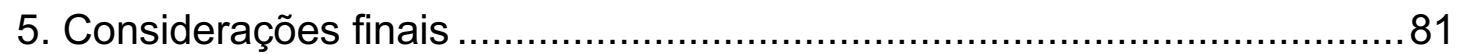

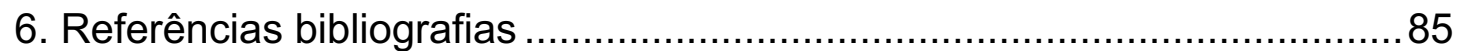




\section{Introdução}

\section{1}

\section{O problema do real}

Em O pensamento e o movente, coletânea de ensaios organizada por Henri Bergson para reunir os principais conceitos de seu pensamento ${ }^{1}$ publicada em 1934, encontramos a seguinte formulação: o real "não são os 'estados' simples, instantâneos, tomados por nós, mais uma vez, ao longo da mudança; é, ao contrário, o fluxo, a transição, a mudança ela mesma"”2 (BERGSON, 2013 p. 7, tradução nossa). Encontramos aqui uma oposição entre o que é instantâneo, compreendido "ao longo" da mudança, e a mudança ela mesma. Essa oposição resulta na crítica a uma concepção da mudança baseada no espaço, isto é, a mudança distribuída ao longo de um tempo infinitamente divisível (e nesse caso a mudança requer um substrato sobre o qual essa mudança atua). Conceber a mudança como "ela mesma" significa pensá-la em termos temporais apenas. Nesse caso, não é preciso que algo permaneça ou subsista a essa mudança, já que ela é total. O problema central da filosofia de Bergson, isto é, o de uma compreensão do tempo fora dos moldes do espaço, encontra-se, de forma sintética, nessa definição de real.

A mudança percebida por nós só pode ser compreendida na medida em que o tempo é pensado como uma sucessão de instantes. Mas pensar o tempo como sucessão, desde a filosofia grega, resulta em paradoxos, como por exemplo, os paradoxos de Zenão. Bergson lança mão desses paradoxos para exemplificar as consequências de uma concepção do tempo a partir do espaço, ou seja, de um tempo divisível infinitamente em segmentos. No paradoxo de Aquiles e da tartaruga, ambos apostam uma corrida em que é dada uma vantagem para a tartaruga que, por ser consideravelmente mais lenta que Aquiles, deve perder a

\footnotetext{
${ }^{1}$ Ils [les essais] portent principalement sur la méthode que nous croyons devoir recommander au philosophe. Remonter à l'origine de cette méthode, définir la direction qu'elle imprime à la recherche, tel est particulièrement l'objet des deux essais composant l'introduction.

${ }^{2}$ Ce qui est réel, ce ne sont pas les «états », simples, instantanés pris par nous, encore une fois, le long du changement; c'est au contraire le flux, c'est la continuité de transition, c'est le changement lui-même.
} 
corrida, apesar da vantagem conferida a ela. O paradoxo consiste então em notar que, para que Aquiles possa alcançar a tartaruga, ele sempre precisaria percorrer metade da distância percorrida pela tartaruga antes de alcançar a distância total percorrida por ela e, sendo assim, sempre estaria um pouco atrás da tartaruga, que ganharia então a corrida contra Aquiles. Bergson propõe que a tartaruga só é vencedora na corrida contra Aquiles porque o problema foi formulado em termos espaciais, e não temporais. Dividir o espaço em segmentos (por exemplo, metade da distância percorrida pela tartaruga, em seguida a metade da metade, e assim por diante) é possível. O erro, no entanto, é quando tentamos transpor essa divisão feita no espaço percorrido para o tempo, assumindo que é possível uma analogia entre a divisão do espaço e a divisão do tempo. Isso ocorre pois há uma confusão entre tempo e espaço, na medida em que o trajeto percorrido pela tartaruga é o mesmo de Aquiles, embora o tempo de percurso seja diferente para cada um.

Segundo Bergson, o paradoxo resulta de um misto entre tempo e espaço: assume-se que o mesmo espaço entre os corredores é dotado de uma mesma quantidade de tempo, divisível infinitamente. Isto é falso, pois, na realidade, apenas o espaço percorrido pode ser divisível infinitamente, ou seja, traduzido em quantidades. Já o tempo real, sem a interposição de parâmetros espaciais, possui outra natureza, intensiva em oposição à natureza extensiva do espaço.

Porque Aquiles ultrapassa a tartaruga? Porque cada um dos passos de Aquiles e cada um dos passos da tartaruga são indivisíveis enquanto movimentos, e grandezas diferentes enquanto espaço: de modo que a adição não demorará a resultar, para o espaço percorrido por Aquiles, em uma distância superior ao espaço percorrido pela tartaruga e a vantagem que ela tinha sobre ele. É o que Zenão não leva em conta quando recompõe o movimento de Aquiles segundo a mesma lei do movimento da tartaruga, esquecendo que apenas o espaço se presta a um modo de decomposição e de recomposição arbitrária, confundindo assim espaço e movimento ${ }^{3}$ (BERGSON, 2013a, p. 84, tradução nossa).

Por outro lado, se pensarmos em termos temporais, podemos compreender a mudança em sua própria condição, ou seja, como fluxo puro, sem necessidade de se conceber um substrato sobre o qual a mudança aconteceria. A própria

\footnotetext{
${ }^{3}$ Pourquoi Achille dépasse-t-il la tortue ? Parce que chacun des pas d'Achilles et chacun des pas de la tortue sont des indivisibles en tant que mouvements, et des grandeurs différentes en tant qu'espace : de sorte que l'addition ne tardera pas à donner, pour l'espace parcouru par Achille, une longueur supérieure à la somme de l'espace parcouru par la tortue et de l'avance qu'elle avait sur lui. C'est de quoi Zénon ne tient nul compte quand il recompose le mouvement d'Achille selon la même loi que le mouvement de la tortue, oubliant que l'espace seul se prête à un mode de décomposition et de recomposition arbitraire, et confondant ainsi espace et mouvement.
} 
linguagem, para Bergson, opera usualmente a partir de termos espaciais, o que dificulta uma possível aproximação do cerne dessa mudança. Bergson já enuncia essa tese nas primeiras linhas do prefácio ao Ensaio sobre os dados imediatos da consciência:

Exprimimo-nos necessariamente por palavras e pensamos quase sempre no espaço. Isto é, a linguagem exige que estabeleçamos entre as nossas ideias as mesmas distinções nítidas e precisas, a mesma descontinuidade que entre os objetos materiais (BERGSON, 1988, p. 9).

O problema do real que pretendemos abordar se insere justamente no ponto de partida dessa definição: como é possível conhecer o real sendo ele fluxo, mudança contínua? A partir de uma crítica a uma concepção espacializada do tempo, isto é, à ideia de que o tempo, assim como o espaço, pode ser divisível infinitamente, Bergson introduz uma diferença de natureza ${ }^{4}$ entre o mundo material, existente no espaço, e a consciência, existente na duração, compreensão esta que é apresentada no Ensaio sobre os dados imediatos da consciência.

Embora o conhecimento seja possível justamente porque existe uma consciência, a cisão entre duração e espaço parece criar dualismos que dificultam a nossa possibilidade de conhecimento do real. Esses dualismos decorrem diretamente dessa nítida distinção entre o que ocorre no espaço, externo à consciência, e o que ocorre no tempo, na consciência. Muitas vezes, nos textos de Bergson, esses dois ambientes são vistos como distintos, possibilitando então a ideia de que haja um mundo da consciência do sujeito e o mundo "fora de nós".

Isso dificulta o conhecimento no sentindo que esses dois registros diferem em natureza, e não em grau, o que é problemático na compreensão da relação entre o sujeito e o mundo no qual ele se encontra. Essa distinção entre consciência (duração) e espaço é, em nossa hipótese interpretativa, mais radical no Ensaio sobre os dados da consciência, primeira obra publicada de Bergson, mas parece se diluir ao longo dos livros que seguem. Trata-se de um recurso didático que introduz essa cisão para instaurar uma diferença radical entre tempo e

\footnotetext{
${ }^{4}$ Diferenças de natureza se opõem, no contexto bergsoniano, às diferenças de grau. O que difere em grau é aquilo que pode ser pensado em termos quantitativos, isto é, uma diferença numérica. $\mathrm{O}$ que difere em natureza não pode ser comparado numericamente, pois a cada diferença trata-se de um novo elemento, incomparável ao anterior ou ao posterior. Segundo Bergson, uma das fontes de imprecisão na filosofia é a falha em identificar as diferenças de natureza onde o senso comum apenas percebe diferenças de grau. Em outros termos, diferenças de natureza são diferenças qualitativas e diferenças de grau são diferenças quantitativas.
} 
espaço por meio da analogia entre uma consciência que dura e aquilo que existe fora dela, no espaço.

O que pretendemos mostrar é como a crítica a uma concepção espacializada do tempo pode ser pensada a partir de três temas distintos, porém relacionáveis, coincidindo com a crítica a três ilusões ${ }^{5}$ apontadas por Bergson em diferentes momentos de sua obra. Tais ilusões, nos mantendo em uma confusão entre tempo e espaço, nos velam o acesso direto ao real.

Em Ensaio sobre os dados imediatos da consciência, analisaremos a crítica à ilusão da simultaneidade ${ }^{6}$ que é também uma crítica à uma mácompreensão do movimento. Compreende-se por simultaneidade uma interseção entre tempo e espaço, isto é, a existência de dois acontecimentos que ocorrem no mesmo instante. Essa crítica é o resultado direto do que Bergson chama de uma confusão entre movimento percorrido e o tempo, conforme exemplificado no paradoxo de Zenão (Aquiles e a tartaruga) e resultará, por conseguinte, em antecipar que a simultaneidade é uma ilusão pois a noção de instante não pode existir quando o tempo é considerado independentemente dos moldes do espaço, isto é, como duração. Essa análise se torna possível na medida em que uma diferença fundamental se destaca entre o tempo puro e o movimento, que é equivocadamente compreendido em termos espaciais, e não temporais. Pretendemos mostrar de que maneira é possível pensar o movimento sem que isso resulte em paradoxos ou contradições referentes ao tempo tal como os expressos por Zenão. A partir da análise dessa ilusão, torna-se possível então compreender a realidade do movimento. Também lançaremos mão da análise do conceito de simultaneidade presente em Duração e simultaneidade, visando compreender como essa ilusão está fundada em uma incompreensão do conceito de movimento. Já em Matéria e memória, o problema se apresenta sob a ilusão de uma

\footnotetext{
${ }^{5}$ Segundo Morato, "as ilusões são o resultado inevitável da extrapolação das démarches práticas, configuradas pelo uso da linguagem e do entendimento, aos problemas especulativos, às questões de índole metafísica que os seres humanos se colocam no seu percurso histórico" (MORATO, 2007, p. 27). É por meio então de um trabalho de desconstruir e desmistificar certas ilusões que podemos voltar às coisas simples que envolvem a verdadeira natureza do tempo: o tempo como duração, e não como espaço, o conhecimento como intuição, e não como inteligência apenas.

${ }^{6} \mathrm{O}$ conceito de simultaneidade é criticado por Bergson, pois implica na noção de que dois acontecimentos possam acontecer no mesmo instante. A noção de instante implica um ponto matemático preciso em um tempo que "escorre", o que contradiz a ideia de tempo como duração. Para a teoria da relatividade, a simultaneidade é sempre entre dois instantes, embora no bergsonismo a noção de instante seja problemática. Sendo assim, ao compreender o tempo como duração no Ensaio sobre os dados imediatos da consciência, Bergson propõe uma crítica à noção de simultaneidade pois a duração não é composta por instantes.
} 
localização física da memória. Por meio de uma apresentação de duas formas da memória (a memória-hábito e a memória-lembrança), Bergson elimina a hipótese de que haveria uma localização física da lembrança no corpo, demonstrando então a existência de um passado puro.

A evolução criadora trata essencialmente da evolução da vida e de como o processo vital tornou-se possível apesar dos obstáculos impostos pela matéria. Para compreender como isso acontece, Bergson sugere uma crítica ao conceito de causalidade mecânica como princípio de explicação do real. No sentido de que uma causa A gera um efeito B, temos o efeito B já estava previamente contido em sua causa A, e, portanto, B já tinha algum grau de determinação. Sendo assim, se a natureza obedece a leis causais, não haveria explicação possível para o imprevisível e para a emergência do novo (como por exemplo, novos comportamentos, novas linhas evolutivas, novas espécies). Tentaremos mostrar como a crítica à causalidade mecânica e, consequentemente, às teorias mecanicistas, concebe a causalidade como apenas uma ilusão na qual acreditamos, e é pela superação dessa crença que é possível então compreender o que é o porvir no contexto da duração. Para tanto, Bergson usa o exemplo do vivente para demonstrar a evidência de que há imprevisibilidade e novidade do mundo, dando lugar ao que em nossa hipótese chamaremos de uma causalidade dinâmica que permite a emergência do novo.

Uma vez com essas ilusões situadas e examinadas, é possível então acessar o real tal como ele é, percebendo as suas verdadeiras "articulações", . Para que esse tipo de conhecimento seja possível e verdadeiro, é preciso um esforço de identificação das diferenças de natureza (isto é, as diferenças qualitativas, e não quantitativas) presentes na realidade. Bergson convida seus leitores a participarem nesse esforço:

\footnotetext{
${ }^{7}$ Bergson emprega o termo "articulações" do real quando se refere aos desdobramentos naturais da realidade. Normalmente, quando nos deparamos com um falso problema, é justamente porque falhamos em identificar essas articulações naturais, formatando o real em sistemas artificiais. $\mathrm{O}$ trabalho da filosofia seria o de perceber essas articulações naturais. Um exemplo do uso desse termo pode ser encontrado na coletânea de ensaios $O$ pensamento e o movente: "Mais, si l'on commence par écarter les concepts déjà faits, si l'on se donne une vision directe du réel, si l'on subdivise alors cette réalité en tenant compte de ses articulations, les concepts nouveaux qu'on devra bien former pour s'exprimer seront cette fois taillés à l'exacte mesure de l'objet: l'imprécision ne pourra naître que de leur extension à d'autres objets qu'ils embrasseraient également dans leur généralité, mais qui devront être étudiés en eux-mêmes, en dehors de ces concepts, quand on voudra les connaître à leur tour. » (BERGSON, 2013b, p. 23)
} 
Irei pedir-lhes que façam um esforço violento para afastar alguns dos esquemas artificiais que interpomos, sem o sabermos, entre a realidade e nós mesmos. Trata-se de romper com certos hábitos de pensar e de perceber que se tornaram naturais. Cabe voltar à percepção direta da mudança e da mobilidade. Eis um primeiro resultado desse esforço. Representar-nos-emos toda mudança, todo movimento, como absolutamente indivisivel ${ }^{8}$ (BERGSON, 2013b, p. 158, tradução nossa).

Quando nos representamos a mudança como "absolutamente indivisível”, isso significa representa-la com base em uma concepção do tempo como duração, e não em um tempo espacializado. O conceito de duração é utilizado em diversos momentos diferentes da obra de Bergson, fazendo com que o seu significado se torne cada vez mais amplo. No Ensaio sobre os dados imediatos da consciencia, a duração é o tempo da consciência distinto dos moldes impostos pelo espaço. É o tempo que pertence unicamente à consciência do sujeito, isto é, por meio de um conhecimento imediato que ocorre no presente. Em Matéria e memória, Bergson estende o conceito de duração a um passado puro, que tem relação com o presente na medida em que avança continuamente sobre ele. A consciência é então redefinida como uma penetração do passado se inserindo e criando um futuro naquilo que Bergson chama de memória. Consciência e memória, nesta obra, tornam-se sinônimas, que apresenta ainda a noção de passado puro. Em $A$ evolução criadora, a duração passa de uma característica da consciência ou da memória do sujeito para ser considerada como o tempo, por excelência, do universo, a partir da formulação de que "o universo dura" (l'univers dure). Nesse momento, torna-se importante pensar em que medida uma duração individual tem relação com o meio em que se encontra, o Universo, o Todo, que também dura. É a partir desse esforço que tentaremos compreender a dificuldade de acessar o real a partir das ilusões já mencionadas.

Nossa hipótese interpretativa é a de que essas três ilusões simultaneidade, localização física da lembrança e causalidade - refletem três momentos constitutivos da duração. No primeiro, a duração é característica exclusiva da consciência e de seus dados imediatos, isto é, do momento presente. No segundo, a duração é pensada em função da memória, ou seja, na dimensão do

\footnotetext{
${ }^{8}$ Je vais vous demander de faire un effort violent pour écarter quelques-uns des schémas artificiels que nous interposons à notre insu, entre la réalité et nous. Il s'agit de rompre avec certaines habitudes de penser et de percevoir qui nous sont devenues naturelles. Il faut revenir à la perception directe du changement et de la mobilité. Voici un premier résultat de cet effort. Nous nous représenterons tout changement, tout mouvement, comme absolument indivisibles.
} 
passado puro. No terceiro, em função do por vir que, para Bergson, se define a partir da criação do novo e da imprevisibilidade.

Cada uma dessas ilusões diz respeito a uma perspectiva da duração, que, por sua vez, só pode ser compreendida uma vez que essas três dimensões temporais são analisadas fora dos moldes do espaço. É na compreensão de uma totalidade do tempo que se forma, entre cada dimensão, um único elo - a duração-, a qual permite a compreensão do tempo puro. O que há de comum a essas três críticas é o fato de que, para compreender o tempo, devemos abrir mão da ideia de que modelos espaciais podem ser análogos a modelos temporais: só assim será possível compreender como uma teoria do conhecimento é possível tendo como fundamento um real concebido como mudança contínua.

\section{2}

\section{Contextualização}

\subsection{1}

\section{A crítica a uma concepção espacializada do tempo}

Bergson considerava que a principal contribuição de seu pensamento consistia na proposta de uma maneira original de pensar o tempo. Essa contribuição tem origem na hipótese de que o tempo deve ser concebido independentemente do espaço. Em outras palavras, quando pensamos o tempo como mensurável e divisível, pensamos em um tempo que existe em função do espaço, por exemplo, o tempo que decorre ao percorrermos uma distância entre dois pontos. $\mathrm{O}$ espaço puro é aquele que possibilita a nossa ação no mundo. Por outro lado, a consciência é capaz de certa experiência do tempo distinta de qualquer parâmetro espacial.

Em $O$ Bergsonismo, Gilles Deleuze sugere que toda a obra de Bergson é um processo de separação de mistos, isto é, o processo de perceber as verdadeiras diferenças de natureza, e não apenas as de grau, entre itens da realidade. Isso ocorre, por exemplo, quando comparamos sensações: se dizemos que sentimos mais ou menos dor de acordo com um estímulo doloroso, isso não significa que a 
dor menor poderia caber numericamente na dor maior. Por não se tratar de um fenômeno puramente espacial, a sensação de uma dor menor não poderia ser quantitativamente diferente do que a de uma dor maior, visto que essa diferença, para Bergson, não pode ser numérica. Isso significa que entre uma dor que a linguagem nos obriga caracterizar como "maior" e outra como "menor" não há uma diferença de grau, mas uma diferença de natureza. Esse mesmo processo de separação é necessário para que compreendamos o tempo verdadeiro: a duração. Esta se define como o tempo que é independente e inconfundível com o espaço: "trata-se, desta vez, de mistos mal analisados, nos quais são arbitrariamente agrupadas coisas que diferem por natureza." (DELEUZE, 1999, p. 11). A confusão que fazemos entre tempo e espaço é o exemplo fundamental de um falso problema:

(...) damo-nos do tempo uma representação penetrada de espaço. O deplorável é que não sabemos distinguir em tal representação os dois elementos componentes que diferem por natureza, as duas puras presenças da duração e da extensão. Misturamos tão bem a extensão e a duração que só podemos opor sua mistura a um princípio que se supõe ao mesmo tempo não espacial e não temporal, em relação ao qual espaço e tempo, extensão e duração vêm a ser tão-somente degradações (DELEUZE, 1999, p. 14).

É a partir da crítica a essa concepção mista do tempo que Bergson introduz o conceito de duração. Para tanto, é preciso compreender que as parcelas de tempo associadas ao espaço designam um "tempo descontínuo", caracterizado pela sucessão de instantâneos estáticos. A duração (o tempo puro, independente do espaço) é, na primeira obra de Bergson, o tempo característico da consciência. Há uma diferença de natureza, e não de grau, entre o que é extensivo (o espaço) e o que é intensivo (a duração): enquanto o espaço é homogêneo e mensurável, por um lado, a duração é, em contrapartida, pura heterogeneidade, mudança qualitativa contínua e intensiva. A duração é o tempo dos nossos estados de consciência e o cerne de toda mudança qualitativa, enquanto o espaço é o local da mudança quantitativa do mundo material.

Qual seria a relação possível entre essa crítica a uma concepção espacializada do tempo e o nosso conhecimento do real, uma vez que um dualismo entre estados internos e mundo material está no cerne de uma concepção do tempo como duração? Podemos desenvolver essa questão de duas maneiras: 
i. Pensando o termo "duração" como algo cujo escopo se amplia ao longo das obras analisadas. A duração, no Ensaio, diz respeito ao tempo da consciência ou, como afirma o próprio título deste trabalho, aos nossos dados imediatos. Em Matéria e memória, a compreensão de um passado que dura e, consequentemente, é independente do presente, é o pressuposto para que se estabeleça uma teoria da percepção baseada no tempo, e não no espaço. A afirmação de que "o universo dura", presente nas paginas iniciais de $A$ evolução criadora, nos mostra, enfim, que a duração se estende a todo o universo. Sendo assim, compreendendo um caráter de certa forma crescente do conceito de duração, é possível superar o dualismo aparentemente decisivo do Ensaio. O conceito de duração tem sua gênese na consciência, mas passa por um processo de abertura para o passado e o porvir. Isso se deve ao fato de que a consciência é definida como o presente, embora ela tenha acesso à memória (o passado) e possa arquitetar ações a serem executadas no porvir.

ii. Sob o ângulo de uma teoria do conhecimento, a questão da percepção da mudança é primordial. Conforme enunciado em A percepção da mudança, conferência pronunciada em Oxford em 1911, o conhecimento depende da nossa percepção, e conceitos (isto é, termos que definem o real tornando-o acessível a outras consciências e individualidades) são criados justamente na medida em que completamos os aspectos finitos e as limitações da percepção. A percepção não é completa ou total, mas ainda assim é possível criar conceitos que deem conta daquilo que é percebido, completando as lacunas ou limitações da percepção. Os conceitos existem, então, para que nosso entendimento seja capaz de suprir as limitações da percepção, pois justamente por termos uma concepção espacializada do tempo, buscamos captar o imóvel, o estático. O que Bergson sugere é a construção de conceitos-móveis, ou seja, moldáveis a uma realidade cuja essência é justamente a mudança. 


\subsection{2 \\ 0 "conceito" de duração}

São diversas as definições de duração na obra de Bergson. Na primeira delas, lemos que "a duração pura é a forma que toma a sucessão de nossos estados de consciência quando o nosso eu se deixa viver, quando ele se abstém de estabelecer uma separação entre o estado presente e os estados anteriores"9 (BERGSON, 2013, p. 75, tradução nossa). Essa definição, presente no Ensaio sobre os dados imediatos da consciência, se desenvolve no decorrer de toda a obra de Bergson, de modo que a duração parte da consciência, se estende para o campo da memória e, em seguida, para todo o universo, quando o autor afirma que todo o universo dura, nas páginas iniciais de $A$ evolução criadora. Essa ampliação do conceito de duração deve ser notada ao longo da análise dos problemas abordados em cada obra.

O problema do conhecimento do real parte de uma concepção estática do tempo da consciência como análogo a um tempo numérico, isto é, um tempo sucessivo, divisível em infinitas partes (uma concepção espacializada do tempo). Sendo assim, é compreendendo a duração como o tempo real, livre de uma contaminação do espaço, que é possível então partir para o conhecimento da realidade do passado e, a seguir, da realidade do mundo.

O uso da determinação de um "conceito" pode parecer contraditória no que diz respeito à duração, visto que se trata exatamente da mudança qualitativa e de uma certa fluidez, que se opõe à suposta rigidez e estabilidade de um conceito $^{10}$ entendido no sentido usual. No entanto, é importante ressaltar que a colocação da possibilidade de um conceito fluído caracteriza a busca do método bergsoniano. O método desta filosofia, na medida em que toma para si a tarefa de

\footnotetext{
${ }^{9}$ « La durée toute pure est la forme que prend la succession de nos états de conscience quand notre moi se laisse vivre, quand il s'abstient d'établir une séparation entre l'état présent et les états antérieurs» (BERGSON, 2013, p. 75).

${ }^{10}$ Aux concepts que fournit l'intelligence elle substitue simplement un concept unique qui les résume tous et qui est, par conséquent toujours le même, de quelque nom qu'on l'appelle : la Substance, le Moi, l'Idée, la Volonté. La philosophie ainsi entendue, nécessairement panthéistique, n'aura pas de peine à expliquer déductivement toutes choses, puisqu'elle sera donnée par avance, dans un principe qui est le concept des concepts, tout le réel et tout le possible. Mais cette explication sera vague et hypothétique, cette unité sera artificielle, et cette philosophie s'appliquerait aussi bien à un monde tout différent du nôtre. (BERGSON, 2013b, p. 19 checar no livro).
} 
conhecer o real, é o de pensar em duração (penser en durée). É na medida em que compreendemos a verdadeira natureza do tempo que acessamos as "verdadeiras articulações do real". Em nossa perspectiva, uma filosofia da duração não significa uma ausência de conceitos, embora a própria noção de um conceito deva ser reavaliada à luz do método de conhecimento da intuição em oposição ao da inteligência ${ }^{11}$ que opera recortes artificiais no mundo, criando sistemas fechados que não ocorrem naturalmente dessa maneira.

${ }^{11}$ A inteligência é a faculdade que nos permite pensar por meio de análise, e se opõe a um conhecimento imediato e intuitivo sendo um conhecimento mediado pelo espaço. Essa crítica encontra-se principalmente em $A$ evolução criadora e será apresentada em mais detalhes no terceiro capítulo desse texto. 


\section{2 \\ O presente e a ilusão da simultaneidade}

\section{1}

\section{Uma metafísica do movente}

Bergson inaugura as páginas do Ensaio sobre os dados imediatos da consciência propondo uma diferença fundamental entre um tempo heterogêneo e um espaço homogêneo. Esta distinção entra em jogo no momento em que o filósofo busca redefinir o que é o movimento e, consequentemente, a nossa percepção da mudança. A relação entre esses termos é a de que, para apreendermos a mudança nela mesma (isto é, em função do tempo, e não do espaço), é preciso retraçar uma diferença fundamental entre o tempo heterogêneo e o espaço homogêneo. A mudança é o que há de temporal no movimento, enquanto o movimento em si é apenas deslocamento espacial. Quando confundimos movimento e mudança, como no exemplo do paradoxo de Aquiles e da tartaruga, tendemos a ter uma concepção errônea de mudança, em que tempo e movimento coincidem e podem ser divisíveis infinitamente. Tentaremos, a partir da ilusão da simultaneidade, demonstrar qual o problema de uma falsa concepção de movimento e, em seguida, como pode ocorrer a percepção da mudança. Mostraremos em uma primeira etapa como, a partir de um conhecimento vindo da percepção, podemos ter um conhecimento de fato da mudança, e não apenas de direito.

A nossa hipótese é a de que, para resolver esses problemas, é preciso partir do pressuposto de que o Ensaio tome como ponto de início uma metafísica do movente, ou seja, daquilo cuja característica fundamental é a mudança. Tratase de uma tentativa constante de se recuperar uma metafísica que foi supostamente fundada em bases inadequadas. Nossa hipótese interpretativa parte do pressuposto de que o projeto filosófico bergsoniano tem como meta refundar uma metafísica baseada em uma concepção do tempo como duração, isto em contraposição à metafísica clássica que formula seus problemas com base em uma concepção mista de espaço e tempo. A investigação bersgoniana diz respeito a um movente absoluto, à mudança contínua, mas que não exclua a possibilidade de um 
conhecimento sobre esse movente: e esse conhecimento é metafísico. Refundar a metafísica em função do tempo é o mesmo que refundá-la em função do real, que é movente. Nesse sentido, ao analisarmos o presente, o passado e o futuro como âmbitos de um tempo único - a duração -, sugerimos direcionar nossa pesquisa com base nos métodos dessa suposta metafísica do movente. Esse método procede por meio da compreensão das ilusões do senso comum, que nos proporciona uma experiência mista do tempo com o espaço, assim como a identificação de falsos problemas e das diferenças de natureza, e não de grau, entre tempo e espaço. Sendo assim, propomos uma metafísica do movente como o método para se acessar o real enquanto mudança contínua.

Segundo Bergson, os paradoxos de Zenão relativos ao movimento e à mudança estão na origem da metafísica:

A metafísica nasceu, com efeito, dos argumentos de Zenão de Eléia relativos à mudança e ao movimento. É Zenão quem, ao atirar atenção sobre as absurdidades do que ele chamava de movimento e de mudança, levou os filósofos - Platão em primeiro - a buscar a realidade coerente e verdadeira daquilo que não muda ${ }^{12}$ (BERGSON, 2013b, p. 156, tradução nossa).

É importante ressaltar que, embora faça uma crítica à metafísica, Bergson ainda pretende aplicar o termo à sua filosofia. Portanto, não se trata de um projeto filosófico que deseja superar a metafísica ou propor uma teoria independente dela, mas sim encontrar um método para que seja possível uma metafísica do movente, e não do estático e do imutável. O movimento, a mudança, ou seja, o tempo sendo pensado em função daquilo que é mutável, imprevisível, se colocam então como alvo desta metafísica, e não daquilo que é permanente.

Este procedimento aponta para o momento histórico em que surge o bergsonismo na filosofia. Até aquele momento, a metafísica desde o platonismo foi associada à verdade da realidade daquilo que não muda, das formas eternas e imutáveis. A principal reversão do bergsonismo é, então, a de propor um estudo da mudança tendo em vista que a verdadeira essência do real não é a sua permanência ou imutabilidade, mas sim a sua mudança contínua. A verdade sobre o real deve levar isso em conta como principal característica, sem abrir mão de

\footnotetext{
${ }^{12}$ La métaphysique est née, en effet, des arguments de Zénon d’Élée relatifs au changement et au mouvement. C'est Zénon qui, en attirant l'attention sur l'absurdité de ce qu'il appelait mouvement et changement, amena les philosophes - Platon tout le premier - à chercher la réalité cohérente et vraie dans ce qui ne change pas.
} 
uma metafísica, ou seja, utilizando métodos metafísicos, como por exemplo o estudo do tempo heterogêneo (tempo puro) em sua dimensão própria, e não na do espaço. De certa forma, o platonismo não foi capaz de pensar o movente porque não alcança o tempo em si, mas apenas o espaço. Trata-se, então, de reestabelecer o lugar próprio do tempo no pensamento metafísico, mas, para que isso seja possível, é preciso pensar na perspectiva do tempo, e não na do espaço.

Bergson toma os paradoxos de Zenão como o início de sua análise da diferença de natureza existente entre um tempo puro (a duração) e o espaço, entre movimento e simultaneidade ${ }^{13}$. Em um ensaio de 1903 publicado na Revue de Métaphysique et de morale e intitulado Introduction à la métaphysique, Bergson propõe a distinção entre um conhecimento intuitivo e um conhecimento analítico. A intuição é aquilo que nos permite ter acesso à própria coisa, se opondo à análise:

Chamamos aqui de intuição a simpatia pela qual nos transportamos para o interior de um objeto para coincidir com o que ele tem de único e, consequentemente, de inexprimível. Ao contrário, a análise é a operação que traz o objeto de volta aos seus elementos já conhecidos, isto é, comuns a esse objeto e a outros. Analisar consiste então em expressar uma coisa em função do que ela não é ${ }^{14}$ (BERGSON, 2013b, p. 181, tradução nossa).

O conhecimento construído por análise, portanto, permite que um objeto seja atribuído a um conceito pré-existente ao objeto. Sendo assim, ele não se molda exatamente ao objeto pois é um conhecimento mediato. Já a intuição é o ato simples que nos permite acessar a coisa imediatamente, tal como ela é. Essa definição, porém, parece incompleta na medida em que a coisa, sendo real, deve ser também mudança contínua. O que seria, então, uma intuição da mudança e como se daria o conhecimento da coisa enquanto mudança contínua? A abordagem desse problema depende da relação entre mudança e movimento e do motivo pelo qual uma análise do movimento é falsa em relação a uma intuição do movimento.

${ }^{13}$ Empregaremos o termo simultaneidade, em um primeiro momento, conforme é utilizado na física, isto é, como a possibilidade de dois acontecimentos no espaço ocorrerem no mesmo instante. Posteriormente, a crítica à noção de instante implica na impossibilidade de uma simultaneidade de fato.

${ }^{14}$ Nous appelons ici intuition la sympathie par laquelle on se transporte à l'intérieur d'un objet pour coïncider avec ce qu'il a d'unique et par conséquent d'inexprimable. Au contraire, l'analyse est l'opération qui ramène l'objet à des éléments déjà connus, c'est-àdire en fonction de ce qui n'est pas elle. 
$\mathrm{Na}$ perspectiva da história da filosofia, a metafísica surge com a clássica questão "porque há o Ser e não o nada". O que torna a proposta de Bergson um tanto quanto ambiciosa é a tentativa de compreender por que essa pergunta é um falso problema. Em sua visão, a pergunta já é mal colocada de início, pois ela parte do pressuposto de que entre o Tudo e o Nada exista uma diferença de natureza, quando há apenas, na realidade, uma diferença de grau. Isso pode ser exemplificado pelo problema do par ordem/desordem. Segundo o autor, tendemos a pensar a desordem como "ausência de ordem". Na realidade, o que ocorre é que na ideia de desordem há mais, e não menos do que na ideia de ordem, pois a ideia de desordem implica no conhecimento do que é a ordem mais o conhecimento de sua ausência, isto é a não-ordem.

Então, ao querer suprimir a ordem, vocês se deparam com duas ou mais. O que volta a dizer que a concepção de uma ordem vindo se sobrepor a uma "ausência de ordem" implica em um absurdo, e que o problema se esvai. As duas ilusões que acabo de assinalar formam apenas uma. Elas consistem em acreditar que há menos na ideia do vazio do que na ideia do cheio, menos no conceito de ordem do que no conceito de desordem ${ }^{15}$. (BERGSON, 2013b, p. 109, tradução nossa).

O problema do fundamento da metafísica se exemplifica por meio do par ordem-desordem na medida em que, para Bergson, postular "ou a ordem ou a desordem" com diferenças de grau é um falso pressuposto para se iniciar um pensamento filosófico metafísico. Em contrapartida, sua proposta é a de propor o que chamaremos de uma "metafísica do movente" isto é, compreender o movente no plano metafísico, em primeiro lugar, a partir da distinção fundamental entre tempo heterogêneo e espaço homogêneo, para, em seguida, introduzir o movimento nesse sistema. A metafísica é o que nos permite compreender e apreender o real e conhecê-lo enquanto tal, pois é justamente a disciplina filosófica que nos permite trabalhar a partir da intuição - um ato simples - em oposição à análise. A inteligência, a faculdade da razão, por meio da qual sempre se tentou encontrar uma explicação para as questões metafísicas, não é a faculdade por excelência que pode resolver tais questões. Para Bergson, a

\footnotetext{
${ }^{15}$ Donc, à vouloir supprimer l'ordre, vous vous en donnez deux ou plusieurs. Ce qui revient à dire que la conception d'un ordre venant se surajouter à une " absence d'ordre » implique une absurdité, et que le problème s'évanouit. Les deux illusions que je viens de signaler n'en font réellement qu'une. Elles consistent à croire qu'il y a moins dans l'idée du vide que dans celle du plein, moins dans le concept de désordre que dans celui d'ordre.
} 
metafísica é a "experiência integral" ${ }^{16}$ (BERGSON, 2013b, p. 227, tradução nossa), e, portanto, não pode ser inteiramente compreendida pela inteligência, pois esta é a faculdade que opera no espaço e não no tempo. A metafísica é aquilo que compreende a realidade como movente, e isso só é possível na medida em que nos desfizermos de um pensamento nos moldes do espaço para encontrar o tempo puro, isto é, a experiência da duração. O pensamento da duração, que Bergson chama de "pensar em duração" (penser en durée) seria o meio de conhecimento em uma metafísica do movente.

Não se trata de uma metafísica do estático, mas sim daquilo cuja essência é mudar, durar. Para explicar essa metafísica do movente, analisaremos a insuficiência de um conhecimento por análise para o conhecimento do real à luz de duas distinções: a diferença entre um tempo heterogêneo e um espaço homogêneo e a distinção entre mudança e movimento na medida em que é preciso se desfazer de uma ilusão da simultaneidade. Em seguida, retomaremos a nossa hipótese inicial em uma demonstração partindo de uma intuição do movimento (em contraposição a um conhecimento analítico) será possível, então, compreender a realidade do presente.

\subsection{1}

\section{Tempo heterogêneo x espaço homogêneo}

A investigação acerca da duração surge da necessidade de se fazer uma distinção real, e não apenas abstrata, entre tempo e espaço. Mais especificamente, trata-se de introduzir uma diferença entre o que é numérico, quantificável, e aquilo que é intensivo, qualitativo. É nessa distinção fundamental que é possível reestabelecer as "articulações do real", culminando em um conhecimento intuitivo que é, por se fundar em um respeito à mobilidade, verdadeiro. Esta conversão exige um esforço imenso, ou, segundo a interpretação de Deleuze, um método ${ }^{17}$

\footnotetext{
${ }^{16}$ En ce sens, la métaphysique n'a rien de commun avec une généralisation de l'expérience, et néanmoins, elle pourrait se définir comme l'expérience intégrale.

${ }^{17}$ Em O bergsonismo (1999) Deleuze introduz a ideia de uma "intuição como método", com cinco etapas definidas. Nesse momento, utilizaremos apenas a primeira e a segunda etapa que consistem em: "Aplicar a prova do verdadeiro e do falso aos próprios problemas, denunciar os falsos problemas, reconciliar verdade e criação no nível dos problemas" (DELEUZE, 1999, p. 8) e "Lutar
} 
que estabelece a necessidade de se pensar para além de falsos problemas e de problemas inexistentes. Um dos tipos de falsos problemas é o de identificar diferenças de natureza (isto é, diferenças qualitativas) onde há apenas diferenças de grau (quantitativas). Deleuze chama a estes de problemas mal colocados: "os problemas mal colocados, o segundo tipo ${ }^{18}$ de falsos problemas, fazem intervir, parece, um mecanismo diferente, nos quais são arbitrariamente agrupadas as coisas que diferem por natureza"19 (DELEUZE, 1999, p. 11).

Os problemas mal colocados nos induzem ao erro na medida em que separamos o real de acordo com articulações artificiais, e não de acordo com suas articulações naturais. As articulações artificiais são aquelas que presumimos por meio de análise, completando, por meio do entendimento, as lacunas da percepção, o que gera um conhecimento mediato: primeiro percebemos para depois formamos um conceito geral. As articulações naturais são aquelas que conhecemos por intuição, ou seja, imediatamente, e refletem da maneira mais exata possível o real e seu caráter de mudança contínua. Elas consistem em uma coincidência exata entre objeto e conceito. Quando destacamos artificialmente itens que diferem por natureza e falhamos em identificar essa diferença, nos encontramos diante de mistos mal analisados, como por exemplo, no caso da diferença de natureza existente entre extensão e duração, ou seja, entre espaço e tempo:

Bergson não ignora que as coisas, de fato, realmente se misturam; a própria experiência só nos propicia mistos. Por exemplo - damo-nos do tempo uma representação penetrada de espaço. O deplorável é que não sabemos distinguir em tal representação os dois elementos componentes que diferem por natureza, as duas puras presenças da duração e da extensão. Misturamos tão bem a extensão e a duração que só podemos opor sua mistura a um princípio que se supõe ao mesmo tempo não espacial e não temporal, em relação ao qual espaço e tempo, extensão e duração vêm a ser tão-somente degradações ${ }^{20}$ (DELEUZE, 1999, p. $14)$.

contra a ilusão, reencontrar as verdadeiras diferenças de natureza e as articulações do real" (DELEUZE, 1999, p. 14).

${ }^{18} \mathrm{O}$ primeiro tipo de falso problema diz respeito aos problemas entre ordem-desordem, cheiovazio, ser-nada.

${ }^{19}$ Les problèmes mal-posés, le second type de faux problèmes, semblent faire intervenir un mécanisme différent : il s'agit cette fois de mixtes mal analysés, dans lesquels on groupe arbitrairement des choses qui different en nature (DELEUZE, 2004, p. 7) .

${ }^{20}$ Bergson n'ignore pas que les choses se mélangent en réalité, en fait; l'expérience elle-même ne nous livre que des mixtes. Mais le mal n'est pas là. Par exemple, nous nous faisons du temps une représentation pénétrée d'espace. Ce qui est fâcheux, c'est que nous ne savons plus distinguer dans cette représentation, les deux éléments composants qui diffèrent en nature, les deux pures présences de la durée et de l'étendue. Nous mélangeons si bien l'étendue et la durée que nous ne 
Em que consiste então essa diferença de natureza? Como podemos passar de uma análise sobre a diferença entre tempo e espaço para uma intuição simples dessa diferença? Esse parece ser a primeira etapa fundamental de todo o Ensaio sobre os dados imediatos da consciência, e ela ocorre em dois momentos: o primeiro diz respeito a uma observação sobre o erro comum de se acreditar na possibilidade de mensurar sensações. Isso se relaciona a uma suposta analogia entre os estímulos externos, existentes no espaço, e seus correspondentes na sensação de um sujeito, que dependem de uma duração interna e individual. O segundo momento dependente desse primeiro, diz respeito à distinção entre tempo heterogêneo e espaço homogêneo.

Compreende-se por espaço homogêneo um espaço infinitamente divisível em partes iguais e as partes resultantes dessa divisão diferem entre si em grau, e não em natureza. $O$ homogêneo se caracteriza por uma ausência total de qualidade. O tempo heterogêneo não é divisível em partes, pois trata-se de um fluxo contínuo em que cada divisão hipotética resultaria em uma diferença de natureza - é a ausência de quantidade e a presença de qualidade apenas.

A crítica à ideia de que é possível mensurar matematicamente as sensações internas causadas por estímulos externos inaugura no Ensaio uma crítica direta à psicofísica de Willhelm Wundt (1832-1920) e de Gustav Theodor Fechner (18011887), principalmente este último, fundador da disciplina em questão. Sua principal tese era a de que seria possível medir, a partir de uma relação de proporcionalidade expressa por uma fórmula, a relação entre uma variação do estímulo e a intensidade de uma sensação. Em Elements of psychophysics (FECHNER, 1966), Fechner formula o objetivo da psicofísica como sendo o seguinte:

O ponto de vista a partir do qual pretendemos atacar a nossa tarefa é o seguinte: antes mesmo de que os meios para descobrir a natureza de processos do corpo que se encontram em relação direta às nossas atividades mentais estejam disponíveis, tentaremos, não obstante, sermos capazes de determinar em alguma medida quantitativa a relação entre eles. A sensação depende do estímulo; uma sensação mais forte depende de um estímulo mais forte (...) Até o ponto em que relações regidas por leis entre sensação e estímulo podem ser encontradas, estas

pouvons plus opposer leur mélange qu'à un principe supposé à la fois non spatial et temporel, par rapport auquel espace et temps, durée et étendue, ne sont plus que des dégradations (DELEUZE, 2004, p. 12). 
precisam incluir relações regidas por leis entre o estímulo e essa atividade física interna $(. . .)^{21}$ (FECHNER, 1966, p. 10, tradução nossa).

Bergson se interessa por essas questões psicofísicas para encontrar um fundamento psicológico para a sua crítica sobre a suposta analogia entre fenômenos espaciais e fenômenos temporais. A base de seu argumento é a de que não é possível estabelecer uma analogia direta (por meio de uma relação matemática e numérica) entre estímulos físicos (luz, calor, pressão, etc.) e as respectivas sensações internas causadas por tais estímulos. No entanto, a ideia de que isso é possível se manifesta no próprio senso comum:

O senso comum se pronuncia, aliás sem a menor hesitação sobre esse ponto; dizemos que sentimos mais ou menos calor, que estamos mais ou menos tristes, e essa distinção de mais em menos, mesmo quando a prolongamos na região dos fatos subjetivos e das coisas inextensas, não surpreende ninguém. Há aí um problema muito obscuro, e um problema muito mais grave do que o imaginamos geralmente $^{22}$ (BERGSON, p. 1, 2013a, tradução nossa).

Bergson propõe então uma comparação com a ideia de número. Um número maior do que o outro pode conter um número menor, e um número menor pode ser contido em um número maior. Por exemplo, o número dois é menor do que o número seis, pois o número seis pode conter até três vezes o número dois. Quando então nos expressamos em termos quantitativos (mais ou menos) ao falar sobre sensações (mais ou menos calor, mais ou menos tristeza), nos expressamos numericamente sobre fatos que dizem respeito a intensidades e não a grandezas, o que é questionado da seguinte maneira: "mas como uma sensação mais intensa poderia conter uma sensação de intensidade menor?"23 (BERGSON, p. 2, 2013a, tradução nossa). Kant encontrara uma solução a esse problema por meio da ideia de uma "grandeza intensiva", apresentada na Crítica da Razão Pura. "Ora, chamo

\footnotetext{
21 "The point of view from which we plan to attack our task is as follows: even before the means are available to discover the nature of processes of the body that stand in direct relation to our mental activities, we will nevertheless be able to determine to a certain degree the quantitative relationship between them. Sensation depends on stimulation; a stronger sensation depends on a stronger stimulus; the stimulus, however, causes sensation only via the intermediate action of some internal process of the body. To the extent that lawful relationships between sensation and stimulus can be found, they must include lawful relationships between the stimulus and this inner physical activity, which obey the same general laws of interaction of bodily processes and thereby gives us a basis for drawing general conclusions about the nature of this inner activity."

${ }^{22}$ Le sens commun se prononce d'ailleurs sans la moindre hésitation sur ce point ; on dit qu'on a plus ou moins chaud, qu'on est plus ou moins triste, et cette distinction de plus en moins, même quand on la prolonge dans la région des faits subjectifs et des choses inétendues, ne surprend personne. Il y a là un problème fort obscur, et un problème beaucoup plus grave qu'on ne se l'imagine généralement.

${ }^{23}$ Mais comment une sensation plus intense contiendra-t-elle une sensation de moindre intensité ?
} 
de grandeza intensiva à grandeza que é apreendida apenas como unidade e na qual a pluralidade não pode ser representada senão pela sua aproximação à negação $=0$. Toda realidade no fenômeno tem então uma grandeza intensiva, isto é, um grau” (KANT, p. 169, 1968, tradução nossa) ${ }^{24}$. Trata-se, na hipótese kantiana, de atribuir a um fenômeno não apenas uma grandeza extensiva (numérica), mas também a noção de uma intensidade mensurável por meio de uma variação em relação a um grau zero hipotético (equivalente à ausência de sensações).

Bergson irá dirigir uma crítica direta a essa ideia: esse grau zero, sendo hipotético e apenas teórico, não pode ser a base da mensuração de uma intensidade. Pensar que é possível medir intensidades é apenas uma confusão, uma ilusão do senso comum, já que só a quantidade apenas pode ser mensurada. Essa confusão vem justamente do fato de concebermos tempo e espaço como apenas diferindo em grau, e não em natureza. Isto é, quando pensamos o tempo, pensamos em uma instância numericamente divisível em instantes que se sucedem, e, assim sendo, confundimos o extenso com o inextenso em uma só instância: o tempo impregnado de espaço. Para nos desfazermos dessa ilusão, é preciso conceber uma diferença de natureza, e não mais de grau, entre tempo e espaço. Isso se relaciona com as sensações, pois quando nos referimos à dor ou ao prazer, o nosso senso comum se expressa como se realmente houvesse essa analogia entre espaço e tempo, ou seja, como se houvesse uma diferença de grau e não de natureza.

Essa diferença de natureza pode ser explicada pela distinção entre espaço homogêneo e tempo heterogêneo. É essa distinção que permite também formalizar a crítica feita ao objetivo geral da psicofísica: quando recebemos algum estímulo tal como calor ou frio, esse estímulo pode ser quantificado por determinada temperatura. Quando recebemos esse estímulo, nossa inteligência nos diz que, em comparação a outro estímulo recebido, esse primeiro é mais ou menos quente, mais ou menos frio, nos baseando na quantificação possível do estímulo exterior recebido. Se esse fosse realmente o caso, seria então possível quantificar as sensações internas, o que é justamente o contrário da hipótese do Ensaio.

\footnotetext{
${ }^{24}$ Or, j'appelle grandeur intensive la grandeur qui n'est appréhendée que comme unité et dans laquelle la pluralité ne peut être représentée que par son rapprochement de la négation $=0$. Toute réalité dans le phénomène a donc une grandeur intensive, c'est-à-dire un degré.
} 
Analisando a questão em detalhes, podemos inferir que na realidade não é possível traçar uma analogia entre os estímulos externos, quantificáveis, e as sensações. Nossa linguagem se expressa em termos de mais ou menos calor ou frio, quando na realidade isso ocorre justamente porque pensamos que há uma analogia entre o que é externo e os dados da consciência. Se isso fosse o caso, a noção kantiana de grandeza intensiva seria exata, na medida em que as sensações podem ser relativizadas e quantificáveis a partir de determinada escala numérica. Cairíamos então no argumento de que sensações podem ser quantificadas e, portanto, podem ser contidas umas nas outras. A solução para nos desfazermos dessa analogia é então a de compreender que a consciência pertence ao registro do tempo heterogêneo, enquanto esses estímulos encontram-se em um espaço homogêneo.

Bergson inaugura então dois registros para que seja possível pensar, por um lado, uma realidade quantitativa, e, por outro, uma realidade qualitativa. Desta maneira, afirmará que "o que é preciso dizer, é que conhecemos duas realidades de ordem diferente, uma heterogênea, a das qualidades sensíveis, outra homogênea, que é o espaço"25 (BERGSON, 2013a, p. 73, tradução nossa).

O espaço se define, então, pelo homogêneo e "o homogêneo consiste aqui em uma ausência de toda qualidade"26 (BERGSON, 2013a, p. 73, tradução nossa). Essa ausência de qualidade se refere à característica do espaço como puramente quantitativo (por exemplo, é divisível ao infinito, é composto por partes, em oposição à pura qualidade, característica da duração). Uma concepção espacializada do tempo significa justamente confundir o tempo com o homogêneo, isto é, como quantidade e não como qualidade. O que seria então o tempo não-homogêneo, isto é o tempo como heterogeneidade pura? É exatamente nesse momento de sua análise que Bergson introduz a noção de duração:

A duração pura é a forma que toma a sucessão de nossos estados de consciência quando o nosso eu se deixa viver, quando ele se abstém de estabelecer uma separação entre o estado presente e os estados anteriores ${ }^{27}$ (BERGSON, 2013a, p. 75 , tradução nossa).

\footnotetext{
${ }^{25} \mathrm{Ce}$ qu'il faut dire, c'est que nous connaissons deux réalités d'ordre différent, l'une hétérogène, celle des qualités sensibles, l'autre homogène, qui est l'espace.

${ }^{26}$ Car l'homogénéité consistant ici dans l'absence de toute qualité, on ne voit pas comment deux formes de l'homogène se distingueraient l'une de l'autre.

${ }^{27} \mathrm{La}$ durée toute pure est la forme que prend la succession de nos états de conscience quand notre moi se laisse vivre, quand il s'abstient d'établir une séparation entre l'état présent et les états antérieurs.
} 
Analisando essa primeira definição de duração, destacam-se alguns elementos essenciais. Em primeiro lugar, nota-se que a duração é o termo utilizado para explicar qual seria uma concepção de tempo independente do espaço ou de uma concepção espacializada do tempo (isto é, o tempo homogêneo) - a duração é então o tempo heterogêneo. Em seguida, nota-se também que a duração é, em oposição ao espaço, aquilo que é definido por meio dos estados da consciência, o que a restringe a um mundo interno, pessoal, individual. Cada indivíduo, com sua história pessoal, não pode ter durações idênticas, pois cada momento heterogêneo da duração se inscreve em uma história estritamente individual - vemos então mais um aspecto da heterogeneidade do tempo.

A duração é interna, o espaço é externo; a duração é característica dos dados da consciência e é, portanto, individual. É importante lembrar que esse aspecto individual da duração é central ao Ensaio, mas é estendido a outras direções no decorrer da obra de Bergson. Como afirmamos acima, em Matéria e memória, o filósofo estenderá o conceito de duração ao corpo, e, consequentemente, à realidade do passado. Em A evolução criadora, é o universo inteiro que dura em um movimento que visa compreender à criação contínua de novidade na perspectiva do porvir. Em um movimento único de crescimento, duração se assimila a consciência, memória e porvir, o que, em uma perspectiva clássica do tempo, significaria a sua totalidade constituída por presente, passado e futuro.

A distinção entre espaço homogêneo e tempo heterogêneo proposta no Ensaio foi muitas vezes criticada por ser uma solução dualista, visto que impõe uma separação aparentemente rígida entre aquilo que é externo, quantitativo, e a consciência, interna, qualitativa. Em nossa hipótese interpretativa, essa separação rígida aparece como uma explicação didática e formal para a existência de uma diferença de natureza entre tempo e espaço. Na prática, esse dualismo parece se resolver na consideração entre duas formas do eu - um eu de superfície e um eu profundo, é que esse dualismo parece se superar na medida em que há uma linha quase indefinível entre um eu prático, ou seja, um eu que precisa pensar em termos espaciais para poder agir no mundo, viver e sobreviver e um eu profundo, ou seja, o eu dos sentimentos como o sentimento estético, o amor, a tristeza, que passa pelas sensações simples até os estados mais profundos da consciência, que 
Bergson chama de "sentimentos profundos" (angústia, medo, amor, entre outros).

Em seu artigo intitulado Bergson e os dualismos, Morato afirma que:

Dessa forma, se o método de investigação do Ensaio é dualista ou opera instituindo dualidades, sua conclusão não o é categoricamente: ela resulta na afirmação da existência da duração, da multiplicidade qualitativa, da experiência psicológica e da liberdade (...) (MORATO, 2004, p. 85).

Trata-se então de um “dualismo metodológico", por meio do qual Bergson precisa lançar mão para explicar as diferenças de natureza entre uma multiplicidade qualitativa e uma multiplicidade quantitativa, o tempo heterogêneo e o espaço homogêneo. O Ensaio como ponto de partida de um pensamento da duração precisa apresentar uma metodologia dualista, de separação dos mistos, para que então seja possível introduzir aspectos da realidade tal como ela se apresenta à consciência, sempre como uma indissociabilidade entre tempo e espaço. Uma vez reinstauradas as verdadeiras diferenças de natureza entre os mistos mal-analisados, será possível então compreender os mecanismos de funcionamento desses elementos e, sempre com uma perspectiva crítica, propor uma superação dos aparentes dualismos entre tempo e espaço, espírito e matéria, coisa e representação.

\subsection{2 \\ Percepção da mudança e conhecimento da mudança}

Uma vez introduzida a diferença entre tempo real (heterogêneo), isto é duração - e espaço homogêneo, passaremos para a questão da percepção e do conhecimento da mudança para, a seguir, analisar o problema da simultaneidade e do movimento. Em um ensaio intitulado "A percepção da mudança" (presente na coletânea de 1932, O pensamento e o movente), Bergson apresenta o argumento de que, para que a mudança seja percebida, ela precisa ser concebida como indivisível. $\mathrm{O}$ argumento se desenvolve a partir do exemplo do movimento: se eu concebo um movimento de um ponto A para um ponto $\mathrm{B}$, ele é um único movimento que parte de A em direção a B. Caso seja possível dividi-lo em duas partes, trata-se então de dois movimentos, únicos e indivisíveis: o primeiro de $\mathrm{A}$ 
até um meio-termo $\mathrm{C}$, e o segundo de $\mathrm{C}$ em relação a $\mathrm{B}$. Essa divisão não é a divisão de um movimento em duas partes, mas sim uma divisão que resulta em dois novos movimentos. Isto acontece por haver uma confusão entre o movimento, que é indivisível, e o trajeto percorrido pelos pontos móveis, este sim infinitamente divisível. A relação entre percurso e movimento resume-se da seguinte maneira:

É sempre de um só impulso que um trajeto é percorrido, quando não há paradas no trajeto. O impulso pode durar alguns segundos, ou dias, meses, anos: pouco importa. A partir do momento que ele é único, ele é indecomponível. Uma vez o trajeto efetuado, como a trajetória é espaço e o espaço é indefinidamente divisível, nós nos figuramos que o movimento ele mesmo é divisível infinitamente $^{28}$ (BERGSON, 2013b, p. 159, tradução nossa).

Essa ideia de um movimento indivisível durante o percurso de um trajeto entre dois pontos é a primeira etapa de uma crítica à noção de movimento concebido no espaço divisível. A segunda etapa é justamente essa ideia aplicada a uma análise dos paradoxos de Zenão. É a partir desses dois momentos que podemos investigar o que seria a ilusão da simultaneidade, ou seja, a ilusão de que dois eventos podem acontecer ao mesmo tempo, em localizações diferentes do espaço. É na compreensão de como ultrapassar essa ilusão que torna-se possível o conhecimento da realidade do presente.

Bergson enuncia como tarefa do ensaio $A$ percepção da mudança a necessidade de se restabelecer uma continuidade aparentemente perdida no conhecimento. $\mathrm{O}$ conhecimento a partir da inteligência tende a compreender o todo por meio de uma separação arbitrária de suas partes, para então poder efetuar uma análise, gerando uma descontinuidade artificial das partes com relação ao todo. O conhecimento da mudança deve se dar de forma contínua, em oposição a essa descontinuidade comum no conhecimento pela inteligência: "reestabeleceremos a continuidade no conjunto de nossos conhecimentos continuidade que não seria mais hipotética e construída, mas experimentada e vivida” (BERGSON, PM, p. 158, tradução nossa). Reestabelecer essa continuidade significa justamente compreender a indivisibilidade do movimento,

\footnotetext{
${ }^{28}$ C'est toujours d'un seul bond qu'un trajet est parcouru, quand il n'y a pas d'arrêt sur le trajet. Le bond peut durer quelques secondes, ou des jours, des mois, des années : peu importe. Du moment qu'il est unique, il est indécomposable. Seulement une fois le trajet effectué, comme la trajectoire est espace et que l'espace est indéfiniment divisible, nous nous figurons que le mouvement luimême est divisible indéfiniment.
} 
isto é, percebendo cada movimento como único e indivisível, e não como passível de uma fragmentação em infinitas partes. Ora, para isso é preciso recorrer à primeira distinção feita entre espaço homogêneo e tempo heterogêneo. A ilusão de que um movimento pode ser dividido em infinitas partes resulta de que sempre fazemos coincidir o movimento com o espaço, e não com o tempo. Perceber o movimento como divisível significa, no âmbito do conhecimento, introduzir uma descontinuidade na percepção da realidade que não é característica própria de uma realidade que é contínua, temporal. Isso ocorre justamente porque

Nós raciocinamos sobre o movimento como se ele fosse feito de imobilidades, e, quando o observamos, é com imobilidades que o reconstituímos. O movimento é para nós uma posição, e então uma nova posição e assim por diante indefinidamente ${ }^{29}$ (BERGSON, 2013b, p. 159, tradução nossa).

O problema é justamente conceber o movimento em termos de imobilidades, o que aparece como uma contradição, pois, sendo as partes imóveis, o todo constituído por essas partes não poderia ser o móvel. Essa contradição resulta da ilusão de que o movimento é decomponível, quando, na realidade, apenas o espaço o é. O movimento possui um aspecto temporal que é ignorado quando o pensamos como divisível:

A imobilidade sendo o que nossa ação precisa, transformamo-la em realidade, fazemos dela um absoluto, e vemos no movimento algo que se adiciona. Nada de mais legítimo na prática. Mas quando transportamos esse hábito de espírito para o domínio da especulação, desconhecemos a verdadeira realidade, criamos, de bom grado, problemas insolúveis, fechamos os olhos àquilo que há de mais vivo e de mais real ${ }^{30}$ (BERGSON, 2013b, p. 160, tradução nossa).

\footnotetext{
${ }^{29}$ Nous raisonnons sur le mouvement comme s'il était fait d'immobilités, et, quand nous le regardons, c'est avec d'immobilités que nous le reconstituons. Le mouvement est pour nous une position, puis une nouvelle position, et ainsi de suite indéfiniment.

${ }^{30}$ L'immobilité étant ce dont notre action a besoin, nous l'érigeons en réalité, nous en faisons un absolu, et nous voyons dans le mouvement quelque chose qui s'y surajoute. Rien de plus légitime dans la pratique. Mais lorsque nous transportons cette habitude d'esprit dans le domaine de la spéculation, nous méconnaissons la réalité vraie, nous créons, de gaieté de cœur, des problèmes insolubles, nous fermons les yeux à ce qu'il y a de plus vivant et de réel.
} 


\section{2}

\section{A ilusão da simultaneidade}

A partir do problema do movimento, Bergson introduz uma crítica à ilusão da noção da simultaneidade no Ensaio ${ }^{31}$. O objetivo é o desfazer a crença de que o movente se constitui por imobilidades e, em seguida, demonstrar que essa crença leva a uma ilusão sobre a simultaneidade que é parte de uma concepção errônea que temos do tempo. Para tanto, os paradoxos de Zenão são a base de uma argumentação contra a ilusão de um movimento concebido somente no espaço e não no tempo.

Para expressar a ideia de uma duração pura, Bergson usa em vários momentos de sua obra a analogia de um ser vivo dotado de um corpo "cujas partes, embora distintas, se penetram pelo efeito mesmo de sua solidariedade" (BERGSON, 2013a, p. 75, tradução nossa). Essa analogia é o que permite que compreendamos os nossos dados imediatos da consciência no âmbito da duração pura. Quando concebemos a consciência fora dos termos impostos pelo espaço, o que se apresenta a nós é justamente uma interpenetração solidária dos dados da consciência, isto é, a concepção de uma sucessão sem distinção entre as partes:

Podemos conceber então, a sucessão sem a distinção, e, como uma penetração mútua, uma solidariedade, uma organização íntima de elementos, na qual cada um, representativo do todo, apenas se distingue e se isola por um pensamento capaz de abstrair ${ }^{33}$ (BERGSON, 2013a, p. 75, tradução nossa).

Nesse sentido, podemos deduzir duas teses opostas, a primeira sendo a visão do tempo como separado do espaço, que seria a perspectiva correta de se conceber o tempo filosoficamente; a outra diz respeito a uma concepção errônea do tempo, impregnada de espaço e, portanto, confusa:

\footnotetext{
${ }^{31}$ Mais precisamente no segundo capítulo, em uma seção intitulada "Le mouvement est-il mesurable?".

${ }^{32} \mathrm{Ne}$ pourrait-on pas dire que, si ces notes se succèdent, nous les apercevons néanmoins les unes dans les autres, et que leur ensemble est comparable à un être vivant, dont les parties, quoique distinctes, se touchent sans se pénétrer par l'effet même de leur solidarité ?

${ }^{33}$ On peut donc concevoir la succession sans la distinction, et comme une pénétration mutuelle, une solidarité, une organisation intime d'éléments, dont chacun, représentatif du tout, ne s'en distingue et ne s'isole que pour une pensée capable d'abstraire.
} 
i. Quando pensamos em duração, isto é, em uma concepção pura do tempo, podemos conceber a sucessão de dados da consciência sem distinção.

ii. Por outro lado, quando temos uma visão do tempo impregnada de espaço, percebemos esses estados de consciência simultaneamente "não mais um dentro do outro, mas um ao lado do outro".

O exemplo escolhido para ilustrar essa ideia é o de um ponto A que se move em uma linha reta:

Se esse ponto tomasse consciência dele mesmo, ele se sentiria mudar, pois ele se move: ele perceberia uma sucessão; mas essa sucessão revestiria para ele a forma de uma linha? Sim, sem dúvida, à condição que ele pudesse se elevar, de alguma forma, sobre essa linha que ele percorre e perceber simultaneamente vários pontos justapostos: mas por aí mesmo ele formaria uma ideia de espaço, e é nesse espaço que ele veria se desenrolar as mudanças que ele sofre, e não na duração pura $^{34}$ (BERGSON, 2013a, p. 77, tradução nossa).

$\mathrm{Na}$ diferença de natureza entre duração e espaço, deduz-se a teoria das multiplicidades: por um lado, a duração é uma multiplicidade qualitativa (caracterizada pela sucessão dos dados imediatos, ou seja, as sensações que percebemos sem mediação do espaço, imediatamente pelo tempo da consciência) e, por outro, o espaço é multiplicidade quantitativa (o que existe no espaço são elementos numéricos, descontínuos e simultâneos). Embora a duração seja sucessão, continuidade, ela é múltipla. Dizer que a duração é multiplicidade qualitativa não significa dizer que ela é composta de unidades que a constituem (isso equivaleria ao que Bergson chama de multiplicidade quantitativa). A duração pode ser definida em termos de uma sucessão contínua (que a torna múltipla) em intensidades que diferem em natureza, ou seja, qualitativamente, e não quantitativamente (o que equivaleria a uma diferença de grau). $\mathrm{O}$ que existe fora da duração, isto é, no espaço, é a pura simultaneidade dos objetos, que só é possível de direito, mas não de fato, pois todo acesso ao espaço pressupõe uma consciência que dura e que, por meio da percepção, concebe essa simultaneidade

\footnotetext{
${ }^{34} \mathrm{Si}$ ce point prenait conscience de lui-même, il se sentirait changer, puisqu'il se meut: il apercevrait une succession; mais cette succession revêtirait-elle pour lui la forme d'une ligne? Oui, sans doute, à condition qu'il pût s'élever en quelque sorte au-dessus de la ligne qu'il parcourt et en apercevoir simultanément plusieurs points juxtaposés : mais par là même il formerait l'idée d'espace, et c'est dans l'espace qu'il verrait se dérouler les changements qu'il subit, non dans la pure durée.
} 
no fio do tempo, como sucessão. Há mudança no espaço, mas os momentos sucessivos da mudança só existem para uma consciência que rememora e que dura. ${ }^{35}$

Voltando ao exemplo do ponto A que percorre uma trajetória, esta concepção errônea ocorre, mais uma vez, pela dificuldade de chegarmos a uma ideia de tempo puro (duração): pensamos a consciência como algo espacial e, portanto, pensamos que é possível que haja simultaneidade entre estados dessa consciência. O que Bergson tenta nos mostrar é que, nesse momento, a duração é a própria consciência, e, sendo a duração o tempo puro, a simultaneidade só é possível no espaço. Não é possível, portanto, haver simultaneidade entre estados da consciência, apenas a ideia de uma sucessão sem distinção (pois a simultaneidade implica na ideia de distinção). A definição de duração pura fica então um pouco mais clara ao afirmar que é justamente quando o nosso eu "se abstém de estabelecer uma separação entre o estado presente e os estados anteriores" (BERGSON, 2013a, p. 75, tradução nossa). Essa abstenção significa conceber sucessão sem distinção entre estado presente e passado.

É esse o ponto de partida no qual se baseia toda a crítica à ilusão da simultaneidade e, paralelamente, a ideia de que o movimento, quando não confundido com o espaço, não seria mensurável. É somente superando essa ilusão que é possível acessar imediatamente a realidade do presente. A confusão entre tempo heterogêneo e espaço homogêneo tem como intermediária a ilusão da simultaneidade, que consiste em unir a duração interna aos instantes independentes, existentes no espaço. Bergson apresenta o exemplo das badaladas de um relógio para expressar essa confusão - a função do relógio é contar simultaneidades, e não a duração:

É porque eu duro dessa maneira que eu me represento o que chamo de oscilações
passadas do pêndulo, ao mesmo tempo que eu percebo as oscilações atuais. Ora,
suprimamos por um instante o eu que pensa essas oscilações ditas sucessivas; não
haverá jamais apenas uma oscilação do pêndulo, uma única posição desse
pêndulo, nenhuma duração, por conseguinte. Suprimamos, de outra parte, o
pêndulo e as oscilações; haverá tão somente a duração heterogênea do eu, sem
momentos exteriores uns aos outros, sem relação com o número. Assim, no nosso
eu, há sucessão sem exterioridade recíproca; fora do eu, exterioridade sem
sucessão: exterioridade recíproca, pois a oscilação presente é radicalmente
distinta da oscilação anterior que não é mais; mas ausência de sucessão, pois a

${ }^{35}$ É a partir daí que, em Matéria e memória, Bergson estabelece a tese de uma coexistência entre passado e presente, lançando mão de uma teoria da virtualidade. 
sucessão existe somente para um espectador consciente que rememora o passado e justapõe duas oscilações ou seus símbolos em um espaço auxiliar ${ }^{36}$ (BERGSON, 2013a, p. 81, tradução nossa).

A simultaneidade é o ponto de interseção entre a realidade do eu, da consciência, sem o pêndulo com as badaladas do pêndulo, sem a consciência. Ela é, portanto, necessária no momento em que ocorre à percepção uma continuidade sonora dos instantes marcados pelo pêndulo, mas inexistente quando um dos lados desse evento é isolado do outro. Bergson chamará de "tempo homogêneo" a esse tempo percebido por essa simultaneidade: “Graças à lembrança que nossa consciência organizou de seu conjunto, elas se conservam e então se alinham: em suma, criamos para ela uma quarta dimensão do espaço, que chamamos de tempo homogêneo ${ }^{37 "}$ (BERGSON 2013a, p. 81, tradução nossa). Na medida em que nossa percepção da continuidade das batidas de um relógio ou de um pêndulo depende da ilusão de uma simultaneidade possível, concebemos o tempo como homogêneo, e não como heterogêneo. Esse tempo não tem uma existência própria, singular, mas é um misto entre um tempo heterogêneo e a homogeneidade do espaço, o que é possibilitado pela simultaneidade: “A duração toma assim a forma ilusória de um meio homogêneo, e a ligação entre esses dois termos, espaço e duração, é a simultaneidade, que poderíamos definir como a interseção do tempo com o espaço" ${ }^{38}$ (BERGSON, 2013a, p. 82).

O mesmo raciocínio explica a concepção equivocada que temos do movimento: o deslocamento de um objeto entre dois pontos ocorre no espaço “mas a operação pela qual ele passa de uma posição à outra, operação que ocupa a duração e que apenas tem realidade por um espectador consciente, escapa ao

\footnotetext{
${ }^{36} \mathrm{C}$ 'est parce que je dure de cette manière que je me représente ce que j'appelle les oscillations passées du pendule, en même temps que je perçois l'oscillation actuelle. Or, supprimons pour un instant le moi qui pense ces oscillations dites successives; il n'y aura jamais qu'une seule oscillation du pendule, une seule position même de ce pendule, point de durée par conséquent. Supprimons, d'autre part, le pendule et ses oscillations ; il n'y aura plus que la durée hétérogène du moi, sans moments extérieurs les uns aux autres, sans rapport avec le nombre. Ainsi, dans notre moi, il y a succession sans extériorité réciproque; en dehors du moi, extériorité réciproque sans succession : extériorité réciproque puisque l'oscillation présente est radicalement distincte de l'oscillation antérieure qui n'est plus; mais absence de succession puisque la succession existe seulement pour un spectateur conscient qui se remémore le passé et juxtapose les deux oscillations ou leurs symboles dans un espace auxiliaire.

${ }^{37}$ Grâce au souvenir que notre conscience a organisé de leur ensemble, elles se conservent, puis elles s'alignent: bref, nous créons pour elles une quatrième dimension de l'espace que nous appelons le temps homogène (...).

${ }^{38}$ La durée prend ainsi la forme illusoire d'un milieu homogène, et le trait d'union entre ces deux termes, espace et durée, est la simultanéité, qu'on pourrait définir l'intersection du temps avec l'espace.
} 
espaço"39 (BERGSON, 2013a, p. 82). Em um mundo sem consciência, há apenas simultaneidades - na medida em que uma consciência é introduzida nesse mecanismo, a simultaneidade se torna uma mera ilusão a partir da qual deduzimos o tempo homogêneo e perdemos acesso à duração pura. Em suma, a sucessão das badaladas do pêndulo ocorre na consciência que dura, e não no espaço.

\section{3}

\section{A realidade do presente}

\subsection{1}

\section{O presente e os "dados imediatos"}

Uma vez estabelecida a diferença de natureza existente entre duração e espaço, surge a questão da relevância do Ensaio para responder à pergunta geral sobre como é possível um conhecimento de uma realidade que é, essencialmente, mudança. Em A percepção da mudança, toda a possibilidade de haver um "substrato" para tal mudança é excluída: "Há mudanças, mas não há, sob a mudança, coisas que mudam: a mudança não precisa de um suporte. Há movimentos, mas não há objetos inertes, invariáveis, que se movem: o movimento não implica um móvel"40 (BERGSON, 2013b, p. 163, tradução nossa).

Sendo o Ensaio uma investigação sobre os "dados imediatos da consciência", o presente é, por excelência, a dimensão temporal que diz respeito a esse exame. O próprio do tempo sendo a sua passagem, o presente pode ser visto apenas como ideal. Há uma exceção em que o presente, de fato, existe, que é no caso da concepção de eventos simultâneos. Embora a fugacidade do presente seja esse próprio presente, isso não significa que ele não seja real e passível de conhecimento. Se seguirmos as teses e as indicações do Ensaio, esse conhecimento é imediato. Ora, se o simultâneo e o imediato compõem o presente,

\footnotetext{
${ }^{39}$ Or, en réfléchissant davantage on verra que les positions successives du mobile occupent bien en effet de l'espace, mais que l'opération qui occupe la durée et qui n'a de réalité que pour un spectateur conscient, échappe à l'espace.

${ }^{40}$ Il y a des changements, mais il n'y a pas, sous le changement, des choses qui changent: le changement n'a pas besoin d'un support. Il y a des mouvements, mais il n'y a pas d'objet inerte, invariable, qui se meuve : le mouvement n'implique pas un mobile.
} 
é preciso passar então para uma compreensão da simultaneidade enquanto tal, e não apenas como é compreendida, ilusoriamente, em termos de um acontecimento que ocorre ao mesmo tempo em dois lugares diferentes do espaço.

A realidade do presente só pode ser conhecida em um ponto de síntese entre uma multiplicidade qualitativa (duração) e uma multiplicidade quantitativa na qual é possível uma simultaneidade de direito, mas não de fato.

\subsection{2 \\ Simultaneidade e realidade do presente}

Embora a ideia de uma ilusão da simultaneidade já esteja presente no Ensaio, é apenas em Duração e simultaneidade (1922) que essa ilusão parece tomar uma forma mais clara e uma explicação mais concreta através da qual Bergson encontra a forma mais exemplar da ilusão de que é possível haver dois eventos simultâneos, exteriores a uma consciência. É também na junção desses dois momentos que será possível analisar o que seria a realidade do presente e, consequentemente, o conhecimento dessa realidade. Em Duração $e$ simultaneidade, mais precisamente no terceiro capítulo da obra, Bergson propõe analisar a origem psicológica do conceito de simultaneidade em dois momentos: o primeiro, a partir da questão da simultaneidade dos fluxos, e o segundo (mais abstrato), a partir da simultaneidade de instantes.

No primeiro caso, a simultaneidade de fluxos se refere à coexistência do que é exterior à consciência (espaço) e da própria consciência (duração interna). A ideia de fluxo diz respeito a dois eventos que ocupam a mesma duração - a da consciência:

\footnotetext{
Essa é a nossa primeira ideia de simultaneidade. Chamamos então de simultaneidade dois fluxos externos que ocupam a mesma duração pois eles estão contidos, ambos, na duração de um terceiro, a nossa: essa duração só é a nossa quando nossa consciência se volta para nós, mas ela se torna igualmente a deles quando nossa atenção abraça os três fluxos em um ato indivisível ${ }^{41}$ (BERGSON, 2009, p. 51, tradução nossa).
}

\footnotetext{
${ }^{41}$ Telle est notre première idée de simultanéité. Nous appelons alors simultanés deux flux extérieurs qui occupent la même durée parce qu'ils tiennent l'un et l'autre dans la durée d'un troisième, la nôtre : cette durée n'est que la nôtre quand notre conscience ne regarde que nous, mais elle devient également la leur quand notre attention embrasse les trois flux dans un acte indivisible.
} 
A ideia dos três fluxos diz respeito, mais precisamente, ao exemplo empregado por Bergson de uma consciência - um eu - à beira de um rio, escutando o barulho do fluxo da água, dos pássaros em volta do rio ${ }^{42} \mathrm{e} o$ "murmúrio ininterrupto de nossa vida profunda". Por um lado, podemos conceber os três fluxos como separados, independentes entre eles, mas podemos também interiorizá-los no todo de uma percepção única que os une. Mas a exteriorização de cada um depende de uma consciência que dura, o que torna a simultaneidade entre eles impossível no espaço apenas, mas concebível para uma consciência. Sendo assim, a simultaneidade não é possível entre dois objetos independentes de uma consciência que dura, mas é possível entre eles para essa consciência.

A simultaneidade deve, portanto, supor um evento para uma consciência e, então, coexistir com ela. A realidade do momento presente implica uma abstração da simultaneidade externa (que é, portanto, ilusória) para coincidir com cada momento da duração interna. Sendo esta multiplicidade qualitativa (isto é, heterogênea), cada momento difere do outro em natureza, e não em grau, sendo, assim, o conhecimento necessariamente imediato, visto que há uma única chance para que ele aconteça: no presente.

A ideia desse conhecimento imediato do momento presente é elaborada em mais detalhes sob o nome de uma teoria da percepção pura, em Matéria e memória. A percepção pura é justamente uma coincidência entre conhecimento do objeto e o objeto, isto é, um conhecimento imediato do objeto. No entanto, é ao introduzir a questão da memória na percepção que Bergson atinge um ponto mais plausível sobre o conhecimento que ainda não está presente no Ensaio, visto que ele afirmará que toda percepção é impregnada de memória.

Conceber uma simultaneidade em termos de fluxos é mais provável do que pensá-la em termos de instantes, pois “o tempo real não saberia, portanto, fornecer o instante, este vem de um ponto matemático, isto é, do espaço" ${ }^{43}$ (BERGSON,

\footnotetext{
${ }^{42}$ Quand nous sommes assis au bord d'une rivière, l'écoulement de l'eau, le glissement d'un bateau ou le vol d'un oiseau, le murmure interrompue de notre vie profonde sont pour nous trois choses différentes ou une seule, à volonté. Nous pouvons intérioriser le tout, avoir affaire à une perception unique qui entraîne, confondus, les trois flux dans son cours ; alors notre attention entre dans le dedans et dans le dehors; ou mieux encore, nous pouvons faire l'un et l'autre à la fois, notre attention reliant et pourtant séparant les trois écoulements, grâce au singulier privilège qu'elle possède d'être une et plusieurs.

${ }^{43}$ Le temps réel ne saurait donc fournir l'instant, celui-ci est issu du point mathématique, c'est-àdire de l'espace.
} 
2009, p. 52). Em uma analogia entre a duração e uma linha, caso a duração pudesse ser interrompida, o instante seria o equivalente a um ponto em uma linha reta. A simultaneidade só é possível no abstrato, isto é, na medida em que é exterior a uma consciência.

\subsection{3}

\section{A questão da presença}

A realidade do presente remete diretamente à ideia apresentada por Bento Prado Junior sobre a questão da presença em contraposição a uma crítica do negativo e da ausência em Bergson. Em $O$ pensamento e o movente, Bergson mostra a contradição em se atribuir menos à ideia de desordem do que à ideia de ordem, menos à ideia de nada do que a ideia de Todo. Nesse tipo de falso problema, falhamos em enxergar que na ideia de desordem (comumente definida como ausência de ordem) há a ideia de ordem mais a negação dessa ideia, o que faz com que haja mais informação na ideia de desordem (e não menos) do que na ideia de ordem. Esse é um exemplo de como Bergson leva adiante a sua crítica do negativo, que Bento Prado Junior define como uma "miragem da ausência" em contraposição a uma "ontologia da presença". Sua tese é apresentada da seguinte maneira: "A crítica da ideia do Nada tem como propósito fundamental desmascarar a ontologia, cujo módulo fundamental é a Repetição, para desvendar os fundamentos da duração como argumento de uma ontologia da presença" (PRADO JUNIOR, 1989, p. 41).

Bento Prado Junior menciona a importância da linguagem na descontinuidade de nosso conhecimento: ao funcionar por meio de conceitos rígidos, a linguagem ao ser pronunciada sempre dá um conceito obsoleto acerca real que é, por sua vez, mudança contínua. Entretanto, em sua análise sobre o conhecimento do presente em Bergson, o autor apresenta a ideia de que é justamente porque a linguagem é descontínua que também é possível uma “experiência pura, sem a mediação da linguagem" (Ibid., p. 71), sendo esse o propósito do Ensaio sobre os dados imediatos da consciência. Essa experiência pura seria o contato direto da intuição com o movente (o real), e ocorre sempre na 
dimensão do presente, ou seja, em uma coexistência do eu como o objeto. Essa coexistência é o que Bento Prado Junior chama de "presença", em oposição à ilusão ou "miragem da ausência", que resulta da concepção de falsos problemas, como a ideia de nada ou a ideia de desordem, conforme exemplificadas anteriormente. Sendo assim, a presença é a condição de possibilidade para a intuição, que é o contato direto entre a consciência e o objeto, conhecimento imediato e portanto, preciso sobre o real. 


\section{3 \\ O passado e a ilusão de uma localização física da lembrança}

No presente capítulo, nosso objetivo é discutir a ilusão de que há uma localização física da lembrança no corpo. Esse tema surge na obra Matéria e memória (1896) para introduzir o tema da existência de um passado puro na memória, diferente de uma concepção amplamente aceita de um passado em função de um presente, ou seja, da memória como uma faculdade de armazenamento de momentos presentes. Para demonstrar a hipótese da existência de um passado puro, Bergson introduz uma análise profunda de uma tese aceita pela ciência de sua época: a ideia de que há uma localização física das lembranças no cérebro. ${ }^{44}$ Dando sequência às principais teses apresentadas no Ensaio sobre os dados imediatos da consciência, principalmente no que diz respeito a uma concepção do tempo independente do espaço e da duração como o tempo da consciência, Bergson tentará compreender como a duração abrange o passado, e o faz refutando a tese biológica de que há uma localização física da lembrança no cérebro. Nosso objetivo é apresentar como Bergson refuta esta concepção em um diálogo com a psicologia e psicofísica da época, e como essa argumentação nos permite ter um conhecimento sobre a realidade do passado e contextualiza passado e presente no âmbito da duração.

Desenvolveremos o capítulo apresentando a importância do conceito de imagem em Matéria e memória. Em seguida, discutiremos o que significa o cérebro ser uma "imagem central", prosseguindo então para uma discussão sobre a função do corpo. Nesse ponto, introduziremos a tese das duas formas da memória: uma memória hábito e uma memória lembrança e, então, como esses conceitos se articulam para concluir que é ilusório supor uma localização física da lembrança e como a superação dessa ilusão permite um conhecimento da realidade do passado. Nossa hipótese é a de que, para compreender a diferença fundamental entre passado e presente, é preciso abrir mão da ilusão de que

\footnotetext{
${ }^{44}$ No artigo intitulado The memory of another past: Bergson, Deleuze and a new theory of time (2004), Al-Saji aponta para a existência de experimentos atuais que demonstram que o cérebro causa a ocorrência de lembranças. No entanto, a interpretação bergsoniana do experimento ainda permite que essa hipótese seja revista, na medida em que o cérebro é apenas órgão de seleção e análise, e não produtor de representações.
} 
lembranças têm uma localização física no corpo, ou, mais especificamente, no cérebro.

\section{1 \\ Considerações sobre o conceito de imagem}

Conforme analisado no Ensaio sobre os dados imediatos da consciência, há um caráter nitidamente dualista no movimento do bergsonismo: por exemplo, a oposição entre duração e espaço, entre mundo material e mundo da consciência. Esses dualismos persistem em Matéria e memória, mas sob outros termos - corpo e espírito -, como já indica o subtítulo da obra: "Ensaio sobre a relação do corpo ao espírito". O corpo é material e existe no espaço. O espírito, sendo temporal, existe na duração. A tentativa de resolver esse dualismo entre corpo e espírito ocorre na análise do cérebro como órgão central, conforme a definição do cérebro como um centro telefônico: "O cérebro não é outra coisa senão, em nossa opinião, uma espécie de central telefônica: seu papel é "efetuar a comunicação", ou fazê-la aguardar" ${ }^{45}$ (BERGSON, 2008, p. 26, tradução nossa). O cérebro seria então o órgão de comunicação entre o corpo e o espírito, mas ele mesmo fazendo parte do corpo que é também, por sua vez, imagem. O que precisa ser definido é qual a natureza desse cérebro e como essa comunicação é possível, por exemplo, entre estados de espírito e sua verbalização, entre intenções da consciência e sua realização por meio de ações práticas no mundo material.

Podemos antecipar que o que possibilita a ação do cérebro como centro de comunicação é o seu caráter de imagem, mais precisamente por ser uma "imagem central". Recorreremos então à introdução do conceito de imagem em Matéria e memória e à sua importância para o desenvolvimento da obra. A imagem é definida da seguinte maneira:

A matéria é, para nós, um conjunto de "imagens". E por imagem entendemos uma certa existência que é mais do que o idealista chama de representação, porém

\footnotetext{
${ }^{45}$ Le cerveau ne doit donc pas être autre chose, à notre avis, qu'une espèce de bureau téléphonique central. Son rôle est de « donner la communication » ou de la faire attendre.
} 
menos do que o realista chama de coisa - uma existência situada entre a "coisa" e a "representação". ${ }^{46}$ (BERGSON, 2008, p. 1, tradução nossa).

O conceito de imagem pode ser interpretado como uma mediação entre dois termos: a coisa (sólida e espacial, existente no mundo material) e a representação da coisa (não necessariamente fiel à coisa pois depende de uma percepção limitada, incompleta e individual). De acordo com Élie During ${ }^{47}$, "é um conceito por padrão, que tem a virtude de despolarizar desde o princípio a oposição entre ser e aparecer, marcando o ponto onde eles coincidem"48 (2014, p. 855, tradução nossa).

Podemos apontar duas consequências decorrentes de um mundo material concebido em termos de imagens. A primeira é a de que não se confere ao corpo um estatuto ontológico diferente daquele conferido à representação. Tanto uma representação quanto o corpo são imagens existentes no mundo. $\mathrm{O}$ mesmo acontece quando pensamos na 'coisa'. Tanto a coisa como a representação dessa coisa possuem, em Matéria e memória, o mesmo estatuto. O dualismo entre o subjetivo (representação da coisa) e objetivo (a própria coisa) apresentado no Ensaio se dilui em Matéria e memória para apresentar um sistema em que coisa e representação não diferem quando considerada apenas em termos de "imagens". Em outros termos, a coisa e a representação mental da coisa diferem apenas em grau, e não em natureza. Na análise de Frédéric Worms ${ }^{49}$,

Trata-se de compreender a diferença entre coisa e representação como uma diferença por assim dizer horizontal, no seio de um mesmo nível de realidade suposto por hipótese, o nível das "imagens" e fazendo intervir unicamente a singularidade do "corpo"”,50 (WORMS, 1997, p. 17, tradução nossa).

A segunda consequência diz respeito a uma tradicional primazia da realidade da coisa sobre a da representação. O mundo definido em termos de

\footnotetext{
${ }^{46}$ La matière est pour nous, un ensemble d' « images ». E par image nous entendons une certaine existence qui est plus que ce que l'idéaliste appelle une représentation, mais moins que ce que le réaliste appelle une chose - une existence située à mi-chemin entre la «chose " et la « représentation ».

${ }^{47}$ DURING, Élie. Présence et répétition: Bergson chez les phénoménologues. Critique, Paris, v. 11, n. 2003, p. 848-864, out. 2014.

${ }^{48} \mathrm{C}$ 'est un concept par défaut, qui a la vertu de dépolariser d'emblée l'opposition entre être et l'apparaître en marquant le point où ils coincident.

${ }^{49}$ WORMS, 1997. Introduction à Matière et mémoire.

${ }^{50}$ Il s'agit de comprendre la différence entre chose et représentation comme une différence pour ainsi dire horizontale, au sein d'un même niveau de réalité posé par hypothèse, celui des « images » et en faisant intervenir seulement la singularité du « corps ».
} 
imagens torna mais fluida a relação entre a realidade da coisa e a de sua representação. Ambas são reais, diferindo apenas em grau, não em natureza.

A partir da suposição de um mundo constituído por imagens, é possível então dar um primeiro passo para a resolução do dualismo aparentemente insolúvel entre idealismo e realismo. Essas duas teses seriam excessivas, visto que "é falso reduzir a matéria à representação que temos dela, é falso também fazer da matéria algo que produziria em nós representações, mas que seria de uma natureza diferente delas" $" 51$ (BERGSON, 2008, p. 1, tradução nossa). A imagem seria então um dado fundamental das teses apresentadas em Matéria e memória, uma espécie de "denominador comum", ou terreno comum entre a coisa e a representação da coisa, entre espírito e corpo, essencial ao objetivo do primeiro capítulo, que é o de compreender o que liga e o que separa o nosso conhecimento e a realidade das coisas. Segundo Bergson:

Se perguntar se o universo existe dentro de nosso pensamento ou fora dele é enunciar o problema em termos insolúveis, supondo que eles sejam inteligíveis; é se condenar a uma discussão estéril, na qual os termos pensamento, existência, universo serão necessariamente tomados por uma parte ou por outra, em sentidos diferentes. Para resolver o debate, é preciso encontrar primeiro um terreno comum onde a luta comece e, já que para uns e para outros nós só apreendemos as coisas sob a forma de imagens, é em função de imagens e imagens apenas que devemos formular o problema ${ }^{52}$ (BERGSON, 2008, p. 21, tradução nossa).

Em suma, podemos resumir que os pontos principais que concernem o conceito de imagem da seguinte maneira:

- O mundo material é feito de imagens, que são menos do que uma coisa em si, mas são mais do que uma representação.

- A imagem é o denominador comum entre conhecimento e mundo: não há uma diferença de natureza, mas apenas de grau, entre coisa e representação a coisa, visto que ambas são imagens.

\footnotetext{
${ }^{51}$ Il est faux de réduire la matière à la représentation que nous en avons, faux aussi de s'en faire une chose qui produirait en nous des représentations, mais qui serait d'une autre nature qu'elles. (BERGSON, 2008, p. 1)

${ }^{52}$ Se demander si l'univers existe dans notre pensée seulement ou en dehors d'elle, c'est donc énoncer le problème en termes insolubles, à supposer qu'ils soient intelligibles; c'est se condamner à une discussion stérile, où les termes pensée, existence, univers seront nécessairement pris de part e d'autre dans des sens tout différents. Pour trancher le débat, il faut trouver d'abord un terrain commun où la lutte s'engage, et puisque, pour les uns et pour les autres, nous ne saisissons les choses que sous formes d'images, c'est en fonction d'images et d'images seulement que nous devons poser le problème.
} 
- O meu corpo, pertencente ao mundo material, é também uma imagem.

\title{
3.1.1 O cérebro como imagem central
}

Uma vez definida a imagem (isto é, a totalidade do mundo material) é preciso passar para a análise do corpo e, mais precisamente, do cérebro. Bergson argumenta que o corpo faz parte do mundo material e é, portanto, imagem. No entanto, o cérebro, pertencendo ao corpo, é apresentado como um caso específico de imagem, pois ele é uma "imagem central". A singularidade de cada corpo, isto é, aquilo que torna cada corpo distinto dos outros, reside na posição que cada um dos corpos (ou imagens) assume em relação às outras imagens presentes no universo. O cérebro é um caso específico de imagem, pois é nele que se reúnem os movimentos centrípetos (as sensações, isto é, as forças que vem do exterior para o interior) e centrífugos (as ações, isto é, o movimento que vem do interior para o exterior):

\begin{abstract}
Examinemos então de mais perto o que acaba de se produzir. Eis as imagens que compõem o universo em geral, e então aquelas vizinhas ao meu corpo e enfim o meu corpo ele mesmo. Nesta última imagem, o papel habitual dos nervos centrípetos é de transmitir movimentos ao cérebro e à medula; os nervos centrífugos reenviam esse movimento à periferia ${ }^{53}$ (BERGSON, 2008, p. 16, tradução nossa).
\end{abstract}

A complexidade do cérebro permite a indeterminação, ou seja, a possibilidade de que entre uma sensação e uma ação haja um momento indeterminado, que é o momento da escolha. Há dois exemplos para ilustrar essa indeterminação:

i. $\quad$ o caso de ações voluntárias: nesse caso, determinado evento acontece e me afeta por meio de uma sensação (força centrípeta que me afeta do exterior para o interior). Até o momento em que decido agir no mundo com base nos dados da sensação recebida, posso deliberar, hesitar e escolher o curso da ação possível que executarei. Esse local da

\footnotetext{
${ }^{53}$ Examinons donc de plus près ce qui vient de se produire. Voici les images qui composent l'univers en général, puis celles qui avoisinent mon corps puis enfin mon corps lui-même. Dans cette dernière image, le rôle habituel des nerfs centripètes est de transmettre des mouvements au cerveau et à la moelle ; les nerfs centrifuges renvoient ce mouvement à la périphérie.
} 
hesitação é o cérebro, imagem central que permite a recepção de sensações e a devolução de ações no mundo.

ii. O caso de ações involuntárias ou "ações reflexas". Em termos fisiológicos, as ações reflexas não percorrem o caminho do cérebro, mas o caminho da medula espinhal. Por exemplo, quando toco um objeto muito quente, não há deliberação antes da ação de retirar a minha mão do objeto, evitando uma queimadura. O centro de ações, nesse caso, é nossa medula espinhal, que é um caminho mais curto do que o do cérebro e devolve uma ação no mundo quase que imediatamente, visando a sobrevivência.

A ideia do cérebro como centro encontra-se em um texto do autor francês Félix Ravaisson, anterior a Matéria e memória, que influenciou profundamente a investigação de Bergson ${ }^{54}$. O texto de 1838 intitulado De l'habitude ${ }^{55}$ (Sobre o Hábito) propõe que: quanto maior o grau de complexidade de um ser vivo, maior é o seu intervalo de indeterminação. Bergson parte dessa tese para ir mais longe: o ser humano, tendo atingindo um grau máximo de complexidade na escala dos seres vivos é, portanto, o único animal que hesita. Segundo Ravaisson:

\begin{abstract}
Mas se a reação é mais e mais afastada e independente da ação à qual ela responde, parece que, cada vez mais é preciso um centro que sirva de limite comum, onde uma chega e de onde a outra parte; um centro que regula cada vez mais e por ele mesmo, à sua maneira, em seu tempo, a relação cada vez menos imediata e necessária da reação que ele produz com a ação que ele sofreu" ${ }^{\text {"56 }}$ (RAVAISSON, 2007, p. 18, tradução nossa).
\end{abstract}

Uma vez o cérebro definido como uma imagem central, é preciso agora investigar a relação entre imagem e percepção, e isso é definido por meio das funções negativas e positivas do corpo.

\footnotetext{
${ }^{54}$ Em O pensamento e o movente (1932) Bergson dedica o último ensaio da obra a uma análise dos textos de Ravaisson. O ensaio tem como título "A vida e a obra de Ravaisson"

${ }^{55}$ RAVAISSON, Félix. De l'habitude. Paris: Éditions Allia, 2007.

${ }^{56}$ Mais si la réaction est de plus en plus éloignée et indépendante de l'action à laquelle elle répond, il semble que de plus en plus il faut un centre qui leur serve de commune limite, où l'une arrive et d'où l'autre parte ; un centre réglant de plus en plus et par lui même, à sa manière, en son temps, le rapport de moins en moins immédiat et nécessaire de la réaction qu'il produit avec l'action qu'il a subie.
} 


\section{2}

\section{Funções positivas e negativas do corpo}

Para compreender a relação entre o corpo e a função da percepção, o corpo é caracterizado de uma dupla maneira: primeiro, a partir de suas funções negativas, isto é, quais as funções que não são próprias do corpo, e a segunda, com base em suas funções positivas: as funções do corpo propriamente ditas. Essa distinção é importante, pois a tese que pretende ser provada é a de que o corpo não pode ser fonte de representações e, para isso, é preciso demonstrar as funções que não cabem ao corpo, ou, em outros termos de suas restrições e limitações.

1. definição negativa da função corpo: o corpo não é fonte de representações ou o corpo não produz representações.

2. definição positiva da função do corpo: o corpo é órgão de análise e seleção de imagens.

A definição negativa do corpo implica que, em um sistema em que o que existe são imagens, não é o mundo que existe no cérebro (ou corpo - nesse contexto, o cérebro é parte do corpo e é também uma imagem) sob a forma de uma representação, mas sim o cérebro que existe no mundo sob forma de uma imagem entre outras imagens. Sendo assim, o cérebro é então parte da imagem total do mundo. "É o cérebro que faz parte do mundo material, e não o mundo material que faz parte do cérebro" ${ }^{, 57}$ (BERGSON, 2008, p. 13, tradução nossa). O corpo é, então, apenas uma imagem entre outras imagens. Ele não pode produzir novas imagens em um universo onde tudo está interligado, pois isso seria o mesmo que afirmar que a parte poderia conter o todo. Segue-se disso que o corpo não pode ser a fonte produtora das representações - enquanto imagem, o corpo pode apenas produzir movimento e agir no mundo visto que o cérebro é uma imagem central que capta sensações e devolve movimentos no mundo por meio do corpo.

\footnotetext{
${ }^{57}$ C'est le cerveau qui fait partie du monde matériel, et non pas le monde matériel qui fait partie du cerveau (BERGSON, 2008, p. 13).
} 
A definição positiva do corpo advém da diferença entre a imagem-corpo e as outras imagens do mundo. Essa diferença se resume da seguinte maneira:

Meu corpo é, então, no conjunto do mundo material, uma imagem que age como as outras, recebendo e devolvendo movimento, com a única diferença que meu corpo parece escolher, em certa medida, a maneira como devolve o que ele recebe (...). Meu corpo, objeto destinando a mover objetos, é então um centro de ação; ele não poderia fazer nascer uma representação ${ }^{58}$ (BERGSON, 2008, p. 14 , tradução nossa).

O corpo é um centro de ação e o sistema nervoso central produz movimentos e movimentos apenas, justamente porque o próprio sistema é movimento. As ações possíveis pelo corpo são a seleção e a análise. O corpo é uma imagem diferenciada entre outras, pois tem essa função de seleção e análise: seleção e recorte de imagens do mundo e a análise para avaliar como será possível agir sobre elas. Isto seria o que chamamos de teoria positiva da percepção pura, pois selecionar e analisar enquanto funções do corpo coincidem com o que Bergson chama de percepção. Perceber consiste em selecionar e analisar, e é uma função que só é possível por meio de um corpo. Segundo Worms ${ }^{59}$ :

O momento central de todo o capítulo é então a teoria positiva da percepção pura, ou da "seleção das imagens" propriamente dita, que compreende uma teoria do papel objetivo do corpo e, especialmente do "cérebro" como instrumento de análise e de escolha permitindo a ação indeterminada do corpo ${ }^{60}$ (WORMS, 2007, p. 18, tradução nossa).

Repensando a relação entre a consciência e os objetos, surge a necessidade de formular uma teoria da percepção. A partir da constatação de que o universo é feito de imagens, Bergson pode concluir que entre uma representação e o objeto não há uma diferença de natureza, mas apenas de grau:

A percepção se assemelha a esses fenômenos de reflexão, que provêm de uma refração impedida; é como um efeito de miragem. Isso vem a dizer que há, para

\footnotetext{
${ }^{58}$ Mon corps est donc, dans l'ensemble du monde matériel, une image qui agit comme les autres, recevant et rendant du mouvement, avec cette seule différence que mon corps paraît choisir, dans une certaine mesure, la manière de rendre ce qu'il reçoit. (...) Mon corps, objet destiné à mouvoir des objets, est donc un centre d'action ; il ne saurait faire naître une représentation (BERGSON, 2008, p. 14).

${ }^{59}$ WORMS, F. Introduction à Matière et mémoire, 1997.

${ }^{60}$ Le moment central de tout le chapitre est alors la théorie positive de la perception pure, ou de la « sélection des images » proprement dite, qui comprend une théorie du rôle objectif du corps, et notamment du «cerveau» comme instrument d'analyse et de choix permettant l'action indéterminée du corps.
} 
as imagens, uma simples diferença de grau, e não de natureza, entre ser e ser conscientemente percebidas ${ }^{61}$ (BERGSON, 2008, p. 35, tradução nossa).

Se o corpo pode gerar ações e fazer recortes no mundo, há mais no mundo material do que na representação dele, e não menos. A representação é a imagem do mundo menos aquilo que não nos interessa, visto que a teoria da percepção de um corpo que visa agir no mundo é uma teoria pragmática. Esse seria o esquema daquilo que Bergson chama de percepção pura, isto é, uma percepção sem nenhuma influência da memória. Esse tipo de percepção "pura" só é possível de direito, mas não de fato, pois toda percepção é impregnada de memória. "De fato, não há percepção que não seja impregnada de lembranças. Aos dados imediatos e presentes de nossos sentidos, entremeamos mil e mil detalhes de nossa experiência passada"62 (BERGSON, 2008, p. 30, tradução nossa). A expressão "percepção pura" é utilizada de maneira teórica apenas para introduzir o funcionamento desse mundo de imagens para o leitor. Já no segundo capítulo de Matéria e memória, Bergson introduz a memória na percepção para se aproximar do funcionamento de fato da percepção, que é sempre impregnada de lembranças. Cabe ressaltar que há uma função totalmente pragmática do corpo: o uso da palavra "rôle" (papel do corpo) já implica que ele tem uma função específica a ser desempenhada: a seleção e a análise.

Para compreender então o funcionamento da memória, Bergson propõe uma análise da percepção pura baseada na hipótese do universo constituído por imagens e, em seguida, insere a questão da lembrança na percepção, unindo uma teoria da memória à explicação de nossa percepção consciente. Seguiremos agora apresentando qual é essa teoria da memória e como ela resulta em duas formas da memória. Prosseguiremos então com a demonstração da tese de que não há uma localização física da memória.

\footnotetext{
${ }^{61}$ La perception ressemble donc bien à ces phénomènes de réflexion qui viennent d'une réfraction empêchée; c'est comme un effet de mirage. Cela revient à dire qu'il y a pour les images une simple différence de degré, et non pas de nature, entre être et être consciemment perçues.

${ }^{62}$ En fait, il n'y a pas de perception qui ne soit imprégnée de souvenirs. Aux données immédiates et présentes de nos sens, nous mêlons mille et mille détails de notre expérience passée.
} 


\section{3 \\ Memória e duração: a realidade do passado}

\subsection{1}

Memória, lembrança e hábito: as duas formas da memória

Uma das hipóteses interpretativas de Matéria e memória é a de que a solução para o problema metafísico clássico da união entre a alma e o corpo (ou entre espírito e matéria nas palavras de Bergson) se soluciona por meio da inseparabilidade entre percepção (uma função do corpo) e memória. Contrária às teorias psicofísicas da época, a hipótese de Bergson é a de que a memória é uma faculdade do espírito por excelência, e não do cérebro: o cérebro seria apenas uma imagem dentre outras imagens, como parte do corpo, enquanto o espírito é a própria consciência conforme caracterizada no Ensaio sobre os dados imediatos da consciência.

Para demonstrar essa hipótese, há dois momentos distintos, porém complementares, em Matéria e memória. O segundo capítulo da obra traça o papel da memória como uma função psicológica e, a partir de exemplos biológicos, demonstra a impossibilidade de haver uma localização física da lembrança. Em seguida, Bergson apresenta um tema mais metafísico que diz respeito à "sobrevivência" das lembranças, ou seja, como elas podem existir sem depender de uma localização física. Conforme vimos anteriormente, se o cérebro é apenas uma imagem central dentre outras imagens, ele não pode então ser a fonte de representações pois sua função é a de executar ações no mundo. Mas há uma constatação empírica inegável: imagens e percepções passadas reaparecem para a nossa consciência. O fato de que somos capazes de rememoração é inegável, embora o corpo não possa ser a fonte de tais representações. Sendo assim, é preciso recorrer a um princípio independente do corpo para explicar a lembrança. As lembranças rememoradas têm uma autonomia com relação ao corpo no sentido de seu caráter imaterial. Por um lado, o corpo, objeto físico, não pode ser a origem de representações não-físicas, pois ambos diferem em natureza, e não em grau. Essa tese se estenderá ao assumir uma independência do passado 
em geral, mas, para isso, é preciso compreender de que modo é apresentada a memória, isto é, suas duas formas.

É com base nessa constatação empírica de que imagens e percepções passadas reaparecem à consciência que Bergson apresenta uma análise psicológica de duas formas da lembrança baseadas, por sua vez, em duas formas da memória. A base do argumento é o princípio fundamental da passagem do tempo. Quando rememoramos, as imagens aparecem em uma duração, isto é, em uma certa espessura do tempo que passa, e não aleatoriamente em uma ordem qualquer. Segundo Worms:

Não é possível, com efeito, supor que as imagens aparecem e desaparecem a cada instante, em um piscar perpétuo. O fato da memória se apoia então sobre o fato ainda mais primitivo do fluir do tempo. Tudo isso conduz então, por princípio, a supor uma memória independente ${ }^{63}$ (WORMS, 2007, p. 98, tradução nossa).

Embora essa afirmativa de uma memória independente seja consequência do fato de que o corpo, por ser uma imagem, não pode produzir imagens (problema da relação entre contido e conteúdo), ainda não há uma garantia de que é necessário que haja uma memória independente do corpo. O que torna possível a afirmativa de que uma memória motora dependente do corpo não seja suficiente para definir toda a conservação do passado? Isso é explicado por meio do exemplo do aprendizado de uma lição.

\subsection{2}

\section{O exemplo do aprendizado de uma lição:}

Para exemplificar a maneira como se consolida a memória, Bergson apresenta o célebre exemplo do aprendizado de uma lição. Quando aprendemos o conteúdo de uma lição de cor, repetimos a lição, decompomos suas partes para então memorizar o seu todo, reconstituindo as partes que foram decompostas. Há um processo de decomposição e recomposição, o que faz com que, uma vez a

\footnotetext{
${ }^{63}$ Il n'est pas possible en effet de supposer que les images apparaissent et disparaissent à chaque instant, dans un clignotement perpétuel. Le fait de la mémoire s'appuie donc sur le fait plus primitif encore de l'écoulement du temps. Tout cela conduit donc d'emblée, sans autre préambule, à supposer une mémoire indépendante.
} 
lição aprendida, um hábito tenha sido contraído: fruto das necessárias repetições para uma memorização completa da lição.

De modo semelhante à exposição de Félix Ravaisson, o hábito é, para Bergson, a evidência mínima para que seja possível se distinguir a atividade de um espírito. Para que essa lição aprendida de cor seja repetida, isso requer um esforço de rememoração, definido da seguinte maneira no texto de 1902 intitulado O esforço intelectual $l^{64}$ : "Concluamos por enquanto que o esforço de rememoração consiste em converter uma representação esquemática, cujos elementos se interpenetram, em uma representação imagética cujas partes se justapõem" ${ }^{65}$ (BERGSON, 2012, p. 199, tradução nossa).

Em outros termos, quando aprendemos uma lição de cor e esta lição precisa ser rememorada, é preciso um esforço voluntário para essa rememoração e, quando ela se conserva, ela se conserva com base em mecanismos motores. Isso significa que, uma vez que a lição for rememorada, ela sempre o será através dos mesmos mecanismos motores e, portanto, será recitada da mesma maneira, como um sistema fechado de informações. O nome dessa memória é justamente memória-hábito, pois apresenta todas as características da aquisição de um hábito: ela deve ser repetida e gravada em um mecanismo motor para ser memorizada e, então, para que seja recitada, precisamos ter acesso aos mesmos mecanismos motores que entraram em ação no ato da memorização.

Por outro lado, há o modo como cada leitura da lição se efetuou. Nos lembramos de tal ou tal leitura particular, das circunstâncias que envolveram essa leitura, e cada leitura diferente é um acontecimento único na vida de um indivíduo:

A imagem [da lição] se imprimiu da primeira vez na memória, já que todas as outras leituras constituem, por definição mesmo, lembranças diferentes. É como um acontecimento da minha vida: ele tem por essência carregar uma data, e não pode, consequentemente, se repetir ${ }^{66}$ (BERGSON, 2008, p. 84, tradução nossa).

\footnotetext{
${ }^{64}$ BERGSON, Henri. L'effort intellectuel. In: L'énergie spirituelle. Paris: Éditions Payot Et Rivages, 2012.

${ }^{65}$ Concluons pour le moment que l'effort de rappel consiste à convertir une représentation schématique, dont les éléments s'entrepénètrent, en une représentation imagée dont les parties se juxtaposent.

${ }^{66}$ L'image s'en est nécessairement imprimée du premier coup dans la mémoire, puisque les autres lectures constituent, par définition même, des souvenirs différents. C'est comme un événement de ma vie ; il a pour essence de porter une date, et de ne pouvoir par conséquent se répéter.
} 
Nesse caso, cada leitura da lição se inscreve espontaneamente, primeiro na minha memória e, em seguida, na minha vida individual. Não há a necessidade de repetições sucessivas para que as circunstâncias sejam retidas na memória: cada leitura da lição é uma leitura singular, pois se inscreveu em um instante diferente da minha individualidade. Não há, tampouco, a necessidade de decomposição e recomposição, pois a imagem dessa lembrança já é total e única, e não pode ser reproduzida indefinidamente.

$\mathrm{Na}$ análise de Worms: "Tudo se passa como se uma percepção se tornasse automaticamente uma lembrança sendo substituída no tempo, isto é, no desenrolar de uma história pessoal, tornando-se não somente a consciência ou a percepção de alguma coisa, mas de alguém" 67 (WORMS, 2007, p. 103, tradução nossa). Diferente de uma memória-hábito, o que temos nessa situação é o que Bergson chama de uma memória-lembrança.

\subsection{3 \\ Memória-hábito e memória-lembrança}

A principal diferença entre uma memória-hábito e uma memórialembrança é o fato de que, na primeira, sua existência depende da contração de uma repetição mecânica específica que possa ser reproduzida quantas vezes seja necessário. O órgão responsável por essa reprodução mecânica é o cérebro, que opera em conjunto com o sistema sensório-motor. Poderíamos levar essa tese um pouco adiante dizendo que a memória-hábito depende de uma atividade pragmática do corpo. No caso da lição isso significa a capacidade de reproduzir a lição aprendida por meio de repetições sucessivas. O problema das teses neurológicas (aquelas que julgam ser possível localizar fisicamente uma lembrança) é justamente conceber a lembrança como uma marca, falhando em identificar a existência de dois tipos de memória: a que se manifesta por meio do hábito e a que existe sob a forma de uma imagem-lembrança.

\footnotetext{
${ }^{67}$ Tout se passe comme si une perception devenait automatiquement un souvenir en étant remplacée dans le temps, c'est-à-dire dans le déroulement d'une histoire personnelle, en devenant non seulement la conscience ou la perception de quelque chose mais de quelqu'un.
} 
Quando os psicólogos falam da lembrança como uma dobra contraída, como uma impressão que se grava cada vez mais profunda e repetidamente, eles esquecem que a grande maioria de nossas lembranças dizem respeito a acontecimentos e detalhes de nossa vida, cuja essência é a de ter uma data e, consequentemente, nunca se reproduzir novamente ${ }^{68}$ (BERGSON, 2008, p. 88, tradução nossa).

É justamente por pensar que há apenas uma diferença de grau, e não de natureza, entre uma imagem-lembrança e um hábito que se chega à hipótese de que há uma localização da lembrança no cérebro. É a memória-hábito que deixa marcas no nosso sistema motor e que, assim sendo, pode ser repetida quantas vezes desejarmos. A lembrança sob a forma de hábito apresenta inevitavelmente um rastro material, e terá como modelo um pragmatismo essencialmente caracterizado pela função do corpo. A memória-lembrança, por sua vez, é espontânea. Devido ao fato de ser menos útil do que um hábito, ela só é possível na medida em que nos abstraímos da ação presente: "Para evocar o passado sob forma de imagem, é preciso poder se abstrair da ação presente, é preciso atribuir valor ao inútil, é preciso querer sonhar" ${ }^{69}$ (BERGSON, 2008, p. 87, tradução nossa).

Abstrair-se da ação presente significa, justamente, no âmbito de Matéria e memória, conceber uma existência independente do corpo e, consequentemente, aceitar a impossibilidade de haver uma localização física da lembrança no mesmo. Significa também se abstrair de um pragmatismo característico do corpo e da memória-hábito, pois a memória-lembrança não visa uma ação no mundo.

\subsection{4}

\section{Sobre o caráter não-físico da lembrança}

Embora tenha sido estabelecida uma nítida distinção entre cérebro e espírito, a imagem é justamente o conceito mediador que permite que a atividade do cérebro e a atividade do espírito se confundam. Isso se explica, em Matéria e memória, nas páginas que lidam com as afasias. Bergson utiliza o exemplo das

\footnotetext{
${ }^{68}$ Quand les psychologues parlent du souvenir comme d'un pli contracté, comme une impression qui se grave de plus en plus profondément en se répétant, ils oublient que l'immense majorité de nos souvenirs portent sur les évènements et détails de notre vie, dont l'essence est d'avoir une date et par conséquent de ne se reproduire jamais (BERGSON, 2008, p. 88).

${ }^{69}$ Pour évoquer le passé sous forme d'image, il faut pouvoir s'abstraire de l'action présente, il faut savoir attacher du prix à l'inutile, il faut vouloir rêver (BERGSON, 2008, p. 87).
} 
afasias (falhas da memória no que diz respeito à linguagem, à audição ou à visão) para demonstrar a relação entre uma lesão e uma função afetada por tal lesão.

Com base nos experimentos de Charcot, Broadbent, Kussmaul e Lichtheim, entre outros, Bergson investiga a relação entre lesões no córtex cerebral e afasias. Podem ser destacados dois tipos de deficiências ou cegueiras auditivas ou visuais. O primeiro diz respeito a casos em que as lembranças auditivas e verbais são evocadas (rememoradas), mas não se inserem na vida prática. Por exemplo, um paciente que lembra de sua língua materna ou de palavras escutadas sem conseguir repeti-las. O segundo diz respeito a um impedimento ou inabilidade de acessar as lembranças. No primeiro caso, o doente consegue preservar a lembrança de um som ou palavra, sem conseguir pronunciálo. No segundo caso, a própria lembrança não é preservada e o paciente não tem mais acesso a ela. Se fosse, no primeiro exemplo, o caso de uma lesão física de determinada área do cérebro, não seria possível que o paciente tivesse a lembrança de palavras e sons, visto que a área do cérebro afetada fisicamente não permitiria que o paciente tivesse sequer essas lembranças. Segue-se daí que:

À medida em que essas lembranças tomam a forma de uma representação mais completa, mais concreta e mais consciente, elas tendem ainda mais a se confundir com a percepção que as atrai ou das quais ela tomam a forma. Não há então, não pode haver no cérebro uma região onde as lembranças congelam e se acumulam. A pretendida destruição das lembranças por lesões cerebrais não é senão uma interrupção do progresso contínuo por meio do qual a lembrança se atualiza ${ }^{70}$ (BERGSON, 2008, p. 140, tradução nossa).

Em outras palavras, esses dois tipos de afasias dizem respeito à existência de dois tipos de memórias. Uma memória-hábito, como no segundo caso, depende de mecanismos motores e, uma vez que esses mecanismos são lesionados, a lembrança não pode mais ser evocada. No entanto, no primeiro caso, isso se refere a uma memória-lembrança, que é afetiva e que, portanto, embora os mecanismos motores relacionados a ela tenham sido danificados, a memória persiste.

Esse é o caso, por exemplo, de quando conhecemos uma língua e ouvimos determinada palavra ser pronunciada por vozes diferentes ou entonações ou

\footnotetext{
${ }^{70}$ À mesure que ces souvenirs prennent la forme d'une représentation plus complète, plus concrète et plus consciente, ils tendent d'avantage à se confondre avec la perception qui les attire ou dont ils adoptent le cadre. Donc il n'y a pas, il ne peut y avoir dans le cerveau une région où les souvenirs se figent et s'accumulent. La prétendue destruction des souvenirs par des lésions cérébrales n'est qu'une interruption du progrès continu par lequel le souvenir s'actualise.
} 
sotaques diferentes. A mesma palavra aprendida em determinada língua pode ser compreendida pelo mesmo sujeito pronunciada de maneiras diferentes. Se fosse o caso apenas de uma memória-hábito, isso não seria possível, pois apenas o mecanismo que ocorrera na hora do aprendizado da palavra seria armazenado. A conclusão que podemos tirar desses exemplos, e a que mais nos interessa é a seguinte: é possível determinar uma localização física apenas da memória-hábito, pois ela depende de uma inscrição no corpo, de um registro mecânico fruto de determinado número de repetições. Nesse caso, é possível relacionar lesões no córtex cerebral e corresponde-las com afasias. No entanto, quando compreendemos também que a memória também é lembrança, ou seja, como no exemplo do aprendizado da lição, uma memória única e que se apresenta total e unicamente da primeira vez em que entramos em contato com ela e ela já significa algo para nós, temos o caso de afasias que preservam a lembrança, mas que encontram uma impossibilidade na sua atualização para a vida prática.

Vladimir Jankélévitch (autor contemporâneo de Bergson e seu comentador) propõe uma análise importante sobre o problema das afasias. Em sua perspectiva, há uma diferença entre uma lesão e a função que deve ser executada:

\begin{abstract}
A lesão está no espaço, mas não a função. A função está no tempo. Essa distinção que opõe a consciência ao espaço? A função precisa, para se exercer, de um substrato anatômico, no sentido que sem órgãos, não haveria função possível (...). Observamos, de fato, que a maioria das doenças tão estudadas no século passado na época dos "localizadores" se caracterizam por problemas operatórios, pelo pânico e pelo desequilíbrio da melodia. São doenças do tempo - esse tempo que a presença de um cérebro capaz de esperar, de escolher, de olhar em direção ao futuro e de inserir ações humanas ${ }^{71}$ (JANKÉLÉVITCH, 2011, p. 91, tradução nossa).
\end{abstract}

\footnotetext{
${ }^{71}$ La lésion est dans l'espace, mais non la fonction. La fonction est dans le temps. Cette distinction insurmontable qui oppose la conscience à l'espace? La fonction a besoin, pour s'exercer, d'un substrat anatomique, en ce sens que sans organe, il n'y aurait pas de fonction possible; mais dans les tissus, la fonction n'a pas son siège ; aussi cette condition nécessaire de la pensée qu'on appelle un encéphale n'est-elle jamais suffisante! La fonction s'organise comme une mélodie dont les moments successifs adoptent un rythme de plus en plus complexe au fur et à mesure qu'il s'agit de tendances mieux intégrées. Et l'on observe, en fait, que la plupart des maladies si étudiées au siècle dernier à l'époque des «localisateurs" se caractérisent par des troubles opératoires, par l'affolement et le déséquilibre de la mélodie. Ce sont des maladies du temps - ce temps que la présence d'un cerveau capable d'attendre, de choisir et de regarder vers le futur insère dans les entreprises humaines. (JANKÉLÉVITCH, p. 91).
} 


\subsection{5 \\ Imaterialidade da lembrança e a existência de um passado puro}

Com base na distinção entre dois tipos de memória e, consequentemente, na distinção entre uma lembrança-hábito e uma imagem-lembrança, podemos sugerir a existência de um passado puro no contexto de Matéria e memória. A principal ideia que pretendemos demonstrar é a de que o passado só pode ser real na medida em que ele é independente do corpo, na medida em que ele existe em si, ou nos termos de Bergson, sob a forma de um passado puro. O conhecimento da realidade do passado depende também da impossibilidade de se haver uma localização física da lembrança no caso do segundo tipo de memória. Pela expressão "passado puro" compreende-se um passado cuja existência independe do corpo, ou seja, um passado que nunca foi vivido de fato corporalmente por uma memória localizável fisicamente no cérebro (uma instância independente do corpo) e que existe para além de uma rememoração psicológica. Esse passado, na análise de Keith Ansell Pearson, tem um "ser do passado", o que garante que seja possível uma ontologia própria a ele justamente por tratar-se de um passado puro. Segundo Pearson:

O que Bergson desvelou foi uma vida autônoma da memória. A memória está relacionada a hábitos corporais e às suas necessidades presentes, mas também usufrui de uma vida própria. Isso se deve ao fato de que a imagem não só representa o objeto da representação ou a percepção (a memória não simplesmente preserva os traços das coisas). A diferença essencial entre um objeto imagem e uma memória-imagem é a seguinte: enquanto a primeira está firmemente situada em um tempo sequencial, a última não o está; uma memória-imagem é uma imagem que foi removida do agregado de imagem e que agora faz parte de uma duração subjetiva ${ }^{72}$ (ANSELL-PEARSON, p. 174, tradução nossa).

A partir da argumentação que mostra a impossibilidade de se haver uma localização física da lembrança, deduz-se a hipótese de que, caso exista o passado, a sua existência deve ser independente do corpo e, do mesmo modo, operar por meio de imagens-lembranças, que por sua vez, dependem de uma duração

\footnotetext{
${ }^{72}$ What Bergson has uncovered is an autonomous life of memory. Memory is related to bodily habits and to present needs, but it also enjoys a life of its own. This is owing to the fact that the image does not simply represent the object of representation or perception (memory does not simply preserve traces of things). The essential difference between an object image and a memoryimage is as follows: whereas the former is firmly situated in a sequential time, the latter is not; a memory-image is an image that has been removed from the aggregate of images and is now part of a subjective duration.
} 
subjetiva, o que já havia sido especificado em Ensaio sobre os dados imediatos da consciência.

Ora, se o passado existe independente do corpo, mas há a memória-hábito que se expressa principalmente por meio de mecanismos motores, devemos nos perguntar qual o ponto de contato, a relação íntima que existe, entre corpo e memória e onde o passado então se insere no presente. Segundo Bergson, esse problema se resolve quando pensamos em uma coexistência do passado com o presente. Por coexistência compreende-se uma inseparabilidade entre memória e ação, sendo o presente sempre a atualização de uma ação prática no mundo. A ação é o ponto de contato em um passado e um porvir que se realiza por meio de um ato voluntário, embora ela ocorra de fato, mas não necessariamente de direito.

Em outras palavras, o que temos de fato é uma confusão entre diversos planos de existência dos mais abstratos ao mais prático, começando pelo plano do sonho, em seguida pelo da memória e, por último, pelo da ação presente, que depende intrinsecamente de um papel a ser desempenhado pelo corpo. O que temos de fato é uma memória que se confunde em todos esses planos de existência e que, portanto, nos leva a crer que ela é unicamente dependente do corpo. O objetivo central de Matéria e memória é o de nos mostrar o que de direito existe, isto é: dois planos da memória cuja atualização dependem do que Bergson chama de graus sucessivos de contração ou extensão dessas lembranças em uma dimensão do tempo independente do espaço, a saber, a duração.

Tudo se passa como se, em graus menores de tensão, o relaxamento da memória permite que tenhamos um acesso mais direto à memória-lembrança. Esse grau de relaxamento se relaciona com a falta de necessidade de um pragmatismo corporal quando, por exemplo, sonhamos ou rememoramos algo afetivamente, tal como as circunstâncias nas quais a lição foi aprendida, em oposição ao seu conteúdo pragmático.

Deste modo, é por graus sucessivos que se mostra uma necessidade de ação do mundo chegando ao ápice do pragmatismo do corpo a ação reflexa. Se retomarmos essa gradação no contexto da distinção fundamental entre tempo e espaço, temos que o campo em que a ação reflexa ocorre seria o domínio do espaço e os graus de menor tensão e maior relaxamento correspondem ao tempo puro. 
No entanto, justamente porque vida corporal e vida espiritual são inseparáveis, essa distinção não é clara, de fato, mas apenas de direito. O que se apresenta para o nosso entendimento são mistos entre os graus distintos da memória. No caso da ação reflexa, a memória é justamente a memória-hábito gravada nos mecanismos corporais por meio de decomposição, recomposição e repetições sucessivas.

\subsection{6 \\ A realidade do passado e sua coexistência com o presente}

A realidade de um passado puro pode ser concebida como independente do corpo, mas coexistente com o presente. Isso significa que o que conhecemos de fato é uma confusão constante entre a memória-hábito e a lembrança pura. Usando o exemplo do aprendizado da lição, justamente por nossa experiência do tempo ser confundida com a do espaço, temos dificuldade em distinguir o conteúdo da lição aprendida com as circunstâncias afetivas que nos tocaram na ocasião do aprendizado dessa mesma lição. No entanto, uma vez que seguirmos os passos para a compreensão de um tempo como duração, seguindo a mesma linha de pensamento apresentada no Ensaio sobre os dados imediatos da consciência, podemos ver em Matéria e memória que a desvinculação de uma lembrança a uma localização física no corpo (mais precisamente no cérebro) nos permite a compreensão de um passado puro, isto é, de um passado em sua dimensão própria, que difere em natureza com o presente, embora coexista com ele.

O passado puro é definido por Alia Al-Saji (no artigo intitulado Bergson, Deleuze and the memory of another past) da seguinte forma:

Isso significa dizer que a memória não é nem uma impressão passiva na mente, nem algo inerte e indiferente. A memória pura tem um certo poder [puissance] que não é o da causalidade eficiente, mas o da sugestão. O que a memória pura sugere - o que ela deseja expressar - não é uma cópia de si mesma no mundo, nem um correlato ou uma re-presentação de um presente da qual ela foi formada. Ao invés, o que é sugerido é uma tonalidade afetiva particular, um ritmo particular de um tornar-se, ou intensidade da memória, uma perspectiva única que caracteriza o plano da memória pura (AL-SAJI, 2005, p. 216, tradução nossa) ${ }^{73}$.

\footnotetext{
${ }^{73}$ It is to say that memory is neither a passive imprint on the mind nor an inert indifferent thing. Pure memory has a certain power (puissance) which is not that of efficient causality, but of suggestion. What pure memory suggests - what it desires to express - is not a copy of itself in the
} 
A questão da sugestividadade da memória é importante na medida em que justamente por não haver uma localização física da lembrança, a sua rememoração não é precisa, mas simplesmente possível em determinados graus de maior relaxamento ou tensão das camadas de duração características da multiplicidade qualitativa da consciência. Essa ideia de sugestão indica que a lembrança também não obedece à causalidade eficiente, o que nos leva a pensar esse funcionamento causal no âmbito de uma temporalidade mais ampla, como no contexto apresentado n'A evolução criadora (1907). Nesse caso, a causalidade no âmbito da evolução precisa ser repensada e retraçada em termos temporais, isto é, na duração, e não apenas em um desenvolvimento que ocorre no espaço. $\mathrm{O}$ tema da causalidade é então o que abordaremos no capítulo seguinte, com a intenção de demonstrar como as relações de causalidades pensadas a partir da duração permitem uma abordagem do porvir. suggested is a singular affective tonality, a particular rhythm of becoming or intensity of memory, a unique perspective that characterizes a plane of pure memory. 


\section{O porvir e a ilusão da causalidade}

A compreensão da ilusão da simultaneidade e o caráter não-físico da lembrança permitem, respectivamente, um acesso ao conhecimento do presente e do passado puro. O que pretendemos investigar agora é a possibilidade de um conhecimento do porvir - não de seu conteúdo, mas da possibilidade de haver um porvir criador e imprevisível no real intuído por Bergson. Para tanto, escolhemos o problema da ilusão da causalidade conforme ele é introduzido na obra de 1907: A evolução criadora. O principal objetivo da obra é o de tentar esclarecer, na perspectiva filosófica, as descobertas da teoria da evolução em suas diversas vertentes. A investigação sobre o conhecimento do porvir é, então, o terceiro momento constituinte de uma metafísica do movente.

Embora passado, presente e futuro possam ser analisados por meio da compreensão de falsos problemas que resultam em ilusões do nosso senso comum, é só na perspectiva do tempo puro, isto é, concebido independentemente do espaço, que será possível justapor essas três temporalidades em uma só: a duração. A separação entre presente, passado e porvir é uma separação artificial no Todo da duração. No entanto, cabe ressaltar, esses três "momentos" correspondem a críticas precisas nas obras que propomos analisar, embora as três ilusões analisadas pertençam ao problema mais geral de uma concepção do tempo misturada ao espaço.

A nossa hipótese é a de que um conhecimento do porvir depende de uma compreensão do conceito de causalidade diferente da noção clássica de uma relação direta entre uma causa $\mathrm{A}$ e seu efeito $\mathrm{B}$, na qual o efeito está inteiramente contido em sua causa. O conhecimento do porvir se refere à possibilidade de prever eventos futuros, mas sim poder compreender qual a relação de um tempo futuro com relação à consciência e ao conceito mais amplo de duração.

Quando nos referirmos ao termo "causalidade", compreende-se uma relação entre uma causa A e seu efeito B: essa relação pode ser formulada como "A é a causa de B" ou "B resulta diretamente de A". Por meio de uma análise de teses presentes na biologia de seu tempo e em especial como repercussão da Origem das espécies de Darwin, A evolução criadora, indiretamente, rejeita essa concepção de causalidade no que diz respeito ao ser vivo. Uma das consequências 
diretas dessa concepção era a possiblidade de estabelecer uma previsibilidade entre determinadas causas e efeitos quanto maior fosse o número de observações de seu mesmo encadeamento. O principal objetivo de Evolução criadora é a conciliação entre uma metafísica concreta e um conhecimento biológico no âmbito de uma filosofia da duração. Logo nas páginas iniciais da obra, é apresentada a tese de que uma teoria do conhecimento deve ser inseparável de uma teoria da vida:

É dizer que uma teoria do conhecimento e uma teoria da vida nos parecem inseparáveis uma da outra. Uma teoria da vida que não se acompanha de uma teoria do conhecimento é obrigada a aceitar, tais quais, os conceito que o entendimento coloca à sua disposição. (...) É preciso que essas duas pesquisas, teoria da vida e teoria do conhecimento, se encontrem, e, por um processo circular, se impulsionem uma à outra indefinidamente ${ }^{74}$ (BERGSON, 2013, p. IX, tradução nossa).

Ainda nas considerações iniciais, temos uma retomada da definição de duração conforme concluída em Matéria e memória: “a duração é o progresso contínuo do passado que rói o porvir e que cresce ao avançar ${ }^{75}$ " (BERGSON, 2013c, p.4, tradução nossa). Nossa principal análise se baseará nesse "avanço" da duração sobre o porvir. Essa distinção é retomada n'A evolução criadora quando Bergson mostra a distinção entre os sistemas artificialmente recortados pela ciência e o que ele chama de sistemas naturais.

A ciência, tendo como atividade principal prever e antecipar, escolhe artificialmente, como parte intrínseca do seu método, um grupo de elementos sobre o qual traçará sua investigação. Sendo assim, a ciência não concebe um todo que dura, mas elementos em que o passado e o porvir dependem intrinsecamente de um presente analisado pontualmente.

No entanto, na perspectiva bergsoniana, a evolução tem um caráter criador e imprevisível evidentes, o que torna impossível compreendê-la da forma proposta pelo método científico. É preciso haver uma compreensão filosófica da evolução como contínua e criadora, mas, na visão biológica, ela pode apenas ser concebida

\footnotetext{
${ }^{74} \mathrm{C}$ 'est dire qu'une théorie de la connaissance et une théorie de la vie nous paraissent inséparables l'une de l'autre. Une théorie de la vie qui ne s'accompagne pas d'une théorie de la connaissance est obligée d'accepter, tels quels, les concepts que l'entendement met à sa disposition (...) Il faut que ces deux recherches, théorie de la connaissance et théorie de la vie, se rejoignent, et par un processus circulaire, se poussent l'une à l'autre indéfiniment.

${ }^{75} \mathrm{La}$ durée est le progrès continu du passé qui ronge l'avenir et qui gonfle en avançant.
} 
como pontual, descontínua e fruto de um conhecimento por análise ${ }^{76}$. Isso se deve, em grande parte, à nossa crença em um princípio fundamental que torna essa repetição possível, a saber, o princípio de causalidade. Mais uma vez, não se trata de tentar restringir a ciência em detrimento de uma superioridade da filosofia. Muito pelo contrário, isso significa compreender o campo de atuação da ciência e suas abrangências e limitações, mas também incluir a investigação filosófica em questões unicamente tratadas pela ciência até então, como, por exemplo, o tema da evolução das espécies. Toda a investigação apresentada em $A$ evolução criadora faz parte de um projeto mais amplo de um resgate da metafísica, tentando apresenta-la sob novos termos, isto é, pensar a metafísica como experiência integral ${ }^{77}$, conforme antecipamos na introdução do presente trabalho.

\footnotetext{
${ }^{76} \mathrm{O}$ conhecimento por análise se opõe ao conhecimento por intuição. A análise requer um contato com o objeto mediado pelas formas da inteligência, isto é: acessa o objeto indiretamente, imobilizando-o e enrijecendo-o, extraindo dele a sua parte imóvel e ignorando o seu caráter de mudança contínua. Por outro lado, a intuição conhece o objeto imediatamente, trata-se de uma coexistência do sujeito com o objeto. Essa distinção é principalmente apresentada no ensaio intitulado Introdução à metafísica, parte da coletânea de ensaios $O$ pensamento e o movente: "É dizer que a análise opera sobre o imóvel, enquanto a intuição se posiciona na mobilidade ou, o que é o mesmo, na duração. Aí está a linha de demarcação bem nítida entre a intuição e a análise. Reconhecemos o real, o vivido o concreto ao que ele é a variabilidade mesma. E ele é invariável por definição, sendo um esquema, uma reconstrução simplificada, frequentemente um simples símbolo, em todo caso, uma vista tomada sobre a realidade que escorre." (BERGSON, 2013b, p. 202, tradução nossa) No original : "C'est dire que l'analyse opère sur l'immobile, tandis que l'intuition se place dans la mobilité ou, ce qui revient au même, dans la durée. Là est là ligne de démarcation bien nette entre l'intuition et l'analyse. On reconnaît le réel, le vécu, le concret, à ce qu'il est la variabilité même. Et il est invariable par définition, étant un schéma, une reconstruction simplifiée, souvent un simple symbole, en tout cas, une vue prise sur la réalité qui s'écoule. »

${ }^{77}$ A concepção de metafísica como experiência integral é postulada em Introdução à metafísica por oposição a uma concepção clássica da metafísica como generalização da experiência: "Os mestres da filosofia moderna foram homens que haviam assimilado todo o material da ciência de seu tempo. E o eclipse parcial da metafísica há meio século tem sobretudo como causa a extraordinária dificuldade que o filósofo experimenta hoje em tomar contato com uma ciência que se tornou muito mais difusa. Mas a intuição metafísica, embora não possamos chegar nela senão por meio de conhecimentos materiais, é outra coisa do que o resumo ou a síntese desses conhecimentos. Ela se distingui como o impulso motor do caminho percorrido pelo móvel, como a tensão da mola se distingue dos movimentos visíveis no pêndulo. Nesse sentido a metafísica nada tem em comum com a generalização da experiência, e contudo ela poderia se definir como $a$ experiência integral." (BERGSON, 2013b, p. 227, tradução nossa). No original: «Les maîtres de la philosophie moderne ont été des hommes qui s'étaient assimilé tout le matériel de la science de leur temps. Et l'éclipse partielle de la métaphysique depuis un demi-siècle a surtout pour cause l'extraordinaire difficulté que le philosophe éprouve aujourd'hui à prendre contact avec une science devenue beaucoup plus éparpillée. Mais l'intuition métaphysique, quoiqu'on n'y puisse arriver qu'à force de connaissances matérielles, est tout autre chose que le résumé ou la synthèse de ces connaissances. Elle s'en distingue comme l'impulsion motrice se distingue du chemin parcouru par le mobile, comme la tension du ressort se distingue des mouvements visibles dans la pendule. En ce sens, la métaphysique n'a rien de commun avec une généralisation de l'expérience, et néanmoins elle pourrait se définir l'expérience intégrale. »
} 
Se, em oposição aos sistemas artificiais, considerarmos os sistemas naturais, isto é, aqueles que não foram recortados artificialmente em elementos semelhantes e isolados entre si, mas que existem no Todo do universo, em uma única duração, então a crença na existência de relações causais se torna problemática. Nesse capítulo, apresentaremos qual é exatamente o problema da causalidade e o aparato crítico que o acompanha em duas possíveis explicações da evolução: as explicações mecanicistas e as explicações finalistas. Mostraremos também porque Bergson rejeita ambas, embora tente resgatar uma parcela de finalismo, em nossa hipótese, por meio da noção de élan vital (impulso vital). Por fim, mostraremos como uma nova concepção de causalidade dinâmica (em oposição à causalidade estática) é possível na concepção bergsoniana de evolução.

\section{1}

\section{Causalidade e duração:}

No Ensaio sobre os dados imediatos da consciência (1896), vimos a tendência do senso comum em confundir tempo e espaço como uma maneira de nossa consciência ser prática e agir no mundo. Em decorrência disso, todo o nosso conhecimento pensa em termos espaciais, o que leva à crença de algumas ilusões. Cabe à filosofia, ao separar os mistos ${ }^{78}$, como nos termos de Gilles Deleuze, operar essa distinção fundamental entre tempo e espaço. Enquanto sujeitos dotados de percepção, tendemos a espacializar o tempo na medida em que dividimos o tempo infinitamente em fragmentos, pois o espaço é uma multiplicidade quantitativa. $\mathrm{O}$ mesmo não pode ser feito quando pensamos o tempo independentemente do espaço, isto é, como duração, pois não se trata de uma medida quantitativa, mas de uma multiplicidade qualitativa. Para demonstrar essa tese, Bergson menciona a questão das sensações, exemplo que retomaremos para mostrar como surge o problema da causalidade.

Ao sermos afetados por um estímulo de calor, podemos saber a medida quantitativa desse estímulo e podemos estabelecer correlações em termos de grandezas (uma temperatura de 30 graus Celsius é inferior a uma temperatura de

\footnotetext{
78 "Trata-se sempre, segundo Bergson, de dividir um misto segundo suas articulações naturais, isto é, em elementos que diferem por natureza" (DELEUZE, 1999, p. 14).
} 
60 graus Celsius, e assim por diante). No entanto, se for preciso correlacionar essa medida quantitativa com nossas sensações, nem sempre é possível entrar em um acordo sobre a medida de tais sensações, pois cada consciência é individual e tem uma duração própria. Não é possível estabelecer uma concordância sobre grandezas de sensações, e essa é a principal crítica introduzida no Ensaio por meio dos exemplos dos experimentos psicofísicos de Fechner. A principal conclusão é a de que não há uma analogia entre estímulos espaciais e sensações, pois estas existem na duração. É isso que o autor chama de uma multiplicidade qualitativa: a característica intensiva de nossa consciência que explica que, com um mesmo estímulo, uns podem sentir prazer enquanto outros sentem dor.

Historicamente falando, essa distinção já estava presente em Nicolas Malebranche, filósofo francês cartesiano do século XVII. Em Diálogos sobre a metafísica e a religião ${ }^{79}$, no terceiro diálogo entre Theodoro e Ariste, surge o problema da causalidade. Essa noção é questionada pelo fato de a percepção de um mesmo estímulo poder resultar em prazer ou dor, de acordo com sua intensidade. A conclusão é que a sensação sentida por um indivíduo não é proporcional à grandeza quantitativa do estímulo ${ }^{80}$. Em uma análise bergsoniana,

\footnotetext{
${ }^{79}$ MALEBRANCHE, Nicolas. Entretiens sur la métaphysique et la religion: Suivi d'extraits des entretiens sur la mort. Paris: Librairie Armand Colin, 1922.

${ }^{80}$ Teodoro : - Houve muito espírito; pois lhe falta nesse lado. Mas o princípio é obscuro; ele se apoia sobre ideias claras. Tome cuidado. Você acredita conhecer o que você apenas sente; e toma por princípio um preconceito do qual reconheceu a falsidade anteriormente. Mas para fazer sentir a falsidade de sua prova, sofra para que eu lhe faça uma pequena experiência. Me dê a sua mão: não lhe farei grande mal. Presentemente que eu lhe esfregue a palma da mão com a ponta de minha manga, não se sente nada?
}

Ariste: Sinto um pouco de calor, ou uma espécie de cócegas bastante agradável.

Teodoro: E agora?

Ariste: - Ah! Teodoro! Você me machuca. Me esfrega muito fortemente. Sinto uma dor que me incomoda.

Teodoro: - Você se engana, Ariste. Deixe-me fazer. Você sente um prazer duas ou três vezes maior do que sentia há pouco. Vou provar-lhe pelo mesmo raciocínio. Tome cuidado: a fricção que faço em sua mão é a causa do que sentes. Ora, a causa inteira é a sua metade como 2 a 1, e os efeitos respondem exatamente à ação de suas causas. Então o efeito da causa inteira ou da ação inteira da causa é o dobro do efeito de sua metade. Então, ao friccionar uma vez mais forte ou mais rápido, esse movimento redobrado deve produzir uma vez mais prazer. Então não lhe fiz do, se é o que pretende que a dor seja para o prazer como 2 a 1 .

No original : «Théodore : - Il y a beaucoup d'esprit ; car vous ne manquez pas de ce côté-là. Mais le principe en est obscur; il n'est point appuyé sur des idées claires. Prenez-y garde. Vous croyez connaître ce que vous ne faites que sentir ; et vous prenez pour principe un préjugé dont vous aviez reconnu la fausseté auparavant. Mais pour vous faire sentir la fausseté de votre preuve, souffrez que je fasse sur vous une petite expérience. Donnez-moi votre main : je ne vous ferai pas grand mal. Présentément que je vous frotte le creux de la main avec le bout de ma manche, ne sentezvous rien?

Ariste : - Je sens un peu de chaleur, ou une espèce de chatouillement assez agréable.

Théodore : - Et maintenant? 
isso se deve principalmente ao fato de que o estímulo existe no espaço e pode, portanto ser mensurado quantitativamente, e o mesmo não é verdadeiro para a sensação, supostamente correspondente a esse estímulo.

Qual seria então a relação entre esse exemplo já explorado por Malebranche e a questão da causalidade no âmbito da obra de Bergson? Se é possível demonstrar, a partir do exemplo do calor, que não há uma analogia quantitativa entre estímulo e sensação, visto que são registros diferentes, então torna-se problemático considerar que um estímulo é de fato a causa direta de uma sensação. Se a sensação é de outra natureza do que sua causa geradora, como é possível considerar que há uma relação direta entre a causa e seu efeito? Essa confusão sobre uma analogia possível entre causa e efeito de uma sensação resulta do erro comum de se pensar que é possível medir os efeitos conscientes de uma analogia desde a sua causa, o que se mostra impossível, uma vez que nem todo estímulo externo, uma vez dobrado, provoca uma sensação duas vezes maior.

\section{2}

\section{A ilusão da causalidade no contexto da evolução:}

É em $A$ evolução criadora que Bergson analisa em mais detalhes a questão da causalidade, e é nessa análise que nos basearemos para propor uma compreensão da questão do porvir. Em um primeiro momento, sugerimos pensar a questão da evolução em uma perspectiva biológica e, em seguida, na perspectiva filosófica para, então, propor como essas duas disciplinas são complementares para compreender o problema da ilusão da causalidade.

Ariste : - Ah! Théodore! vous me faites mal. Vous me frottez trop rudement. Je sens une douleur qui m'incomode.

Théodore : - Vous vous trompez, Ariste. Laissez-moi faire. Vous sentez un plaisir deux ou trois fois plus grand que vous sentiez tout à l'heure. Je m'en vais vous le prouver par votre même raisonnement. Prenez garde : le frottement que je fais dans votre main est la cause de ce que vous y sentez. Or la cause entière est à sa moitié comme 2 à 1 , et les effets répondent exactement à l'action de leurs causes. Donc l'effet de la cause entière ou de l'action entière de la cause est double de l'effet de sa moitié. Donc, en frottant une fois plus fort ou plus vite, ce mouvement redoublé doit produire une fois plus de plaisir. Donc je ne vous ai point fait de douleur, si ce n'est que vous prétendiez que la douleur soit au plaisir comme 2 à 1 . 


\subsection{1}

\section{Perspectivas biológicas da evolução}

A perspectiva biológica da evolução pode ser exposta da seguinte maneira: desde o início da vida, o que permitiu seu surgimento e uma existência contínua de formas vivas no mundo (resultando num ponto culminante de variabilidade máxima de espécies) foram mecanismos de repetição de padrões de sucesso em cada uma das espécies. Junto a isto, a seleção natural, compreendida como o processo para explicar a adaptação das espécies, também tem papel fundamental na perpetuação das mesmas. A seleção natural tem trabalhado no sentido de garantir a sobrevivência e perpetuação dos indivíduos mais aptos. Mas isso só foi possível pela preexistência de uma matéria-prima inerente às espécies sobre a qual ela poderia ter agido, isto é, um certo número de indivíduos existentes sobre os quais a seleção poderia fazer uma triagem daqueles que são mais aptos ao seu ambiente.

A lei darwiniana de adaptação das espécies é o exemplo mais relevante dessa ideia. As espécies que sobrevivem são as espécies melhor adaptadas e, devido a essa adaptação, são capazes de transmitir as características às futuras gerações que, por meio de leis da genética, são mais prováveis de herdarem tais características. Nessa perspectiva, podemos destacar regras claras de causalidade: o fato de um indivíduo ser detentor de determinadas características, pelas leis das genéticas, permite que esse indivíduo passe tais características adiante para a próxima geração. Nesse sentido, a causa seria um primeiro indivíduo que, por meio de leis de hereditariedade, passa adiante determinadas características, sendo o efeito um indivíduo da futura geração herdá-las. Na concepção de Bergson isso é uma evidência concreta, mas um dos problemas é o fato de que, nesse caso, esse tipo de explicação ora adere às doutrinas mecanicistas, ora às doutrinas finalistas sobre a vida. Esse tipo de explicação também não abrange as exceções às regras, que levam na genética o nome de mutações. 


\subsubsection{1 \\ Mecanicismo e finalismo}

A concepção mecanicista da vida é aquela que considera um sistema artificial, isto é, um sistema geral das ciências que se explica a partir de leis causais mecânicas de movimento. Para que a ciência possa prever determinados eventos, é preciso que seja criado um sistema artificial de objetos sendo analisados, o que exclui automaticamente uma grande parte do que é vivo, isto é, aquilo que existe no contexto geral do universo. Isso se deve ao fato de os sistemas científicos não considerarem o tempo como duração, mas apenas em termos de espaço. Em outras palavras, os sistemas científicos são artificiais pois consideram um tempo presente e instantâneo, e não a duração na qual passado e presente são intrinsecamente conectados com o futuro.

Em suma, o mundo sobre o qual o matemático opera é um mundo que morre e renasce a cada instante, o mesmo ao qual pensava Descartes quando ele falava sobre criação contínua. Mas, no tempo assim concebido, como se representar uma evolução, isto é, o traço característico da vida? A evolução, ela, implica uma continuação real do passado pelo presente, uma duração que é um traço de união. Em outros termos, o conhecimento de um ser vivo ou de um sistema natural é um conhecimento que diz respeito ao intervalo mesmo de duração, enquanto o conhecimento de um sistema artificial ou matemático diz respeito apenas à extremidade $^{81}$ (BERGSON, 2013c, p. 22, tradução nossa).

É a própria tarefa da ciência a de prever, se concentrar sobre o estático até mesmo na perspectiva do vivente, para que seja possível deduzir leis da experiência e generalizá-las em fórmulas, em suma, matematizar a experiência. Embora isso seja útil e obtenha resultados em um sentido pragmático, se nos colocarmos em uma perspectiva filosófica, é nossa tarefa conceber a passagem do tempo no qual haja imprevisibilidade presente nas formas de vida e uma realidade cuja principal característica seja a mudança contínua. Na perspectiva de Bergson, as explicações mecanicistas podem então ser resumidas da seguinte maneira:

\footnotetext{
${ }^{81}$ Bref, le monde sur lequel le mathématicien opère est un monde qui meurt et renaît à chaque instant, celui-là même auquel pensait Descartes quand il parlait de création continuée. Mais, dans le temps ainsi conçu, comment se représenter une évolution, c'est-à-dire le trait caractéristique de la vie ? L'évolution, elle, implique une continuation réelle du passé par le présent, une durée qui est un trait d'union. En d'autres termes, la connaissance d'un être vivant ou système naturel est une connaissance qui porte sur l'intervalle même de durée, tandis que la connaissance d'un système artificiel ou mathématique ne porte que sur l'extrémité.
} 
As explicações mecânicas, dizíamos nós, são válidas para os sistemas que nosso pensamento destaca artificialmente do todo. Mas do todo ele mesmo e dos sistemas que, nesse todo, se constituem naturalmente à sua imagem, não podemos admitir a priori que eles sejam explicáveis mecanicamente, pois então o tempo seria inútil. A essência das explicações mecânicas é, com efeito, de considerar o porvir e o passado como calculáveis em função do presente, e de pretender assim que tudo está dado ${ }^{82}$ (BERGSON, 2013c, p. 37, tradução nossa).

Nesse caso, a causalidade (quando concebida como a relação entre uma causa A e o seu efeito direto, B) é perfeitamente plausível, pois um evento futuro pode ser precisamente calculado e previsto em função de uma causa presente, e assim por diante. Isso se deve ao fato de explicações mecânicas conceberem "passado e futuro como calculáveis em função do presente".

Consideremos agora o finalismo como outra explicação possível para a evolução. As doutrinas finalistas são explicações teleológicas que implicam que tudo o que ocorre no mundo tende a um fim específico, isto é, a uma causa final que determina todo o curso dos eventos. Dependendo do tipo de doutrina finalista, essa causa final pode variar. No caso de Bergson, o finalismo é generalizado sob uma de suas formas mais radicais, a saber, como o finalismo leibniziano. A crítica de Bergson a tais doutrinas é apresentada da seguinte forma:

Mas o finalismo radical nos parece tão inaceitável, e pelo mesmo motivo. A doutrina da finalidade, tal qual a encontramos em Leibniz, por exemplo, implica que todas as coisas e todos os seres não fazem nada além de realizar um programa uma vez traçado. Mas se não há nada de imprevisto, nenhuma invenção e nem criação no universo, o tempo se tornaria novamente inútil. Como na hipótese mecânica, supomos novamente aqui que tudo está dado ${ }^{83}$ (BERGSON, 2013c, p. 39, tradução nossa).

Tanto as explicações mecanicistas como as finalistas são problemáticas pelo mesmo motivo: elas falham em compreender a natureza da duração,

\footnotetext{
${ }^{82}$ Les explications mécanistiques, disions-nous, sont valables pour les systèmes que notre pensée détache artificiellement du tout. Mais du tout lui-même et des systèmes qui, dans ce tout, se constituent naturellement à son image, on ne peut admettre a priori qu'ils soient explicables mécaniquement, car alors le temps serait inutile. L'essence des explications mécanistiques est en effet de considérer l'avenir et le passé comme calculables en fonction du présent, et de prétendre ainsi que tout est donné. Dans cette hypothèse, passé, présent et avenir seraient visibles d'un seul coup pour une intelligence surhumaine, capable d'effectuer le calcul.

${ }^{83}$ Mais le finalisme radical nous parait tout aussi inacceptable, et pour la même raison. La doctrine de la finalité, telle que nous la trouvons chez Leibniz, par exemple, implique que les choses et les êtres ne font que réaliser un programme une fois tracé. Mais, s'il n'y a rien d'imprévu, point d'invention ni de création dans l'univers, le temps devient encore inutile. Comme dans l'hypothèse mécanistique on suppose encore ici que tout est donné.
} 
concebendo o tempo em função do espaço - o mesmo problema inicial apresentado no Ensaio. A consequência direta disso, em ambos os casos, é uma logica de que "tudo está dado", resultando em uma concepção completamente previsível do mundo.

O princípio que norteia essa lógica certamente é o de causalidade, de acordo como qual um evento B resulta de uma causa A. De alguma forma, esse efeito já estava contido em sua causa A e pode, portanto, ser previsto. Se suprimíssemos esse princípio, o resultado seria a aleatoriedade completa e a desordem que tenderia a um mundo caótico. Nesse sentido, nossa hipótese é a de que Bergson não nega totalmente o fato de que há uma certa ordem, embora também esteja condenando a maneira por meio da qual a nossa habilidade intelectual classifica essa ordem de modo a nos guiar para a aceitação do pensamento de que "tudo está dado".

A existência de leis causais no mundo natural não é excluída, embora a nossa hipótese é a de que seja preciso repensar a causalidade em termos diferentes, e isso só é possível por meio de uma tese intermediária entre a de que "tudo está dado" e o caos completo.

O princípio de causalidade deve ser negado se for concebido como estático. Para que ele seja possível no contexto da obra, deve ser pensado como uma causalidade dinâmica que permite a novidade, a espontaneidade e a imprevisibilidade: características presentes em tudo o que é dotado de vida. Há evidências textuais para o fato de que, ao abraçar ao argumento da necessidade de leis causais, Bergson tende a recuperar parte do finalismo. "A tese que exporemos nesse livro participará então necessariamente do finalismo em uma certa medida. É por esse motivo importante indicar com precisão o que nós vamos considerar, e o que nós pretendemos deixar" ${ }^{84}$ (BERGSON, 2013c, p. 40, tradução nossa). Entre finalismo e mecanicismo, a doutrina inaceitável é o mecanicismo pois não permite nada fora da lógica de que "tudo está dado".

Parte da tarefa de $A$ evolução criadora é então a de compreender como o finalismo pode ser aproveitado, já que há evidências para uma ordem da natureza, embora essa mesma ordem contenha nela própria o imprevisível sem tender ao

\footnotetext{
${ }^{84} \mathrm{La}$ thèse que nous exposerons dans ce livre participera donc nécessairement du finalisme dans une certaine mesure. C'est pourquoi il importe d'indiquer avec précision ce que nous allons en prendre, et ce que nous entendons en laisser.
} 
caos completo. A questão proposta por Bergson é então a de como é possível participar no finalismo ${ }^{85}$ e questionar o fato de que há uma causalidade previsível no mundo?

A nossa hipótese interpretativa sobre essa recuperação do finalismo se dá em dois momentos: o primeiro, no que diz respeito à ideia de uma causa final geral, e o segundo, no que diz respeito à causalidade na evolução. Nesse sentido, o finalismo se refere à tese de que tudo o que ocorre no mundo tende a uma causa final e, portanto, todas as ações já são pré-determinadas visando cumprir essa causa final.

Se o finalismo deve seguir algum tipo de causa geral, nos parece que, em Bergson, essa não é uma causa final para a qual todo o funcionamento do mundo se direciona, mas sim uma causa original, inicial, a partir da qual as tendências se desenvolvem em inúmeras linhas diferentes. O nome dado a essa causa é élan vital: seria o equivalente a uma causa inicial - da ordem de uma força vital -, que se divide em tendências diversas, entre cada espécie e cada direção que toma a vida, encontrando os obstáculos impostos pela materialidade. Nesse sentido, o erro do finalismo seria supor uma harmonia final no mundo, quando, na realidade, o que há é apenas uma força inicial que se desenvolve em tendências imprevisíveis. De certa forma, a maneira que Bergson parece encontrar para não rejeitar inteiramente o finalismo é a de recuperar a ideia de uma causa, mas reposicioná-la como tendência inicial, e não como causa final em direção à qual o mundo tende.

Considerando agora o segundo aspecto, isto é, o desencadeamento de causas no contexto da evolução, uma vez que se admite a presença de um élan original criador que se desenvolve em tendências e linhas evolutivas diferentes, o problema se divide da seguinte maneira: ao aceitarmos que há uma causalidade, aceitamos a previsibilidade da evolução, mas isto já foi demonstrado como falso. A ordem da natureza é inegável, pois se não existisse, o resultado seria o caos total.

\footnotetext{
${ }^{85}$ É importante notar que o finalismo é generalizado, sendo a sua vertente mais radical o exemplo do sistema leibniziano. Bergson não especifica o tipo de finalismo que gostaria de salvar, apenas mostra que o finalismo radical de Leibniz não pode explicar o encadeamento de causas na natureza, pois, justamente, não pode admitir o imprevisível e o absolutamente novo, visto que tudo segue uma doutrina pré-traçada a ser respeitada. No entanto, Bergson insiste no fato de que deve aderir a um tipo particular de finalismo para dar conta das explicações acerca da natureza.
} 
Por outro lado, uma tendência que se desenvolve a partir do élan vital admite novidade e variabilidade máxima: tudo se originou de um mesmo início que se transformou em diferentes espécies e indivíduos. No primeiro caso, o de considerar a causalidade e então o mundo como previsível, a causalidade é uma causalidade que chamaremos de "estática": os efeitos já estão previamente contidos em suas causas e não admitem parcela de novidade com relação à sua causa. Ora, a causalidade parece encontrar sentido em $A$ evolução criadora na medida em que ela é pensada como "dinâmica", isto é, quando o efeito não apenas contém tudo aquilo que a sua causa já continha, mas uma parcela de indeterminação, de novidade, de imprevisibilidade. Em nossa hipótese, essa seria a única maneira de "recuperar" um finalismo: admitindo-se uma causa inicial, o élan vital, e admitindo-se uma causalidade dinâmica que permite um caráter de indeterminação nos efeitos com relação às suas respectivas causas. É nesse sentido que podemos aceitar um finalismo sem que tudo já esteja dado, embora esse finalismo não esteja mais no final, mas como causa inicial que se desenvolve sem direção final.

Um dos exemplos que podemos apresentar para demonstrar essa tese toma como base a noção de “obstáculos". O sucesso de uma espécie é o critério incontestável de superioridade no contexto da evolução. Para que uma espécie sobreviva, foi preciso que dois tipos de força entrassem em contato: por um lado, uma força destrutiva e de degradação - a matéria -, por outro, uma força criadora e vital, o élan vital exemplificado pela divergência de tendências. A matéria é, para Bergson, o que impõe obstáculos ao vivente:

Não é contestável, por exemplo, que o sucesso seja o critério mais geral da superioridade, os dois termos sendo, até certo ponto, sinônimos um do outro. Por sucesso, é preciso compreender, quando se trata do ser vivo, uma aptidão a se desenvolver nos meios mais diversos, pela maior variedade de obstáculos, de maneira a cobrir a maior extensão de terra. ${ }^{86}$ (BERGSON, 2013c, p. 134, tradução nossa)

Quando um obstáculo se impõe às espécies, como, por exemplo, a matéria, as diversas espécies têm as mais variadas maneiras de ultrapassar esse obstáculo.

\footnotetext{
${ }^{86}$ Il n'est pas contestable, par exemple, que le succès soit le critérium le plus général de la supériorité, les deux termes étant, jusqu'à un certain point, synonymes l'un de l'autre. Par succès il faut entendre, quand il s'agit de l'être vivant, une aptitude à se développer dans les milieux les plus divers, à travers la plus grande variété possible d'obstacles, de manière à couvrir la plus vaste étendue possible de terre.
} 
Elas o fazem por meio de comportamentos diferentes, mesmo sua origem sendo o mesmo élan vital, mesmo tendo sido de certa forma geneticamente programadas e previsivelmente calculadas. O élan vital não se encontra em um início cronológico da vida, mas a perpassa em todos os seus aspectos, se desenvolvendo em tendências diversas.

Presente em cada tendência, o élan é utilizado por cada espécie de acordo com seu interesse, e eis o que chamamos de "adaptação". Não se trata de uma força intangível fora da natureza que a causa inicialmente, mas sim uma força presente em cada tendência e apropriada por cada espécie em sua adaptação. Isso não só indica a imprevisibilidade das formas orgânicas, mas também o caráter criador desse élan, que, mesmo sendo único no início, por meio das tendências que desenvolve é capaz de se manifestar de forma criadora. O que é vivo, nesse caso, é sinônimo de criação e a realidade se define então para Bergson como "um jorro ininterrupto de novidade ${ }^{87, "}$ (BERGSON, 2013c, p. 47, tradução nossa).

\section{3 \\ A realidade do porvir}

Se a causalidade não pode ser concebida em seus termos clássicos, isto é, como estática, como então é possível estabelecer uma nova possibilidade para nossa crença nesse princípio não somente no contexto de uma filosofia da duração, mas também respeitando a hipótese de que há um conhecimento do porvir? Primeiramente, em oposição a uma causalidade estática na qual todo efeito já se encontra previamente contido em sua causa, propomos a noção de uma causalidade dinâmica: ou seja, um tipo de relação entre causa e efeito que permita que haja mais, e não menos, em um efeito do que em sua causa. Em outros termos, uma causa é a origem direta de um efeito, mas o efeito que resulta dessa causa, além de estar contido nela previamente, permite algo além da causa: uma parcela de novidade ou de imprevisibilidade.

\footnotetext{
${ }^{87}$ la réalité nous apparaît alors comme
} 
Essa concepção é compatível com a ideia de resgatar um tipo de finalismo após a rejeição das teorias mecanicistas ${ }^{88}$. Se considerarmos esses dois aspectos, a recuperação de um finalismo “às avessas” e uma concepção dinâmica de causalidade, podemos então sugerir como é possível um conhecimento do porvir. Como então seria possível resgatar o finalismo, ou ao menos aproveitar a sua origem, sem se render a um sistema em que "tudo está dado"? Nossa hipótese é a de que o conceito de élan vital pode ajudar a solucionar esse problema. Em suma, se Bergson propõe uma força vital na origem da vida, isso equivaleria a um finalismo "às avessas", em que o encadeamento da vida ocorre não visando uma causa final pré-estabelecida, mas decorrente de uma causa inicial. No entanto, essa causa inicial não se desenvolve rígida e determinadamente, mas por meio do que Bergson chama de "tendências". O élan vital perpassa então cada linha de evolução divergente e é apropriado pelas espécies de acordo com um interesse de sobrevivência que é chamado de "adaptação".

O conhecimento da realidade do porvir se dá na medida em que saímos da posição da ciência e da inteligência, isto é, a de destacar sistemas artificialmente recortados e na medida em que nos inserimos, enquanto viventes, no Todo do universo, por sua vez também constituído por viventes. Nesse caso, a inteligência, faculdade por excelência do ser humano, tem como característica proporcionar o conhecimento do vivente como estático, congelando-o, enrijecendo formas mutáveis para que possa operar um corte de conhecimento instantâneo sobre ela, que é então generalizado em leis. A inteligência se define como "a faculdade que permite trazer um ponto do espaço ao outro, um objeto material a outro objeto material; ela se aplica a todas as coisas, mas permanecendo fora delas $(\ldots)^{89,}$ (BERGSON, 2013c, p. 176, tradução nossa).

Nesse sentido, a única alternativa possível para o conhecimento do porvir (e esse sentido não permite que conhecimento seja sinônimo de previsão) seria por meio do que Bergson chama de intuição. A intuição é justamente a faculdade que nos permite pensar em duração (penser en durée), isto é, a faculdade que nos posiciona em uma duração que coincide com aquela do objeto, em uma

\footnotetext{
${ }^{88}$ Doutrina determinista segundo a qual todos os fenômenos se explicam pela causalidade mecânica.

${ }^{89}$ Plus précisément, l'intelligence est, avant tout, la faculté de rapporter un point de l'espace à un autre point de l'espace, un objet matériel à un objet matériel ; elle s'applique à toutes choses, mais en restant en dehors d'elles (...).
} 
possibilidade de coexistência com aquilo que se conhece. Diferente da inteligência, que ora antecede, ora já está obsoleta com relação ao conhecimento do que muda incessantemente, a intuição permite a coexistência, ou seja, uma concomitância entre minha duração e a duração do universo.

Não se trata de tangenciar o que se deseja conhecer, mas colocar-se no próprio interior do objeto a ser conhecido, na relação mais próxima de um sujeito, tornar-se por um instante fugaz esse próprio objeto do conhecimento. A inteligência pode ser considerada como suficiente no que diz respeito ao conhecimento do estático e do inorgânico, mas o mesmo não pode ser dito sobre o conhecimento das leis da vida e do orgânico. Trata-se de uma organização de tensões, de criação orgânica, incalculável pela ciência matemática, e outra de destruição e desintegração contínua, característica da materialidade. Essas forças não são excludentes, mas a vida se explica pela preponderância da força das tendências sobre a matéria bruta, a qual impõe obstáculos a essa força vital.

É assim para a fragmentação da vida em indivíduos e em espécies. Ela se deve, acreditamos, a duas séries de causas: a resistência que a vida experimenta por parte da matéria bruta, e a força explosiva - devido a um equilíbrio instável de tendências - que a vida carrega nela ${ }^{90}$ (BERGSON, 2013c, p. 99).

Na medida em que concebemos o real como essas duas tensões: matéria e vida intermediadas pela noção de tendência, podemos admitir que, na medida em que vida é sinônimo de criação, espontaneidade, imprevisibilidade, a realidade do porvir só pode ser apreendida por meio de uma compreensão da vida, que, por sua vez, é definida como duração apenas. Isso não significa que seja possível ter previsões exatas, mas sim que, por meio de um trabalho da intuição, a imprevisibilidade possa se dar em uma coincidência com o conhecimento da duração por parte do sujeito. ]

Isso significa, em outros termos, que o sujeito que conhece por meio da inteligência não possui acesso às formas do tempo puro, apenas ao que uma concepção espacializada do tempo lhe proporciona: recortes artificiais no todo, imobilidades e um conhecimento do estático.

\footnotetext{
${ }^{90}$ Ainsi pour la fragmentation de la vie en individus et en espèces. Elle tient, croyons-nous, à deux séries de causes: la résistance que la vie éprouve de la part de la matière brute, et la force explosive - due à un équilibre instable de tendances - que la vie porte en elle.
} 
No entanto, por meio de intuições simples (as quais requerem um árduo trabalho metafísico - são simples por serem imediatas, e não por serem de assimilação simples), isto é, por meio de um esforço da intuição, é possível alcançar o conhecimento do tempo puro, ou seja, da duração. É nesse tipo de conhecimento que podemos ter acesso ao vivente, que é, por sua vez, o movente. É ao pensar em duração (penser en durée) que é possível coincidir com a passagem do presente ao porvir e compreender a imprevisibilidade e espontaneidade características do mundo. A possibilidade de haver novidade e criação no universo está intimamente ligada, portanto, à possibilidade de haver liberdade. Nesse sentido, liberdade e criação são sinônimos, e, por meio da crítica à nossa crença na causalidade mecânica, é possível contemplar a existência da liberdade no contexto da evolução.

\section{4}

\section{Causalidade e liberdade}

No Ensaio sobre os dados imediatos da consciência, o problema da causalidade surge na crítica a uma suposta analogia, determinada pelo estudo da psicofísica, entre estímulos quantificáveis causando sensações igualmente quantificadas, quando, na realidade, trata-se de uma diferença qualitativa entre sensações, e não quantitativa. A partir desse estudo, Bergson sugere a noção de um momento de indeterminação no sujeito e no ser humano, esse intervalo de indeterminação é, na hipótese de Bergson, o maior entre todas as espécies. Esse pensamento vem de uma herança do pensamento de Félix Ravaisson, conforme discutimos no segundo capítulo: quanto maior o ser for evoluído na escala das espécies, maior será o seu intervalo de indeterminação.

No Ensaio, o ato livre vem justamente dessa capacidade de indeterminação: o homem é, portanto, o único animal que pode se permitir fazer movimentos desnecessários. Em A Evolução criadora, a partir da noção de tendência é que surge a possibilidade de liberdade. Por meio da ideia de um élan vital, presente como causa original que continua perpassando as espécies ao longo da vida (e não como causa final), a noção de tendência permite que nem todo efeito esteja contido em sua causa. 
No primeiro momento da investigação, conforme apresentada no Ensaio sobre os dados imediatos da consciência, a noção de duração é associada à consciência apenas. Isso significa que a crítica à noção de causalidade resulta na possibilidade de pensar atos livres referentes a um indivíduo dotado de consciência. Em A Evolução criadora, uma das principais afirmativas é a de que a duração não é característica apenas da consciência, mas do universo: "O universo dura. Quanto mais nos aprofundarmos na natureza do tempo, mais compreenderemos que duração significa invenção, criação de formas, elaboração contínua do absolutamente novo"91. (BERGSON, 2013b, p. 11, tradução nossa).

Sendo assim, passamos de uma possibilidade de liberdade individual para a possibilidade de uma liberdade presente no universo e em toda a evolução da vida. Essa passagem implica a existência do novo, de uma criação: o que é exemplificado pela biologia em que a adaptação não é apenas resultado de gerações sucessivas que passam características genéticas, mas sim de movimentos de superações de obstáculos visando a sobrevivência e de uma apropriação do élan vital. $\mathrm{Na}$ medida em que pensamos em termos de uma analogia entre a causalidade mecânica no mundo material aplicável ao campo da consciência, continuamos voltando à tese determinista e torna-se impossível admitir a existência de atos livres.

Por um lado, vida e criação são inseparáveis, por outro, relações de causalidade mecânica implicam uma previsibilidade do efeito a partir de sua causa, o que não permite que haja novidade alguma na realização de um efeito. Provada a impossibilidade dessa tese na relação entre antecedentes psíquicos e nossas ações, ela se aplica ao tema da evolução. Encontramos novamente aqui a impossibilidade de se estabelecer uma analogia entre os sistemas artificias recortados pela ciência e a totalidade da evolução e da vida:

A única questão é saber se os sistemas naturais que chamamos de seres vivos deve ser assimilados a sistemas artificiais que a ciência recorta na matéria bruta, ou se, por outro lado, eles não deveriam ser comparados ao sistema natural que é o todo do universo. Que a vida seja uma espécie de mecanismo, posso aceitar. Mas seria esse o mecanismo de partes artificialmente isoláveis no todo do universo ou aquele no todo real? (...) $\mathrm{Na}$ realidade, a vida não é feita de

\footnotetext{
${ }^{91}$ L'univers dure. Plus nous approfondirons la nature du temps, plus nous comprendrons que durée signifie invention, création de formes, élaboration continue de l'absolument nouveau (BERGSON, 2013b, p. 11).
} 
elementos físico-químicos assim como uma curva não é composta por linhas $\operatorname{retas}^{92}$ (BERGSON, 2013b, p. 30, tradução nossa).

Ao criticar a causalidade como uma "ilusão", Bergson não pretende eliminá-la totalmente de sua argumentação, mas defende que uma causalidade mecânica seja insuficiente na explicação do porvir como sinônimo de novidade. O que propomos então é pensar em uma causalidade "dinâmica", que poderia ser compreendida no contexto da consciência no Ensaio e da evolução da vida em $A$ Evolução criadora. A característica que difere no humano é então a de que a liberdade não está associada à sobrevivência apenas, mas à vida. A liberdade passa então de um nível individual para um nível absoluto, passa de uma condição de sobrevivência para uma condição de vida, e é, nesse sentido, inseparável de um caráter criador.

${ }^{92}$ L'unique question est de savoir si les systèmes naturels que nous appelons des êtres vivants doivent être assimilés aux systèmes artificiels que la science découpe dans la matière brute, ou s'ils ne devraient pas plutôt être comparés à ce système naturel qu'est le tout de l'univers. Que la vie soit une espèce de mécanisme, je le veux bien. Mais est-ce le mécanisme des parties artificiellement isolables dans le tout de l'univers ou celui du tout réel ? (...) En réalité, la vie n'est pas plus faite d'éléments physico-chimiques qu'une courbe n'est composée de lignes droites (BERGSON, 2013b, p. 30). 


\section{5 \\ Considerações finais}

O conhecimento como metafísica do movente depende essencialmente de refundar a metafísica clássica à luz de uma compreensão do tempo independente do espaço. Isso significa compreender as ilusões que um conhecimento baseado no espaço proporciona a um sujeito dotado de consciência, isto é, um sujeito que dura. Bergson parece apresentar o problema da fundamentação da metafísica em dois níveis. O primeiro, é um nível geral mais crítico de questões postuladas pela metafísica clássica, como, por exemplo, o falso problema entre ordem e desordem, entre o porquê de haver o ser e não o nada. Em um segundo nível, partindo de explicações científicas de seu tempo (como o problema da simultaneidade e de uma localização física da lembrança, assim como a repercussão da teoria da evolução), Bergson mostra em exemplos específicos como esses problemas são, se seguirmos as verdadeiras articulações do real e afastarmos as ilusões que nos velam o acesso ao movente. O problema do conhecimento do real como mudança contínua encontra-se presente como núcleo dessas três ilusões: simultaneidade, localização física da lembrança e causalidade: por um lado, é preciso compreender a dificuldade central que diz respeito em se conhecer a mudança nela mesma; por outro, são exemplos que lançam luz sobre casos específicos em que o tema central é a incapacidade de se pensar a mudança como absoluta, ou seja, o real como movente.

A forte presença da ciência nas três obras analisadas - O Ensaio sobre os dados imediatos da consciência (1888), Matéria e memória (1896) e A evolução criadora (1907) - aponta para um movimento geral do bergsonismo, isto é, o de tornar a filosofia "precisa", conforme indicado nas primeiras frases de $O$ pensamento e o movente ${ }^{93}$. Não se trata de aplicar os mesmos métodos da ciência à filosofia, tampouco de tentar comparar uma disciplina à outra. É preciso compreender que os problemas apresentados pela ciência (a física, a psicofísica, a biologia, por exemplo) são considerados na perspectiva do espaço, e não do tempo. Cabe à filosofia, mais especificamente à metafísica, refundar esses

\footnotetext{
93 "O que mais faltou à filosofia foi a precisão. Os sistemas filosóficos não são esculpidos à medida da realidade onde vivemos." (BERGSON, 2013b, p. 1, tradução nossa). No original: "Ce qui a le plus manqué à la philosophie, c'est la précision. Les systèmes philosophiques ne sont pas taillés à la mesure de la réalité."
} 
problemas com base no tempo, independentemente do espaço. É assim que surge a ideia de que o conhecimento do tempo depende intrinsecamente de se fazer uma "metafísica do movente".

Em cada uma das ilusões analisadas - simultaneidade, localização física da lembrança e causalidade -, podemos notar que, ao formular o problema em termos espaciais ao invés de temporais, voltamos a pensar a mobilidade em termos de imobilidades, o passado em termos de um armazenamento do presente, as lembranças em função das sensações, e os efeitos como inteiramente contidos em suas causas. Quando acessamos o tempo puro, (isto é, a duração) por meio da superação de determinados falsos problemas, acessamos o real de acordo com suas articulações naturais, sem destaca-lo artificialmente do Todo. Dotados de inteligência, tendemos a olhar para o estático apenas, sendo assim preciso um esforço de outra ordem - a intuição, para que possamos pensar em duração e assim compreender o movimento, a mudança, a lembrança, a novidade e a espontaneidade.

Analisando o conhecimento da mudança através dessas três obras de Bergson, percebe-se um deslocamento do problema em três momentos. No Ensaio sobre os dados imediatos da consciência, há uma separação nítida entre o mundo da consciência, do sujeito, da duração e o espaço exterior. Essa separação abre lugar para uma posição crítica sobre um dualismo inicial entre consciência e mundo exterior, que parece, nesse momento, impossibilitar um conhecimento do real (por que ele é mudança contínua) por parte de um sujeito. Em Matéria e memória, vemos que há um deslocamento da duração para algo além do sujeito no momento presente, isto é, para a dimensão do passado puro. Nesse caso, torna-se importante o fato de que todas as experiências passadas do sujeito permanecem vivas em um passado puro independente do presente, e independente também de uma localização física no corpo - as evidências para essa tese encontram-se no estudo das afasias. Já em $A$ Evolução criadora, o sujeito não é mais concebido como independente do espaço pois a faculdade do conhecimento do real é diluída em duas tendências: a inteligência e a intuição.

A inteligência é aquela faculdade que nos situa no espaço, que enrijece o real e que o petrifica para que seja possível extrair um conhecimento sobre ele sempre obsoleto com relação ao seu verdadeiro devir. A intuição, por outro lado, é o que permite que, enquanto viventes, nos relacionemos com um real que é puro 
devir, na medida em que o conhecimento propiciado pela intuição resulta justamente em um recolocar-se na duração pura, gerando uma coincidência entre sujeito e objeto, em oposição a uma relação de exterioridade entre ambos.

A pertinência de uma refundação da metafísica em termos temporais está presente nessa nova concepção da mudança baseada na identificação das verdadeiras diferenças de natureza, e não de grau, entre elementos do conhecimento. Nesta dissertação, nosso principal objetivo foi evidenciar a maneira de aplicar a ideia de uma metafísica do movente a alguns problemas específicos criticados por Bergson. No entanto, cabe ressaltar que esse projeto bergsoniano de refundar a metafísica é ambicioso e depende também de refundar toda uma teoria do conhecimento baseada em conceitos. Esses conceitos, uma vez que dizem respeito ao real, que é movente, ora estão sempre obsoletos com relação ao objeto, ora se antecipam no caso de uma especulação. Embora o autor não negue a existência de conceitos e o fato de serem imprescindíveis na filosofia, a coincidência entre conceito e objeto nos parece problemática. O que apresentamos aqui, então, é um estudo para dirigir o pensamento em termos dessa metafísica do movente bergsoniana, refundando problemas específicos em termos temporais ao invés de espaciais: a saber, o problema da simultaneidade, o de uma localização física da lembrança, e o da causalidade. Sendo assim, abre-se uma nova possibilidade para uma teoria do conhecimento em Bergson, considerando que a precisão em filosofia advém do fato de se ter um conhecimento do tempo independente do espaço, ou seja, considerando o tempo como duração.

"Pensar em duração" (penser en durée) é, então, o modo de pensamento que possibilita o acesso à realidade de um tempo puro, e isso não se dá por meio da inteligência, mas da intuição, sendo esta definida da seguinte maneira:

Pensar intuitivamente é pensar em duração. A inteligência parte ordinariamente do imóvel, e reconstrói tão bem quanto mal o movimento com imobilidades justapostas. A intuição parte do movimento, o coloca, ou melhor, o percebe como a realidade ela mesma, e vê na imobilidade apenas um momento abstrato, instantâneo, tomado pelo nosso espírito sobre uma mobilidade ${ }^{94}$ (BERGSON, 2013b, p. 30, tradução nossa).

\footnotetext{
${ }^{94}$ Penser intuitivement est penser en durée. L'intelligence part ordinairement de l'immobile, e reconstruit tant bien que mal le mouvement avec des immobilités juxtaposées. L'intuition part du mouvement, le pose ou plutôt l'aperçoit comme la réalité même, et ne voit dans l'immobilité qu'un moment abstrait, instantané, pris par notre esprit sur une mobilité.
} 
Não se trata de ir além de problemas já colocados pela metafísica, mas sim de um recuo com relação a eles de modo a poder enxergar onde é preciso operar uma cisão, uma diferença fundamental entre os termos do problema, de modo que seja possível uni-los novamente sem incorrer no que Deleuze chama de "falsos problemas". Pensar em duração remete a um ato simples ao invés das complicações resultantes de uma percepção mista entre tempo e espaço: significa apenas retomar o real no que há de mais rudimentar, de mais natural - o fato de que ele é mudança contínua. Embora seja um ato simples, não é de fácil entendimento e execução. Muito pelo contrário, desfazer-se das concepções mistas do nosso entendimento revela-se, para Bergson, uma tarefa central à qual o autor dedica toda a sua obra. A intuição, embora caracterizada como ato simples, requer um esforço próprio do conhecimento metafísico. Pensar em duração tornase então, na obra de Bergson, a única possibilidade para uma concepção do movimento enquanto pura mudança, de um passado independente do presente, e do mundo como criação, espontaneidade e novidade. 


\section{6 \\ Referências bibliográficas}

AGAMBEN, Giorgio. Tempo e história: Crítica do instante e do contínuo. In:

AGAMBEN, Giorgio. Infância e história: Destruição da experiência e origem da história. Belo Horizonte: Editora UFMG, 2008. p. 109-128.

ALLIEZ, Eric. Deleuze Filosofia Virtual. São Paulo: Editora 34, 1996. Heloisa B. S. Rocha.

ALLIEZ, Eric. On Deleuze's Bergsonism. Discourse, Detroit, v. 3, n. 20, p.226246, out. 1998.

BENDA, Julien. Le bergsonisme ou une philosophie de la mobilité. 2. ed. Paris: Mercvure de France, 1974. Disponível em:

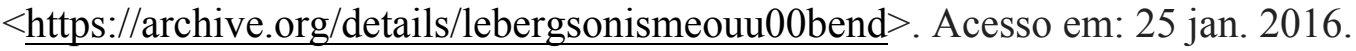

BERGSON, Henri. A evolução criadora. São Paulo: Martins Fontes, 2005. Tradução: Bento Prado Neto.

BERGSON, Henri. Durée et simultanéité: À propos de la théorie d'Einstein. 4. ed. Paris: Presses Universitaires de France, 2009. Édition critique dirigée par Frédéric Worms.

BERGSON, Henri. Écrits et paroles. Paris: Presses Universitaires de France, 1959. Textes rassemblés par R.M. Mossé-Bastide.

BERGSON, Henri. Écrits philosophiques. Paris: Presses Universitaires de France, 2011.

BERGSON, Henri. Ensaio sobre os dados imediatos da consciência. Lisboa: Edições 10, 1988. Tradução de: João da Silva Gama. Disponível em: $<$ https://www.academia.edu/4097207/BERGSON_Henri_Ensaio_sobre_os_dados imediatos da consciencia $>$. Acesso em: 25 jan. 2016.

BERGSON, Henri. Essai sur les données immédiates de la conscience. 10. ed. Paris: Presses Universitaires de France, 2013a. Édition critique dirigée par Frédéric Worms.

BERGSON, Henri. L'énergie spirituelle. Paris: Éditions Payot Et Rivages, 2012.

BERGSON, Henri. L'évolution créatrice. 12. ed. Paris: Presses Universitaires de France, 2013. Édition critique dirigée par Frédéric Worms.

BERGSON, Henri. La pensée et le mouvant. 17. ed. Paris: Presses Universitaires de France, $2013 b$. 
BERGSON, Henri. Le Rire: Essai sur la signification du comique. 3. ed. Paris: Presses Universitaires de France, 2011.

BERGSON, Henri. Les deux sources de la morale et de la religion. 11. ed. Paris: Presses Universitaires de France, 2013.

BERGSON, Henri. Matéria e memória. São Paulo: Martins Fontes, 1999. Tradução Paulo Neves.

BERGSON, Henri. Matière et mémoire. 8. ed. Paris: Presses Universitaires de France, 2008. Édition critique sous la direction de Frédéric Worms.

BERGSON, Henri. Introdução (Primeira Parte): Crescimento da verdade. Movimento retrógrado do verdadeiro.. In: BERGSON, Henri. O pensamento e o movente. São Paulo: Martins Fontes, 2006. p. 3-25. Tradução: Bento Prado Neto.

BIANCO, Giuseppe. Experience vs. concept? The role of Bergson in twentiethcentury French philosophy. The European Legacy, Warwick, v. 16, n. 7, p.855872, jan. 2011.

CAEYMAEX, Florence. Bergson, Sartre, Merleau-Ponty: les phénoménologies existentialistes et leur héritage bergsonien. In: FRANÇOIS, Arnaud. Annales bergsoniennes II: Bergson, Deleuze, la phénoménologie. Paris: Presses Universitaires de France, 2004. p. 409-424.

DELEUZE, Gilles. Bergsonismo. São Paulo: Editora 34, 1999. Tradução: Luiz B. L. Orlandi.

DELEUZE, Gilles. Différence et répétition. 11. ed. Paris: Presses Universitaires de France, 2003.

DELEUZE, Gilles. Image-mouvement: Cinéma 1. Lonrai: Les Éditions de Minuit, 2010.

DELEUZE, Gilles. Image-temps: Cinéma 2. Lonrai: Les Éditions de Minuit, 2010.

DELEUZE, Gilles. Le Bergsonisme. 3. ed. Paris: Presses Universitaires de France, 2004.

DELEUZE, Gilles. Bergson, 1859-1941. In: DELEUZE, Gilles. L'île déserte: Textes et entretiens 1953-1974. Paris: Les Éditions de Minuit, 2002. p. $28-42$.

DELEUZE, Gilles. La conception de la différence chez Bergson. In: DELEUZE, Gilles. L'île déserte: Textes et entretiens 1953-1974. Paris: Les Éditions de Minuit, 2002. p. 43-72. 
DURING, Élie. Coexistence and the flow of time. In: DURING, Élie. The Anatomy of Matter and Memory: Bergson and Contemporary Theories of Perception, Mind and Time. Tokyo: Shoshi Shinsui, 2016. p. 1-22.

DURING, Elie. Méthode ou système? Pour une métaphysique locale. Les Temps Modernes, Paris, v. 2015/1, n. 682, p.48-71, mar. 2015. Disponível em: $<$ https://www.academia.edu/12753268/DURING Méthode ou système Pour un e métaphysique locale 2015 _. Acesso em: 25 jan. 2016.

DURING, Élie; DURING, Élie. Présence et répétition: Bergson chez les phénoménologues. Critique, Paris, v. 11, n. 2003, p.848-864, out. 2014.

KANT, Emmanuel. Critique de la raison pure. 6. ed. Paris: Presses Universitaires de France, 1968. Traduction française avec notes par A. Tremesaygues et B. Pacaud.

FECHNER, Gustav Theodor. Elements of Psychophysics. New York: Holt, Rinehart And Winston Inc., 1966. Translated by: Helmut Adler.

FRANÇOIS, Arnaud. Histoire de la mémoire et histoire de la métaphysique. In: ARNAUD, François et al. Annales bergsoniennes II: Bergson, Deleuze, la phénoménologie. Paris: Presses Universitaires de France, 2004. p. 17-40.

HUSSON, Léon. L'intellectualisme de Bergson: Genèse et développement de la notion bergsonienne d'intuition. Paris: Presses Universitaires de France, 1947.

JAMES, William. A pluralistic universe: Hibbert lectures at Manchester College on the Present Situation in Philosophy. New York: Longmans, Green And Co., 1909.

JANKÉLÉVITCH, Vladimir. Henri Bergson. 3. ed. Paris: Presses Universitaires de France, 2011.

LAPOUJADE, David. Puissances du temps: Versions de Bergson. Paris: Les Éditions de Minuit, 2010.

PEARSON, Keith Ansell. Philosophy and the adventure of the virtual: Bergson and the time of life. London: Routledge, 2002.

PINTO, Débora Cristina Morato. Bergson e os dualismos. Trans/form/ação, São Paulo, v. , n. 27, p.79-91, jan. 2004.

PINTO, Débora Morato. Crítica do Negativo e Ontologia da Presença: a interpretação de Bergson segundo Bento Prado Junior. O Que nos Faz Pensar, Rio de Janeiro, v. 22, n. 01, p.23-48, nov. 2007. Disponível em: $<$ http://www.oquenosfazpensar.com/adm/uploads/artigo/critica_do_negativo_e_o ntologia_da_presenca:_a_interpretacao_de_bergson_segundo_bento_prado_junior 122_Critica_do_negativo_e_ontologia_da_presença.pdf $>$. Acesso em: 28 jun. 2016 . 
PRADO JUNIOR, Bento. Presença e campo transcendental: Consciência e negatividade na filosofia de Bergson. São Paulo: Editora da Universidade de São Paulo, 1989.

RIQUIER, Camille. Archéologie de Bergson: Temps et métaphysique. Paris: Presses Universitaires de France, 2009.

SARTRE, Jean-paul. L'imaginaire: Psychologie phénoménologique de l'imagination. Paris: Éditions Gallimard, 1986.

SOULEZ, Philippe; WORMS, Frédéric. Bergson. Paris: Presses Universitaires de France, 2002.

VIEILLARD-BARON, Jean-louis. Bergson et la religion. Revue Philosophique de La France Et de L'Étranger, Paris, v. 126, n. 4, p.505-516, abr. 2001.

WOLFF, Francis. Le temps comme concept hybride. Revue de Métaphysique Et de Morale, [s.1.], v. 72, n. 4, p.487-512, 2011. CAIRN. http://dx.doi.org/10.3917/rmm.114.0487.

WORMS, F. et al. Annales Bergsoniennes: Bergson, Deleuze et la phénoménologie. Paris: Presses Universitaires de France, 2004.

WORMS, Frédéric et al. Annales Bergsoniennes: L'évolution créatrice 19072007: épistémologie et métaphysique. Paris: Presses Universitaires de France, 2008 .

WORMS, Frédéric. Bergson ou les deux sens de la vie. 2. ed. Paris: Presses Universitaires de France, 2013.

WORMS, Frédéric. Introduction à Matière et mémoire de Bergson: Suivie d'une brève introduction aux autres livres de Bergson. Paris: Presses Universitaires de France, 2007.

WORMS, Frédéric. La philosophie en France au XXème siècle: Moments. Paris: Gallimard, 2009.

WORMS, Frédéric. Le vocabulaire de Bergson. Paris: Ellipses, 2000.

WORMS, Frédéric. La conscience ou la vie? Bergson entre phénoménologie et métaphysique. In: FRANÇOIS, Arnaud et al.Annales Bergsoniennes II: Bergson, Deleuze, la phénoménologie. Paris: Presses Universitaires de France, 2004. p. 191-206. 